PC-1-001 CGH 法で同定された食道癌での 20q コピー 数増加と標的候補遺伝子群の臨床病理学的検討 藤田佳史, 阪倉長平, 下村克己, 上田祐二, 系井啓純, 園 山輝久, 萩原明於, 山岸久一

(京都府立医科大学消化器外科)

【目的・方法】食道癌細胞株 9 種類と臨床検体 41 例を用い, CGH 法に て, 食道癌の染色体遺伝子診断に応用可能な病型特異的ゲノム異常を 検索した. さらに高頻度に認められた 20 番染色体長腕の標的候補遺 伝子として AIB1, BTAK, DcR3,E2F1について, 増幅及び発現を FISH 法及び半定量的 RT-PCR 法を用いて検討した. $20 \mathrm{q}$ 過剩の有無 及び各標的候補遺伝子増幅の有無と臨床病理学的因子を比較検討し た.結果・考察】臨床検体での染色体の過剩は 1q, 3q, 5p, 8q, 11 $\mathrm{q}, 14 \mathrm{q}, 20 \mathrm{q}, \mathrm{Xq}$ に, 久失は $3 \mathrm{p}, 4 \mathrm{p}, 4 \mathrm{q}, 9 \mathrm{p}, 18 \mathrm{q}, X \mathrm{p} に$ 高頻度に 認められた。 また, 細胞株と臨床検体各々において AIB1では, 11 \%, 4.9\%, BTAK では, $11 \%, 9.8 \%, \mathrm{DcR} 3$ では, $11 \%, 4.9 \%, \mathrm{E} 2$ $\mathrm{F} 1$ では，11\%，9.8\%の増幅を確認した. E2F1において細胞株で 33 $\%$, 臨床検体では $38 \%$ の高発現を認めた. 他の遺伝子でも同程度の頻 度で高発現を認めた. $20 \mathrm{q}$ 過剩の有無において, 深達度, リンパ節転 移, ステージに有意差を認め, BTAK と E2F1の増幅の有無において 予後に有意差を認めた。これら増幅及び高発現が認められた症例は, 早期に再発し死亡した. 以上の結果よりこれらの遺伝子群は食道癌の 悪性化に関与しており, 新しい予後因子となり得ると考えられた。

PC-1-002 食道多発癌症例の臨床病理学的検討 ; 粘膜切 除の見地から

熊谷洋一，河野辰幸，永井 鑑，岩井武尚

(東京医科歯科大学外科)

（はじめに）手術切除標本の検討を参考にしながら食道多発癌 の特徴を解明する. (対象と方法) 手術例は食道癌 274 例を対 象とし;このうち食道多発癌症例は 59 例 (21.53\%) 171 病巣 認めた。これを多発食道癌症例, 単発食道癌症例 (215 例) の 2 群にわけて検討した. 粘膜切除症例は食道癌 171 例, 198 病巣を対象とし, 多発食道癌は 33 例 $(18.7 \%) 71$ 病巣であっ た. (結果) 手術症例の検討では, 主病巣の深達度, Stage, リ ンパ節転移, 予後は 2 群間で有意差はなかった. 副病巣 112 例の検討では, 深達度は $\mathrm{m}$ 癌が $80 \%$ を占め, 大きさは平均 1.7 $\mathrm{cm}$ で, 副病巣の主病巣からの距離は平均 $2.1 \mathrm{~cm}$ であり, その 分布は, 主病巣の近傍が最も多かった. 重複癌の検討では, 多 発食道癌群で頭澒部重複癌が有意に多かった $(\mathrm{p}=0.046)$. 粘膜 切除症例では, 同時性食道多発癌は 16 例, 異時性多発癌は 17 例であった. 異時性多発癌の発生時期は平均 11.3 ヶ 月であり, 発生部位は異時性多発癌では初回切除部と同じ占拠部位に多 く見られた. (結語) 食道粘膜切除症例では, 初回切除部近傍と 頭顤部重複癌に特に注意を払って観察しなければならない.
PC-1-003 食道癌手術症例における反回神経周囲リンパ 節術中迅速診断法の比較検討とその意義 永谷史朗, 嶋田 裕, 李 志剛, 加賀野井純一, 前田賢人, 渡辺 剛, 今村正之

(京都大学腫瘍外科)

背景：胸部食道癌において反回神経周囲 LN (LN106rec) 転移の有無 と頚部 LN 転移には有意な相関が認められていることから, 近年 LN106 rec の術中迅速診断を施行し頝部 LNの転移予測が試みられている. 目 的：HE 染色 (HE), 免疫組織染色 (IHC), RT-PCR 法の 3 法による LN 106rec の術中迅速診断にて頝部郭清を決定する prospective な検討を行 い再発, 予後との関係を明らかにする. 方法：2001 年から 2002 年の食道 癌手術症例 18 例について LN106rec の術中迅速診断(HE, IHC, RT-PCR 法)を施行した. IHC は抗 cytokeratin 抗体を用い RT-PCR 法はRT 後 SCCmRNA を標的とした realtime PCR 法 (LightCycler 使用) にて行っ た. 3 法いずれかにて転移陽性の場合は全例頝部郭清を施行, いずれも陰 性であった症例では無作為に選択し顗部郭清を施行した. 結果：18 例中 LN106rec 転移陽性と診断されたのは 9 例, 転移陰性と診断されたのは 9 例であった. 前者 9 例全例に䅡部郭清を施行し 5 例が頚部 LN 転移陽性 (HE, RT-PCR 法), 後者 9 例中 3 例に頝部郭清を行ったが頝部 LN 転移 は認めなかった. 考察：LN106rec 転移陽性例では顤部郭清施行の妥当 性が確認された。また LN106rec 転移㓌性例についての罆部郭清省略の 妥当性は今後症例を重ね検討する必要があると考える.

\section{PC-1-004 食道腺癌に対する手術術式の検討}

塩崎 敦, 糸井啓純, 北村和也, 大辻英吾, 上田祐二, 園 山輝久, 萩原明於, 山岸久一

(京都府立医科大学消化器外科学教室)

【はじめに】食道腺癌は本邦では少なく術式選択には詥議が多い。我々は従 来，食道腺癌に対し扁平上皮癌手術に準じた方針を適応してきた．今回， 食道腺癌切除例の臨床病理学的所見より手術術式について検討した. (臨 床病理学的所見】 1983 年から 2002 年までの食道癌切除例は 296 例. 食道 腺癌は 10 例. 平均年齢 53.4 歳. 全て男性. 主占居部位: Mt1 例, Lt 4 例, Ae 5 例. 手術: 右開胸開腹 9 例, 左開胸開腹 1 例. 2 領域郭清 9 例, 左開 胸による中下部絴隔郭清 1 例. 再建: 胃管頝部吻合 6 例, 胸腔内吻合 4 例. 高, 中分化腺癌 6 例 (Barrett 腺癌 2 例), 低分化腺癌 4 例. 主占居部位別 転移リンパ節は Lt $\rightarrow 1$ 群 : \#110 (1 例), \#1 (1 例)，\#2 (1 例) 2 群：\# 106rec (1 例), \#108 (1 例), \#3 (3 例), \#7 (1 例) で, $\mathrm{Ae} \rightarrow 1$ 群: \# 1 (4 例), \#2 (1 例), \#3 (2 例) 2 群 : \#110 (3 例), \#111 (1 例), \# 7 (2例)，\#10 (1 例)，\#11 (3 例) 3 群: \#8a (3 例) 4 群: \#107 (2 例), \#16 (1 例). 【結果】1) 食道胃接合部癌は 5 例, Barrett 腺癌は 2 例 であった．2）胸腔内転移リンパ節の上限は Lt で\#106rec, Ae で\#107 であった. 3) Ae の腹腔内 3,4 群転移リンパ節には\# $8 \mathrm{a}$, \#16がみられた。 【考察】食道腺癌に対するリンパ節郭清から見た術式として占居部位 Lt では右開胸による胸腔内吻合に, Ae では左開胸開腹術に縮小できる. 
PC-1-005 右側大動脈弓に合併した胸部下部食道癌の手 術に対する検討

玉井秀政，系井啓純，北村和也，大辻英吾，上田祐二，園 山輝久, 萩原明於, 山岸久一

(京都府立医科大学消化器外科)

【緒言】右側大動脈弓は，一般剖検例の $0.1 \%$ に見られる比較的稀 な疾患であり,右側大動脈弓に合併した食道癌の切除報告例は, 非 常に稀である．右側大動脈弓に合併した胸部下部食道癌に対する 根治術式について，左開胸の有用性並びにその限界について検討 した. 【症例】46 歳, 男性. Lt:Ae, EGJにわたる 2 型食道癌. 胸部 CT で右側大動脈弓, 右下行大動脈を確認, 右側大動脈弓の中枢側 上り左総䅡動脈, 右総澒動脈, 右鎖骨下動脈の分岐を認め, 下行大 動脈の大動脈頽室より左鎖骨下動脈が異所性に分岐していた。 Stewart 分類 TypeIIA. 【手術】左第 6 肋間開胸開腹, 食道切除, 胸腹部リンパ節郭清, 横隔膜, 左肺下葉, 肝外側区域, 各々合併切 除とし，食道再建は胃管による胸腔内食道胃管吻合．左反回神経 は，大動脈憩室より異所性に分岐した左鎖骨下動脈と肺動脈との 間の動脈管索を前方より後方に反回しこれを温存しえた.【結語】 右側大動脈弓に合併した胸部下部食道癌症例に対し，右側大動脈 弓を確実に診断し，左開胸アプローチの選択で良好な視野を得ら れる.上縦隔において完全な郭清は困難であり, 上縦隔への放射線 照射及び術後化学療法の追加を考虑しなければならない.

PC-1-006 磁石吻合が有効であった食道癌術後吻合部狭 窄の一例

高木幸浩，木村 敦，竹村茂之，熟見靖彦

(熟見病院外科)

[目的］食道癌術後狭窄によるブジー困難症例に対して磁石 吻合を行い良好な結果を得たので報告する. [患者] 62 歳男 性, [主訴] 噮下困難, [現病歴] 平成 9 年 7 月に食道癌手術 (食道亜全摘胸壁後経路胃管再建)を受けたが, 術後縫合不全 による食道胃管吻合部狭窄を来し，8回のブジー拡張術を施 行されてきた. 平成 13 年 5 月, 水分の摂取困難となり, 治療 目的で精査を開始. [検査結果] 上部消化管造影検査では食道 胃側端吻合と同部の狭窄を確認, バリウム流出は食道下端が 盲端のため，やかん出口状であった.内視鏡による側端吻合 孔の同定は困難であった. [手術]ネオジム磁石による食道下 端部・胃管吻合を試みた。食道側にガイドつき磁石 $\mathrm{A}$ （自 作), 胃管側は胃切開によりガイドつき磁石 B(自作)を挿入. 透視下で磁石 A と B が引き合うまで近接させて手術終了. [術後]胸部 X-P で磁石 A, B 間の狭小化を経過観察, 12POD に造影検査で新たな吻合の完成を確認した。 [退院後経過]術 後 7 ヶ月経過したが, 狭窄傾向無し. [結語] 食道胃管吻合部 狭窄に対して胸腔内磁石吻合の有効症例を提示した。
PC-1-007 いわゆる早期食道メラノーマ (melanoma in situ）の二例

中野善之 ${ }^{1}$, 佐藤孝臣 ${ }^{1)}$, 三浦俊治 ${ }^{1}$, 天田憲利 ${ }^{1}$, 大橋洋 - '), 織井 崇"), 佐々木茂 ${ }^{11}$, 山口正明 ${ }^{21}$, 標葉隆三郎 ${ }^{3)}$

(仙台社会保険病院外科 ${ }^{1}$, 仙台社会保険病院臨床病理

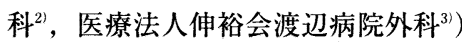

食道原発メラノーマは稀な疾患であり，食道新生物の約 $0.1 \%$ を占めるにすぎない. 食道メラノーマは食道粘膜のメラノサイト より発生し，早期から血行転移やリンパ節転移を起こす，その予 後は切除例の 5 年生存率が $4.2 \%$ と極めて不良である. 一方, 内 視鏡検査の進歩によりいわゆる早期食道メラノーマ (melanoma in situ）も発見されるようになってきた，我々は，食道及び食道 胃接合部に発生した進行性メラノーマの術前診断から開胸開腹 による手術を行い, 術後の病理診断で早期食道メラノーマと診断 された症例と, 術前より早期食道メラノーマと診断され食道抜去 術を行った症例を経験した. 現在, 進行性食道メラノーマに対し ては積極的に手術が行われているが, その長期生存例は非常に少 なく予後が覀い.一方, 早期食道メラノーマの手術報告は少なく, 組織分類及び組織分類に基づいた手術方針は確立していない. QOLの観点からも，転移のない早期食道メラノーマに対しては 食道抜去術で十分である可能性がある. 今後, 内視鏡技術の発達 により早期食道メラノーマの増加が考えられ，症例を積み重ね食 道メラノーマの組織分類及び治療方針の確立が必要と思われる.

PC-1-008 逆流性食道炎により形成されたと考えられた 胃粘膜下偽熄室穿孔の 1 例

廣田昌紀, 弓場健義, 福井雄一, 黄 泰平, 籾山卓哉, 武 田浩二, 山崎芳郎, 小林 晏, 上仲永純, 水口真二郎 (大阪厚生年金病院外科)

【症例】54 歳男性. B 型肝炎・逆流性食道炎にて内科受診中, 2001 年 12 月 19 日上腹部痛にて当院受診. 腹部 CTにて free air を認 め腹腔鏡下大網被覆術試行.【経過】術後上部消化管内視鏡検査に て門歯より $35 \mathrm{~cm}$ に0-IIc 病変を認め, 生検にて GroupV, 中分化 型扁平上皮癌の診断を得た。また食道胃接合部に胃噴門部小弯側 胃壁内の偽憩室へと連続する瘦孔を認めた. 上部消化管造影では 胃噴門部小弯側の胃壁内に偽媳室を認め, 腹部食道と胃噴門部に 瘦孔を形成していた. 2002 年 1 月 28 日食道抜去・頚部食道細径 胃管吻合 (胸骨後経路) 施行. 偽媳室は腹部食道及び食道胃接合部 より $1.5 \mathrm{~cm}, 4.5 \mathrm{~cm}$ の小弯側粘膜の計 3 箇所の瘦孔と交通してお り, 病理組織では食道粘膜下から胃漿膜下層に広がり, 内腔は肉芽 組織により置換されていた.【考察】逆流性食道炎による繰り返す 炎症のため食道粘膜下に形成された偽咊室が食道から胃槳膜下に 広がり,ここから胃穿孔が生じたものと考えられた. 逆流性食道炎 の合併症としては狭窄・出血・穿孔などがあるが, 本症例のよう な経過により胃穿孔を生じた報告例は過去報告例を検索しえた限 り認めず，非常に稀な 1 例と思われたのでここに報告する. 


\section{PC-1-009 迷入茦より発生した食道腺癌の 1 例}

森谷 洋 $^{11}$, 松谷英樹 ${ }^{11}$, 久留島徹大 ${ }^{11}$, 鈴木伸作 ${ }^{11}$, 落合 浩平 ${ }^{1)}$ ，小澤正則 ${ }^{11}$ ，下山則彦 ${ }^{21}$ ，石舘卓三 ${ }^{2)}$

(市立函館病院外科 ${ }^{12}$, 市立函館病院病理研究検査科 ${ }^{21}$ )

食道迷入荤の癌化は極めて稀れである.われわれは食道粘 膜下発育を呈し HeinrichII 型食道迷入腪から移行像の確認さ れた腺癌の 1 例を経験したので報告する.

症例は 64 才男性. 平成 8 年 7 月初回入院. 胸部下部食道に 径 $6 \mathrm{~cm}$ の狭窄を認めるが粘膜に病変はなく開胸試切で腺癌 と診断された． $5 \mathrm{FU}$ とCDDPによる化学療法で症状は改善 し, 平成 9 年 2 月退院したが, 平成 10 年 3 月再び燕下障害が 高度となり入院した. 今回の病変は前回の狭窄部位の再発に 加えて $6 \mathrm{~cm}$ 口側にも狭窄がみられ, 粘膜面の顆粒状の隆起性 病変が出現し生検で腺癌と診断された. QOL 改善のための姑 息術式として同年 5 月食道抜去術を施行し，経過良好で退院 した. 切除標本では食道胃接合部に接した下部食道に管外性 発育を示す径 $2 \mathrm{~cm}$ の全周性腫瘍を認め，これより $6 \mathrm{~cm}$ 口側 にも同様の腫瘍が認められた，病理組織学的には下部食道の 主病巣は粘膜下に発育し, 筋層に浸潤する管状腺癌であった. さらに病巣内には HeinrichII 型の迷入荤組織がみられ癌との 移行像が確認された， 口側病変は壁内転移と判断された.

PC-1-010 尋常性天疮瘡に合併した食道癌の 1 例一天疮 瘡抗原・抗体価を指標とした治療一

高橋 収, 奥芝俊一, 武山 聡, 北城秀司, 川原田陽, 加 地苗人，平野 聡，森川利昭，近藤 哲，加藤紘之 (北海道大学大学院医学研究科癌医学専攻癌制御医学講 座腫瘍外科学分野)

(目的) 尋常性天疱癐は表皮内水疮を形成するる自己免疫疾患で，他 の悪性腫瘍との合併例が多数報告されている.今回, 尋常性天疮瘡 に合併した食道癌の 1 例を経験したので報告する. (症例) 症例は 71 歳, 男性. 尋常性天疮瘡の診断で皮虐科にて follow 中, 全身悪 性腫瘍検索にて食道癌（2c，SM2）と診断された．皮疹の MRSA 感染のほか, 免疫不全準備状態にあること, CT・PETにて明らか なリンパ節・遠隔転移を認めないことから非開胸食道抜去術を施 行した. 食道断端粘膜は浮腫状で水疮を形成しており,吻合部の血 流低下・脆弱化を懸念し手綘い吻合を施行した，病理検査にて扁 平上皮癌の所見以外に食道全体に及ぶ粘膜基底層直上での水疮形 成を認め食道天疮瘡と診断した. 術後から熱発が持続したが明ら かな炎症の focus を認めず，天疮㾑の悪化によるものと判断しス テロイド治療を開始したところ, 症状は劇的に改善した. (結語)食 道天疱瘡を合併する手術では，浮腫状粘膜はわずかな機械刺激で 容易に剥離するため, 慎重な手縫い吻合が必要である. また, 術後 に天疮瘡とともに全身状態が悪化した場合，天疮瘡抗原・抗体価 を指標としてステロイド使用時期を検討することが有効である。
PC-1-011 胸部食道癌根治術後再発症例の臨床病理学的 検討と再発治療について

松木 淳, 中川 悟, 西巻 正, 池田義之, 金子耕司, 田 辺 匡，本間英之，大橋 学，神田達夫，畠山勝義

(新潟大学大学院消化器 - 一般外科学分野)

胸部食道癌は 3 領域郭清の導入により予後の向上が得られて いるが，一方で再発症例も多い. 治療成績を向上させるために は, 再発症例の特徵を明らかにし, 適切な治療を行うことが重要 である. 本研究では, 1986 年 4 月〜1999 年 12 月までに胸部食道 癌にて 3 領域郭清を伴う食道切除術を施行し R0 と判断された 145 例を対症とし, 深達度, 大きさ, 局在, 組織分化度, リンパ 節転移, 壁内転移, ly, v, 術後療法, 進行度, 術後加療の有無 と再発の関係, 再発後加療と予後の関係について検討した。結 果, 再発 59 例 $(24.6 \%)$ では, 非再発例と比較して, 有意に深達 度が媣く, リンパ節転移, 壁内転移, ly +と $\mathrm{v}+$ が多く認められ， より進行度の高いものが多かった. 術後加療の有無には差は認 められなかった. 多変量解析では, リンパ節転移, 壁内転移と深 達度が独立した再発危険因子であった. 再発形式は, リンパ行性 が 26 例, 血行性が 20 例と多数を占めた. 再発例の経過は, 再発 後治療施行群 37 例（現在生存中 10 例を含む）の再発後の MST が，再発後未治療群 13 例の MST (1ヶ月)より有意に長かった. 再発症例に対する適切な治療により延命効果が期待される.

PC-1-012 多数のリンパ節転移を伴う N4 進行食道表在 癌の 2 例：治療戦略の考察

鍋谷圭宏"，松原久裕"，岡住慎一"1)，島田英昭"，舟波 裕 ${ }^{1}$, 白鳥 享", 織田暁寿 ${ }^{11}$, 宮崎信一"1), 神津照雄 ${ }^{2}$, 落合武徳" (千葉大学大学院先端応用外科 ${ }^{1}$, 千葉大学医学部附属病 院光学医療診療部 ${ }^{21}$ )

リンパ節転移多数と診断され，異なる治療法を選択した Tlb 食道 癌の 2 例を経験したので, 治療戦略を考察した. (症例 1】64 歳, 男性. Lt $6 \mathrm{~cm}, 0-\mathrm{IIc}+\mathrm{IIa}$, 生検 mod. diff. SCC, sml, \#101R · 104RL · 106 $\mathrm{recR} \cdot 106 \mathrm{tbL} \cdot 108$ に計 7 個の転移ありと診断（T1bN4M0：Stage IVa). 5-FU + CDDP + 45Gy 照射の neoadjuvant chemoradiotherapy を先行し，原発巣 $\mathrm{CR} ， \# 101 \mathrm{R}$ に転移残存が疑われ PR と判定. 3 領域郭清根治手術を施行 (根治度 A) したところ, 原発巣・郭清リン パ節とも grade3で癌細胞を認めず (Ra・Ch-pTXN0M0), 現在無再 発生存中.【症例 2】57 歳, 男性. Mt 4cm, 0-IIa + IIc, 生検 keratinizing SCC, sm1, \#110・7・9・11・16a2-b1 に計 7 個以上の転移あり と診断（T1bN4M0：Stage IVa）. 患者の希望で大動脈周囲を含む 3 領域郭清根治手術を先行 (根治度 B) したが, sm3, ly3, v1, pIM1, Inf $\beta$, 3 領域に計 68 個のリシパ節転移陽性 (pTlbN4M0：pStage IVa)。術 後 1 ヶ月で\# $16 \mathrm{bl}$ に再発し, 化学療法を絽り返すも, 維隔・頚部に リンパ節再発進行中. (考察】T1b 食道癌でも，転移リンパ節 4-5 個以 上と診断されれば lymphatic disseminationの可能性があり, neoadjuvant CRT が有用な治寮選択肢の一つになると思われる。 
PC-1-013 Nedaplatin/5FU 及び Radiation 併用療法が 著効した切除不能および再発食道癌の 2 症例

久保秀文, 中尾光宏, 重田匡利, 吉田 晋, 井口智宏, 宮 原 誠, 河内康博, 長谷川博康, 宮下 洋 （社会保険徳山中央病院）

今回, 我々は放射線照射併用化学療法が有効であった食道癌 2 例を 経験したので報告する. 症例 161 歳男性. 燕下困難, 下血を主訴に来 院. 画像にて T4, N2, M0： stage4a と診断した. down stage を期して 計 $40 \mathrm{~Gy}$ の放射線照射と Nedaplatin (以下 NDP) : 10mg, $5 \mathrm{FU}: 500$ $\mathrm{mg} /$ body/day 5 連日投与 2 日休薬/1 クールとして計 6 クール投 与した. 臨床症状は劇的に改善し; 画像検査にて効果判定 CR とした. また治療前に高值であったSCCマーカーも正常化した. その後患者, 家族ともに手術を拒否した為, NDP：20mg, $5 \mathrm{FU}: 750 \mathrm{mg} /$ body $/ 2$ $\mathrm{W}$ を外来にて計 10 回投与した. 治療開始よりほほ 1 年 8 ケ月経過す る現在も CR を継続している. 症例 270 歳 男性. Mt 部の食道癌に対 し D1 郭清伴う食道要全摘術を行った. 最終診断は T1b, pN0, M0, IM $0, \mathrm{R} 0$, stageI, 組織型は中分化型扁平上皮癌).術後 10 ヶ月して喉頭不 快感出現し頚部 MRI 検査で右側下咽頭から梨状窩にかけて存在する 腫瘤が認められた。総量 40Gy の放射線照射と NDP, $5 \mathrm{FU}$ ：前記同量 を 5 クール投与した. 治療後の頝部 MRI 検査で CR と判定した. その 後 NDP : $20 \mathrm{mg}, 5 \mathrm{FU}: 750 \mathrm{mg} / \mathrm{body} / 2 \mathrm{~W}$ を外来にて計 7 回投与した. 術後 2 年 3 ヶ月経過する現在, 再発徴候なく健在である.

PC-1-014 食道原 発 neuroendocrine carcinoma（nonsmall cell type）の 1 例

犬塚和德"，藤崎真人 ${ }^{11}$ ，高橋孝行 ${ }^{1}$ ，平畑 忍 ${ }^{11}$ ，前田 大 ${ }^{11}$ ， 和田德昭",，松本昌久 ${ }^{1}$, 亀井秀策"), 船橋益夫 ${ }^{1)}$, 清水和彦 ${ }^{2}$ (足利赤十字病院外科 ${ }^{1}$, 足利赤十字病院病理 ${ }^{2}$ )

症例は 68 歳, 男性. 主訴は食後つかえ感. 平成 13 年 8 月より主 訴出現, 近医受診し内視鏡にて胸部中部食道に腫湯を認め, 生検で は group5（scc）であったため，当科受診となった，上部消化管内 視鏡で上切歯列より $25 \sim 30 \mathrm{~cm} に 2$ 型腫瘍とその $1 \mathrm{~cm}$ 口側に SMT 認めた. 食道造影検査では胸部中部食道前壁に $4 \times 2 \mathrm{~cm}$ の 潰瘍性病変, その口側に $1 \mathrm{~cm}$ 大の透亮像を認めた。潰瘍性病変の生 検で small cell carcinoma より.も大きい腫瘍細胞のロゼット形成が みられ, neuroendocrine carcinoma を疑った. その他に原発巣を疑 う所見はなかったことから根治術として, 右開胸開腹食道垔全摘, D2, 胸骨後胃管吻合術を施行した. 術後病理診断で $38 \times 27 \mathrm{~mm}$ の 3 型腫瘍は, 光䫓では腫瘍の大部分は粘膜下層に存在し, 充実性索状 に増殖し，ロゼット形成の目立つ腫瘍であり，クロモグラニン A 染色では陽性, 電影にて腫瘍細胞内に神経内分泌顆粒が散見され た. 本腫瘍は食道原発 neuroendocrine carcinoma（non-small cell type）と診断した. mp, lyl, v1, n2 で組織学的進行度は stageIII であった. また, 口側の SMT は GIST, smooth muscle type と診断 された. 食道原発の neuroendocrine carcinoma は非常に稀である.
PC-1-015 経食道裂孔穴プローチにより手術を施行した 食道破裂の 3 症例

大橋 学 ${ }^{11}$, 西巻 正 $^{11}$, 神田達夫 ${ }^{11}$, 中川 悟1), 小野一 $之^{11}$, 多田哲也 ${ }^{2)}$, 鈴木 力 ${ }^{1)}$, 畠山勝義 ${ }^{11}$

(新潟大学大学院消化器 - 一般外科 ${ }^{1}$, 立川総合病院外 科 ${ }^{2)}$ )

食道破裂に対する外科的治療は開胸手術が原則で, 場 合によっては開腹を加えなくてはならず，過大侵襲の手 術となり得る. 我々は, 開腹のみの経食道裂孔アプローチ による手術で良好な結果を得ているので報告する.【症例 1】 45 歳, 男性. 特発生食道破裂と診断され, 開腹で横隔 膜切開の下, 破裂部の縫合閉鎖と, 胃壁による補強, ドレ ナージが行われた：術後 83 病日に退院した.【症例 2】 67 歳; 男性. 魚骨による下部食道穿孔と診断され, 経食道裂 孔アプローチで穿孔部の縫合閉鎖と, 大網被覆, ドレナー ジが行われた。術後 85 病日に退院した.【症例 3】54 歳, 男性. 特発性食道破裂と診断され, 経食道裂孔アプローチ で, 破裂部の縫合閉鎖と, 大網被覆, ドレナージが行われ た. 術後 31 病日に退院した.【考察】食道破裂に対する経 食道裂孔アプローチによる手術は，低侵襲で，下縦隔；両 側胸腔の観察が可能であり，胃あるいは大網による被覆 が容易であることなどから，下部食道破裂に有用な術式 である.

PC-1-016 きわめてまれな食道原発 GIST の 1 切除例

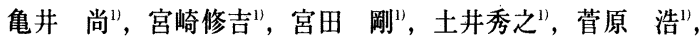
森 隆弘 ${ }^{1}$, 阿部啓二1), 市川宏文 ${ }^{11}$, 高橋雄大 ${ }^{11}$, 笹野公伸 ${ }^{21}$ (東北大学医学部先進外科 ${ }^{1}$, 東北大学医学部第 2 病 理 ${ }^{2)}$

【はじめに】消化管原発の間葉系腫瘍の多くは Gastrointestinal Stromal Tumor (GIST) なる概念で包括され，胃や小腸由来の GIST に関する知見が集積されてきているが，食道原発の GIST は非常に稀で世界でも数例の報告しかない. 今回, 食道原発 GIST の 1 症例を経験し, 治瘉切除し得たので報告する.【症例】 72 才の 女性. 1990 年に検診で食道の腫瘤性病変を指摘され, 他院で食道 平滑筋腫として経過観察されていた. 2001 年 8 月,CT で腫場の増 大を認め，9月にCT ガイド下に縦隔生検を施行したところ， GIST を疑われ, 手術目的に当科紹介となった. 内視鏡では門歯列 より 28 から $34 \mathrm{~cm}$ の食道左壁に粘膜下腫瘍による圧排を認め, $\mathrm{CT}$ では胸部下部食道より左胸腔へ突出する径 $7 \times 9 \times 5 \mathrm{~cm}$ の腫瘤 を認めたが，食道との境界は不明暸であった。【手術所見】腫瘍は， 食道からダンベル状に左胸腔へ広がっていたが，周囲への浸潤は なかった. 腫場とともに下部食道を切除し, 有茎空腸間置により再 建した. 【病理】腫瘍内は主に紡錘形細胞の束状増殖を認め,免疫染 色では c-kit $(+)$, CD34 (+), vimentin (+)であったが, SMA (-), S-100(-), CEA(-)で, GIST の診断と矛盾しなかった. 
PC-1-017 下咽頭癌術後吻合部難治性瘦孔に対し, 内視 鏡下シアノアクリレート治療が有効であった一例 尾形高士, 佐藤 滋, 高木 融, 逢坂由昭, 篠原玄夫, 岡 田了祐, 立花慎吾, 飯岡佳彦, 青木達哉, 小柳泰久 (東京医科大学外科学第三講座)

【はじめに】我々は下咽頭癌術後吻合部瘦孔に対し, 生体 接着凨である Ethyl-2-cyanoacrylate (以下 ECA)を用いた 内視鏡的㾇孔閉鎖術を試み，良好な結果を得たので報告 する. 【症例】 68 歳男性. 主訴は圜下時つかえ感. 精查にて 下咽頭癌と食道癌が発見された。 下咽頭癌は cT4NOM0Stage4, 食道癌はcT1aN0M0-Stage0 と診断した. Taxotel, CDDP, 5-FUを用いた化学療法を 2 コース施行 後, 食道癌に対し内視鏡的粘膜切除術, 下咽頭癌に対し咽 頭喉頭全摘, 頚部食道切除, 遊離空腸再建, 両側䅡部郭清 術を施行した. 術後造影にて, 咽頭遊離空腸吻合部前壁よ り造影剂の漏出を認めた. その後 5 週間の絶食期間をお いたが瘦孔が閉鎖しなかったため, 内視鏡下に瘦孔入口 部を確認し，同部位に散布チューブを挿入，引き抜き法に て ECA2ml を散布した. その後瘦孔は閉鎖し, 経過良好に て第 86 病日に退院となった.【まとめ】ECA を用いた内視 鏡的瘦孔閉鎖術は, 保存的治療で改善しない術後瘦孔に も有効な治療法であると考えられた.

\section{PC-1-018 乳癌食道転移の 2 例}

小池聖彦, 秋山清次, 中山裕史, 今澤正彦, 藤竹信一, 日 比健志, 小寺泰弘, 今井恒夫, 伊藤勝基, 中尾昭公 (名古屋大学医学部)

極めてまれな乳癌食道転移 2 例を経験したので文献的考察を 加え報告する. 症例 1) 72 才女性. S53 年左乳癌で定型的乳房切 断術施行. $\mathrm{H} 12$ 年上旬より䓵下時つかえ感を自覚. H13 年 4 月 24 日の GIF で異常指摘されず．5月 25 日 GIF 再検にて歯列 30-35 $\mathrm{cm}$ にヨード不染を伴わない全周性狭窄が存在した. 組織診断で 悪性像は確認できず, 最終的な診断に 2 回再検を要した. 8 月 10 日右開胸食道要全摘術を施行. 組織は乳癌標本に類似し免染で ER (+) であり，乳癌食道転移と診断した。症例 2) 52 才女性 $\mathrm{H} 3$ 年右乳癌で定型的乳房切断術施行. H13 年 1 月から䓵下困難 感出現，8月 21 日 GIF を施行したが異常指摘されず. 11 月 16 日 GIF 再検にて下部食道にヨード不染のない全周性狭窄を認

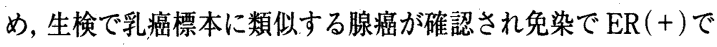
あった。他臟器転移も認められたため, 食道狭窄に対してはステ ントを留置した。 食道病変は粘膜下に発育し粘膜面の異常がな くGIFで見落とされる危険があり, 腫場組織の採取も困難であ り確定診断が難しい: 治療は対症療法が主体となるが, 転移が食 道のみで切除可能な症例では切除を試みるべきである.
PC-1-019 放射線治療の既往がある食道, 気管重複癌の 一治療経験一術式の工夫を中心に一

長谷龍之介, 奥芝俊一, 北城秀司, 川原田陽, 七戸俊明, 加地苗人, 平野 聡, 森川利昭, 近藤 哲, 加藤紘之 (北海道大学腫瘍外科学)

はじめに: 今回我々は稀な食道, 気管重複癌症例の治療経験を 術式の工夫とともに報告する. 症例：66歳, 男性. 主訴：血痰. 現病歴: 平成 9 年 6 月喉頭癌, 食道癌に対し放射線治療を施行. 平成 10 年 1 月遗残食道癌再発し, 胸部食道全摘術, 右結腸によ る再建を施行した. 平成 13 年 3 月血疢出現し当科受診した. 術 前検查所見：BFで声門下 $1 \mathrm{~cm} \sim 4 \mathrm{~cm}$ にカリフラワー状隆起病 変を認め, GIFでは䅡部食道に広範囲のルゴール不染帯を認め た. 手術：2001 年 5 月 23 日下咽頭, 唵頭, 頚部気管, 頝部食道 切除, 遊離空腸再建, 両㑡大胸筋膜皮弁, 永久気管瘦造設, 植皮 を施行した: 放射線治療後であること, 気管皮虙吻合部に緊張が かかること, 食道合併切除のため気管断端血流が少ないことか ら気管皮虙縫合不全の可能性が考えられた. 気管左甲状腺付着 部の温存, 大胸筋膜皮弁を用いた吻合により吻合部の緊張を避 け, 気管瘦を造設した. 病理組織学的検查 : 食道, 気管とも中分 化型扁平上皮癌であったが病変間の連続性はなく同時性重複癌 と診断した：まとめ：放射線治療後の high risk 症例に対し, 術 式の工夫により安全に碩部気管瘦を造設し得た。

PC-1-020 食道癌術後再建胃管に急性出血性潰瘍を形成 し, 救命し得た一例

吉岡慎一, 辻仲利政, 平尾素宏, 藤谷和正, 武田 裕, 辛 栄成, 三嶋秀行, 沢村敏郎, 蓮池康德, 西庄 勇 (国立大阪病院外科)

【はじめに】食道癌術後早期に再建胃管に Dieulafoy 溃瘍を形成 し, 出血性ショックを起こしたものの, 救命し得た症例を経験し たので, 報告する. [症例]症例は 47 歳男性. 検診指摘, 食道亜 全摘・胸腔内胃管再建 $\cdot 2$ 領域郭清術を施行. 術後 9 日目に, 腸 㾯より大量出血と吐血が出現, 出血性ショックの状態となった。 緊急内視鏡にて, 胃管内を確認したが, 出血点は確認不能. 次に, 腹部血管造影にて責任血管は同定できたが, 止血不能. 続いて開 腹にて責任動脈である右胃動脈の分枝を結禁,一時止血したが, 翌日, 再び大量出血. 再度開腹にて胃管切開し血餅を取り除き, 内視鏡にて胃管内を検索, 前庭部にDieulafoy 潰瘍を認めた。内 視鏡的にエタノールを注入, クリッピングし, 止血を確認した。 その後, 肺炎を併発したが, 術後 49 日目に退院した. [考察]食 道癌術後の胃管潰瘍には, 急性病変と慢性病変が存在し, 慢性潰 瘍は報告は少ないが, 出血・穿孔・穿通を生じて致死的となる ことがある. 急性潰瘍では出血が問題となり, 治療に難啮し, 胃 管全摘が必要となることがある. 本例では, 術中内視鏡操作によ り胃管の温存が可能であり, 救命につながったと考えられた. 
PC-1-021 治療量の術前化学放射線療法を併用した T4 StageIII 食道癌 3 切除症例の臨床病理学的検討 吉川健治, 山口拓也, 平林邦昭

\section{(耳原総合病院外科)}

目的：治療量の術前化学放射線療法を施行後に食道癌根治術を 施行された T4 StageIII 食道癌 3 症例を臨床病理学的に検討し た. 対象：症例 1.69 歳 男性 Ut T4 (気管) N0M0 症例 2.65 歳 女性 MtLt T4 (大動脈) N1M0 症例 3.68 歳 男性 $\mathrm{Mt}$ T4 (気管) NOM0 方法：1. 切除標本から術前の治療量の術前化 学放射線療法の効果を検討した. 治療効果の判定は食道癌取り 扱い規約に準じた. 2 . 各症例の術後生存期間,術後合併症を呈示 した. 結果：1. 切除標本の検索では症例 No. 1, No. 2 は Grade 2. 症例 No. 3 は Grade3 の効果が認められた. 2. 平均観察期間は 23 ヶ月であり, 生存期間は 症例 No. 1 が 28 ケ月再発死亡 No. 2 が 27 ヶ月無再発生存中 No. 3 が 14 ヶ月死亡 (原因不詳) と 3 例中 2 例が 2 年以上生存した. 術後合併症は症例 1 が術後 肺炎にて術後 7 日間の人工呼吸管理を必要とし, 症例 2 が術後 膿胸にてドレナージ術を必要とした。結語：治療量の術前化学 放射線療法を併用した食道癌根治術は T4 StageIII 食道癌の生 存期間の延長に寄与する可能性が示唆されが術後管理に際して は術後早期の感染症対策を厳密にする必要がある.

PC-1-022 H. pylori を含めた胃管癌の臨床病理学的検討 と本邦報告胃管癌症例

木勢佳史 ${ }^{1}$, 鬼島 宏 ${ }^{2}$, 島田英雄 ${ }^{11}$, 剣持孝弘 ${ }^{1}$, 田仲 曜 ${ }^{1}$, 千野 修 ${ }^{11}$, 幕内博康 ${ }^{1}$

(東海大学消化器外科 ${ }^{11}$, 東海大学病院病理学 ${ }^{21}$ )

目的：当院での食道癌術後胃管癌について臨床病理学的検 討を行ない, H. pylori の有無について検討した. 現在まで の本邦報告例についても臨床病理学的に検討した. 方法： 1991 年から 2000 年までで当科において認めた胃管癌は 8 例であった. 臨床病理学的特徴を解析し, 胃管の生検組織で H. pylori, intestinal metaplasia の有無を検討した。また, 本邦報告例についても臨床病理学的特徽を解析した. 結 果：経験例の $50 \%$ は胃管遠位に発生した. 2 症例以外は全 て早期に発見され内視鏡的治療を施行した。胃管よりH. pylori は認めなかったが, 全ての症例で様々な grade の intestinal metaplasia を認めた。本邦胃管癌報告例は年々増 加している. 早期癌は 0-IIa, 0-IIc が, 進行癌は type2, type 3 が多かった．胸骨前胃管再建で腫瘤触知にて患者自身が 発見する例が多い. 結語：早期発見すれば内視鏡的に治療 できるため，食道癌術後長期にわたる内視鏡フォローは大 切である.われわれの解析では胃管癌と H. pylori の関係は 認めなかったが, さらに詳細な検索を要する.
PC-1-023 胸部上部食道癌症例におけるリンパ節微小転 移の検討

主藤朝也, 藤田博正, 藤井輝彦, 末吉 晋, 田中寿明, 唐 宇飛，笹原弘子，的野 吾，山名秀明，白水和雄 (久留米大学医学部外科学教室)

[目的]胸部上部食道癌におけるリンパ節微小転移と臨床病理学 的因子との関連性, 頚部郭清の必要性, 微小転移が再発予後の指 標たるかを検討する. [方法] 1986 年から 2000 年まで当教室で 施行された Ut 症例 18 例を対象とし，免疫染色 (AE1/AE3)を 行い, 微小転移の有無を検索, 臨床病理学的因子との関連につい て検討した. [結果] 18 例中病理診断で転移無しと診断されたの は 5 例, その内 4 例に微小転移を認めた. 微小転移は 12 個のリ ンパ節で観察，10 個は顤部，反回神経周囲 (No.101, 102, 104, $106 \mathrm{rec}$ ) で，2 個は腹部（No，2）に認めた．転移リンパ節部位 には一定の傾向は認めず, 腫瘍型, 肉眼型, 分化度, 腫瘍浸潤形 式, 脈管侵襲, と微小転移との関係についても明確な関連性は認 めなかった，微小転移を認めなかった症例と微小転移を認めた 症例とで生存率に有意差は認めなかった. [考察] 抗サイトケラ チン抗体による免疫染色は. 微小転移を検出する方法として有 用である. Ut 症例での頝部リンパ節郭清の必要性が再確認され た. しかし, Ut 症例においてリンパ節微小転移は予後や再発予 測の指標には有用でないことが示唆された.

PC-1-024 食道癌における cDNA チップと蛋白チップ を用いた遺伝子・蛋白同時解析の試み

姜 貴嗣, 嶋田 裕, 川部 篤, 加賀野井純一, 佐藤史顕, 前田賢人，山崎誠二，今村正之 (京都大学腫瘍外科)

く緒言＞食道癌において cDNA chip と protein chip を用 いて遺伝子発現と蛋白発現の同時モニタリングの可能性 を検討する. <方法 $>A$ A) 食道癌組織 $(\mathrm{LN}(+) 10$ 例, (-) 10 例), 細胞株 SUm/c, HSA/c を cDNA microarray 解析 に用いた.リンパ節転移責任遺伝子として抽出された遺伝 子をもとに症例ごとにリンパ節転移指数（LMI）を算出し た. B) LN (+) 3 例と食道正常組織を protein chip 解析に 用いた。（結果>1） 20 個のリンパ節転移責任遺伝子を同 定した. 2) LN (+)，(一) 症例は 2 つのグループに分かれ た. 3) $\mathrm{SUm} / \mathrm{c}, \mathrm{HSA} / \mathrm{c}$ は LN $(+)$ 群に分類された。 4) 新 たに追加した 4 例（LN (+) 2 例，(-) 2 例）は 3 例が予 想された群に分類された. 5) 蛋白発現プロファイルは食道 正常組織と食道癌組織で著明に異なっていた. 6)遺伝子発 現と蛋白発現を同時に対比できるものもあるが, 発現は必 ずしも一致していなかった.く結語＞1) LMI 高値の症例は LN（+）である可能性が高い，2）将来遺伝子発現と蛋白 発現は同時にモニタリングできる可能性がある. 
PC-1-025 食道癌の Sentinel Node Navigation surgery の可能性について

瀧川譲治, 上之園芳一, 東 泰志, 中野静雄, 夏越祥次, 馬場政道, 愛甲 孝

（鹿児島大学医学部第 1 外科）

【目的】今回，食道癌において Sentinel Node Concept が成 立する可能性について検討した.【方法】対象は深達度 T 1-T3 まで食道癌 34 症例で, 手術前日に $99 \mathrm{mTc}$-Tincolloid $(6 \mathrm{mCi})$ を内視鏡下に注入した，注入 1 時間後に $\mathrm{lym}$ phoscintigraphy の撮像, 術中は hot node の検索, 術中迅 速診による病理学的検索を行った.リンパ節転移診断は HE 染色と Cytokeratin 染色を行った.【結果】表在癌 13 例では HE 陽性 4 例, Cytokeratin による微小転移陽性 1 例であり，すべて hot node であった，T2-3 症例では HE 染色による転移陽性の 16 例中 2 例に hot node が指摘不 能, 7 例が hot node と不一致であった. 術前照射化学療法 の 5 例中 2 例に hot node が指摘不能, hot node が描出 3 例中 2 例に転移を認めたが hot node とは不一致であっ た【結語】食道表在癌において SentinelNode Concept は 成立する可能性がある. 現時点で T2 以深例は Sentinel Node NavigationSurgery の適応にはなりえないと考えら れる.

PC-1-026 食道癌術後のチューブ栄養瘦が原因の合併症 の検討

吉岡泰彦, 藤川正博, 藤井 眞, 江本 節, 前田庄平, 仲 至永, 小牧孝充, 小田知文, 安達偉器, 吉川 澄 (大阪労災病院外科)

【緒言】食道癌手術時に造設するチューブ栄養㾇は, 遠隔期も含め, 生理的な栄養補給経路として有用であるが, 合併症も存在する.当 院での食道癌手術症例について，チューブ栄養瘻および瘦跡が原 因である合併症について検討した.【対象】1991 年〜2000 年の食道 覀全摘・胃管再建・頸部吻合症例 108 例について検討した. 胃管 からのチューブ栄養瘻造設例が 14 例, チューブ空腸瘦造設例が 50 例, 栄養瘦非造設例が 44 例であった.【結果】胃管からの症例で は, 1 例が周術期にチューブ挿入部が大きくカッティングし, 縦隔 炎にて死亡した. 空腸瘦症例では, 腸閉塞を 4 例に認めた. 発症時 期は術後 3 ヶ月, 6 ケ月, 3 年, 5 年であった. 1 例が瘉着, 3 例が 内へルニアが原因であった. 全例手術にて軽快した: 非造設症例で は腹部合併症は認めなかった.【考察】空腸瘦による腸閉塞につい ての諸家の報告における予防策は空腸の腹壁への広い固定等であ るが, 当院の症例では内ヘルニアが主であり, 不十分と考えた. 現 在は，空腸瘦造設時には Treitz 靯帯から腹壁に最短距離（約 15 $\mathrm{cm}$ ) で挙上し, 腹壁固定の上に結腸間膜への挙上空腸の固定も行 い, 空腸瘻の頭側に小腸が入り込まないよう工夫している.
PC-1-027 肺穿通胸部が食道癌に対し食道肺合併切除・ 2 期的食道再建が有効であった 3 例 西澤 聡, 大杉治司, 高田信康, 竹村雅至, 李 栄柱, 上 野正勝, 田中芳憲, 福原研一朗, 藤原有史, 木下博明 (大阪市立大学医学部外科学第 2 教室)

(症例 1) 56 歳男性, 昭和 60 年 11 月 24 日, 嚥下困難を自覚, 食道癌と診断され当科入院. 入院時発熱・咳嫩を認め, 右肺 下葉への穿通による肺化膿症と診断し，1月 31 日胸部食道 覀全摘・右肺下葉切除・食道外瘦・胃瘻造設術および 83 日 後に胸骨後胃管再建術 - 胃瘦造設術を施行. 食道切除より 223 日に誤嚥性肺炎にて死亡した. (症例 2) 58 歳男性, 平成 8 年 8 月 22 日嬹下困難と発熱より, 食道癌の右肺中下葉へ の穿通による肺化膿症と診断され入院. 8 月 23 日胸部食道 垔全摘・右肺中下葉切除・食道外瘦造設術および 80 日後に 胸骨後胃管再建術を施行した。術後 204 日に縦隔リンパ節転 移再発にて死亡した。 (症例 3) 59 歳男性, 平成 12 年 10 月 30 日食道癌と診断され, 当科入院. 11 月 11 日発熱が出現し, 右肺下葉への穿通による肺化膿症と診断し，11月 14 日開胸 下食道要全摘術・右肺下葉合併切除・食道外㾇造設術およ び 30 日後に胸壁前胃管再建術を施行. 現在も再発なく健在 である. (まとめ) 食道癌肺穿通による肺化膿症の 3 例に, 2 期的切除再建により安全に術後管理を行い得た。

PC-1-028 1 年以上生存した食道癌術後再発例の検討

桑原史郎, 片柳憲雄, 大谷哲也, 山本睦生, 斎藤英樹, 藍 澤 修

（新潟市民病院外科）

【目的】再発後長期生存例の特徴を明らかにする.

【対象・方法】 R0 手術後再発例 106 例を再発後長期生存群（1 年以上生存：A 群), 短期生存群 (1 年以内死亡：B 群)に分け両 群の比較検討を行なった.

【結果】 A 群の内訳：A 群は 13 例 (12\%), 頚部食道癌：胸部食 道癌：腹部食道癌 $=4: 9: 0$, StageI $:$ II $:$ III $:$ IV $=4: 3: 1 ：$ 5 , 再発後生存期間は 566 2831 日, 平均 $1134 \pm 1164$ 日であっ た. $\mathrm{A}$ 群と B 群の比較：T 因子, 転移個数, 根治度は両群間に差 を認めなかった，A 群では N1 以下，StageII 以下，頝部食道癌 の頻度が有意に高かった（A 群 vsB 群 =8 例 $(62 \%)$ vs23 例 (24 $\%), 7$ 例 $(54 \%)$ vs20 例 (22\%)，4例 (31\%) vs5 例 (5\%)). 術後無再発生存期間は A 群で有意に長期間であった（574 657 日 vs $360 \pm 275$ 日)。A 群ではリンパ節単独再発が有意に高頻度 で (8 例 $(61 \%)$ vs27 例 $(29 \%))$ 頝部リンパ節再発が多かった. 再発に対する治療内容，効果は両群間に差を認めなかった。 【結語】頚部食道癌例, 軽度進行度例, 長期無再発例, 頚部りン パ節再発例では再発後長期生存が可能になる場合がある. 
PC-1-029 内視鏡下クリッピングが有効であった食道癌 術後の食道胃管吻合部縦隔気管瘦の 1 例

公家健志，溝㴊俊二，前田博教，松本康久，笹栗志朗

（高知医科大学第 2 外科）

食道痹術後約 6 ヶ月に発症した吻合部緥隔気管瘦に対し，内視鏡 下クリッピングを行い瘦孔閉鎖に成功したので報告する. [症例】 63 才, 男性. 平成 12 年 10 月 30 日, 胸部食道癌 $(\mathrm{Mt}, 0-\mathrm{IIb}+\mathrm{IIa}, 5$ $\mathrm{cm}$ 大: $\mathrm{T}_{1} \mathrm{a}, \mathrm{N}_{0}, \mathrm{M}_{0}, \mathrm{pStage}$ 0) に対して非開胸食道抜去, 胸骨後 頝部食道胃管吻合術を施行. 縫合不全なく退院するも吻合部狭窄出 現, 平成 13 年 1 月, タングステンブジーによる自己ブジーを導入. 平成 13 年 3 月頃より咳濑が出現, 增悪. 5 月 22 日の上部消化管造 影にて食道胃吻合部緥隔気管廔を認め入院. [入院後経過]内視鏡下 バルーン搪張術, フィブリン糊充填術を試みるも無効であり，内視 鏡下クリッピングによる瘦孔閴鎖を試みた。当初, 瘦孔を正面視で きず失敗に終わったが，透明キャップ装着により正面視，クリッピ ング可能であった. 1 週間後の上部消化管造影にて瘦孔への造影剂 の流出はみられず，経口摄取を再開．胸部 CT・内視鏡・気管支鏡 でも改善が得られ退院となった. [まとめ]検索した限りでは食道癌 術後の食道胃吻合部緶隔気管廔に対するクリッピング閉鎖成功例 の報告はみられなかった。内視鏡下クリッピングは低侵襲で安全な 手技であり，積極的に試みてよい方法と考えられた。

PC-1-030 術後胸腹水の管理に難渋した肝硬変合併胸部 食道癌の一例

洪 晶恵, 大杉治司, 竹村雅至, 李 栄柱, 上野正勝, 田 中芳憲, 福原研一朗, 藤原有史, 橋本幸恵, 木下博明 (大阪市立大学大学院医学研究科消化器外科)

【症例】55 歳男性, 肝機能異常があったが耐術可能と判断し, $\mathrm{UtMt}, \mathrm{T}_{2} \mathrm{~N}_{0} \mathrm{M}_{0}$ stageII の食道癌に対して開腹開胸下に 3 領域 リンパ節郭清食道切除・後縦隔严全胃再建を行った。術翌日 多量の腹水流出を認めたため腹腔ドレーンを抜去した。経口 摄取開始後, 術 9 日目に右胸腔ドレーンの排液が 2000 4000 $\mathrm{ml} /$ 日と增加した. RI リンフォグラフィにて胸管損傷はな かった. 術27日目より腹水の静脈内濃縮還元を開始した. 術 29 日目に胸腔ドレーンをクランブ, 腹水が貯留したところで 腹腔ドレーンを再挿入し, 胸水隇少を確認して胸腔ドレーン を抜去した. 腹腔ドレーンは㨂入 3 週後よりクランプし胸水 眝留がないことを確認して, 術 12 週目に退院となった. [考 案・結語】当施設では術後の䓵下機能に優れた後縦隔再建を 第一選択としている. 本例では, 術早期に腹腔ドレーンを抜 去したため食道裂孔部を通じて陰圧の胸腔内一腹水が流入 したと考える. 従って肝硬変合併例では腹水增加に備えて胸 腔ドレーン抜去後まで腹腔ドレーンを留置すべきである. な お，乳糜胸水の鑑別に RI リンフォグラフィが有用であった。
PC-1-031 胃全摘術における再建術式の評価一Roux-enY 法, Double Tract 法及び空腸間置術の比較—

村上 望, 北川 晋, 八木真悟, 足立 厳, 森田克哉, 原 田 猛，加藤秀明，飯野賢治，山田哲司

（石川県立中央病院一般消化器外科）

【目的】胃全摘術に扩ける再建術式の評価を Roux-en-Y 法 (RY), Double Tract 法（DT）および空腸間置術（JIP）の3法について急 性期と慢性期に分けて検討を行った. [対象】胃全摘術を施行し,無再 発で stage $2 \cdot \mathrm{D} 2$ ・根治度 $\mathrm{A}$ または B の症例を対象とした. RY 群 31 例, DT 群 19 例, JIP 群 8 例であった. 【方法】急性期の指標とし て,手術時間・術中出血量および入院日数を検討した.また慢性期の 指標として, 体重増加率・PNI ·血中 $\mathrm{Hb} \cdot \mathrm{Fe} \cdot \mathrm{TP} \cdot \operatorname{Albumin}(\mathrm{Alb})$ ・T. cholesterol $(\mathrm{TC}) \cdot \mathrm{Ca} \cdot \mathrm{P}$ および葉酸・Vit. B12を用いた。 【結果】術後の栄養指標として, TP, TC, Alb および PNI では, TC の 3,36 および Alb の 3, 6, 12,36 カ月後において，また TC の 3,6 力月後および Alb の 36,60 力月後において DT 群が RY 群より有 意に良好であった. PNI では, 3, 6, 12 力月後において JIP 群は他の 2 群よりも有意に良好であった．また Ca では 6 カ月後で JIP 群は RY 群より有意に高值をとったＶVit． B 12 および葉酸は DT・RY および JIP 群の 3 群間で比較したが, 有意差は認めなかった. [結語】 JIP 群は各因子および各術後期間において良好な傾向を認めたが， 長期生存例に対する術式を確定することは困難であった。

\section{PC-1-032 上部胃癌切除症例の検討}

小谷幸生, 関屋 亮, 宮崎哲真, 帖佐英一, 中島 健, 児 玉英之，中村都英，松崎泰憲，鬼塚敏男

（宮崎医科大学第二外科）

【目的】上部胃癌切除症例を臨床病理学的に分類比較し切除 範囲，リンパ節郭誠範囲について検討した. 【方法】1979 年 4 月から 2000 年 6 月まで当科で切除した上部胃癌症例 99 例 を対象とした.【結果】男性 68 例, 女性 31 例, 年齢は 28 86 歳, 平均 64.6 歳であった. 根治度 $\mathrm{A}, \mathrm{B}$ 症例 77 例, 根治度 $\mathrm{C}$ 症例 22 例であった. $\mathrm{mp}$ までのリンパ節転移部位は $\mathrm{sm} 2$ が No7, mp が No1, 3, 7 であった. 腫瘍径では $2.5 \mathrm{~cm}$ 未満で はリンパ節転移を認めなかった. $2.5 \mathrm{~cm}$ 以上 $5.0 \mathrm{~cm}$ 未満では 25 例中 10 例 $(40 \%), 5.0 \mathrm{~cm}$ 以上では 56 例中 40 例 $(71.4$ \%)であった. 根治度 A，B症例で術式を検討すると噴門側 切除, 部分切除は 9 例で施行し, 深達度は $\mathrm{m}$ が 5 例, $\mathrm{sm} 1$ が 3 例, se が 1 例, 全例リンパ節転移は認めなかった. 全摘, 幽門側切除は 68 例施行した. 5 年生存率は噴門側切除, 部分 切除は $87.5 \%$ で全摘，幽門側切除は $68.0 \%$ で有意差は認め なかった【総括】 $\mathrm{sm} 2, \mathrm{mp}$ 癌においても噴門側胃切除 +D1 + No 7 の郭清で根治性が得られる可能性が示唆された. ss では $2.5 \mathrm{~cm}$ 未満では噴門側胃切除が可能と思われた。 
PC-1-033 胃癌と他臓器との重複癌症例の検討

武内秀也, 安部良二, 狩峰信也, 南原 繁, 富川盛雅, 金 城 直, 秦 陽子, 上尾裕昭

（大分県立病院外科）

\section{【目的】胃癌と他臓器との重複癌症例の臨床病理学的特徴を検討} した.

【対象および方法】1990 年 1 月より 2001 年 12 月の期間に当科に て手術を施行した原発性胃癌.943 例のうち，他臟器との重複癌 を認めた 55 例 $(5.8 \%)$ を対象とし，胃癌先行 2 例 (A 群)，他臟 器癌先行 27 例 (B 群), 胃癌と多臓器癌の発生間隔が 1 年末満の 同時性 26 例（C 群）の 3 群に分類した。

【結果】1. 癌家族歴を A 群 1 例 (50.0\%), B 群 10 例 (37.0\%), $\mathrm{C}$ 群 8 例 $(30.8 \%)$ に認めた. 2 . 重複癌の発生間隔は C 群では平 均 4.2 カ年であったが，B群では他臓器癌後 10 年を経過後に胃 癌を 6 例 $(22.2 \%)$ 認めており最長は 30 年であった. 3. 胃癌進行 度は早期癌を $\mathrm{A}$ 群 1 例 (50.0\%)，B 群 20 例 (74.1\%), C 群 8 例 (30.7\%) に認め, 根治度 A の症例は A 群 1 例 (50\%)，B 群 22 例 $(81.5 \%) ， C$ 群 21 例 (80.8\%) で高率に根治術が施行された。

【結論】多臟器と重複する胃癌は早期癌が多く，根治度の高い手 術が施行されていた。 また癌家族歴を認める他癌既往例では治 癒と安心させられる後でも胃癌の重複を考慮する必要がある.

PC-1-034 CY1 で根治度 C となった胃癌症例の胃切除 後腹腔内洗浄細胞診の意義

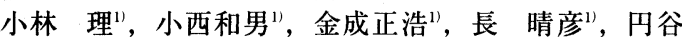
彰 ${ }^{1}$ ，西連寺意勲 ${ }^{1)}$ ，本橋久彦1)，吉川貴己 ${ }^{2)}$

(神奈川県立がんセンター消化器外科 ${ }^{1}$, 横浜市立大学第 一外科 $\left.{ }^{2}\right)$

目的】胃癌の腹腔内洗浄細胞診陽性 (CY1) は StageIV の根治度 C となった. 今回は CY1 のみが根治度 Cの因子となった症例の胃切除 後腹腔内洗浄細胞診の意義を検討した. 【対象と方法】 1988 年から 01 年の期間に CY1 で根治度 C となった症例中, 胃切除後に腹腔内洗浄 細胞診を施行した 15 例. 胃切除後腹腔内洗浄細胞診 (cCY) の方法 は迅速診断で CY1 となった症例に閉腹の直前に腹腔内を $3,000 \mathrm{ml}$ の 生食で洗浄後に行った.【結果】胃切除後細胞診陽性 (cCY1) は 3 例, 陰性 (cCY0) は 12 例であった. 術後生存期間は 84 日〜 4885日 (me-

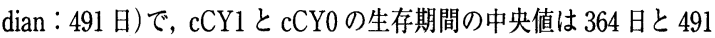
日で有意差はなかった. $\mathrm{cCY} 1$ の 3 例は 2 年以内に腹膜転移で全例死 亡. cCY0 で死亡した 6 例の死因は腹膜転移が 4 例で 2 例には腹膜転 移を認めず，リンパ節転移と遠隔転移 (肺と骨) で死亡. 現在生存中 の 1 例は術後 14 年現在腹膜転移がなく, 1 例は 1 年 3 か月後に\# 16 リンパ節転移，その 7 か月後に骨転移と腹膜転移が出現している. Follow up 期間が 1 年末満の 4 例中 1 例は 11 か月後に腹腔鏡で腹膜 転移を認め, 3 例には腹膜転移をまだ認めていない.【結語】CY1 例に おける胃切除後の腹腔洗浄細胞診は予後因子として有用である。
PC-1-035 CPT-11/CDDP療法にてCRが得られた StageIV 胃小細胞癌の 1 例 五箇猛一，田内克典，有賀浩子，千須和寿直，河西 秀， 大森敏弘, 小池秀夫

(相澤病院消化器外科)

68 歳男性, 心窩部痛を主訴に平成 13 年 5 月 16 日近医 受診.上部消化管内視鏡検査にて胃体上部小彎に 3 型腫 瘍を指摘され，手術目的にて 5 月 22 日当科紹介となる。 同日上部消化管内視鏡検査再検し，体上部小彎から後壁 の 2 型腫瘍を認め，生検で小細胞癌の診断を得た. CT にて多発肝転移，リンパ節転移を認め StageIV 胃小細胞 癌と診断した．肺小細胞癌の化学療法に準じ, CPT-11/ $\mathrm{CDDP}$ 療法を施行. 1 クール終了時点で PR となり NSE は $110 \mathrm{ng} / \mathrm{ml}$ から $4.5 \mathrm{ng} / \mathrm{ml}$ に減少した.3クール終了後に は胃病変は躿痕となり, CT 上肝転移およびリンパ節転移 は消失し CR と判定した．現在 CR 継続中である. 化学療 法にて CR となった胃小細胞癌の報告は認められず, 貴重 な症例と思われた。

PC-1-036 腹部大動脈周囲リンパ節転移の郭清と術後化 学療法により無再発生存中の胃癌の 1 例 小笠原和宏, 高橋 学, 小川秀彰, 井本秀幸, 菊地一公, 柿坂達彦, 山本 貢, 真鍋邦彦, 内野純一 (労働福祉事業団釧路労災病院外科)

【症例】 43 歳・男性. 術前診断は, cType 2, T2 (SS) N $1 \mathrm{H} 0 \mathrm{M} 0$, cStage II. 1997 年 12 月 2 日, 幽門側胃切除術を 行ったが，腹部大動脈周囲に多数の腫大リンパ節を認め, \# 16a1 から＃16b2 まで広範囲に郭清した。病理診断は， por1 >>tub2, pT2 (SS) ly2 v2 pN3 CY0 M1 (LYM), pStage IV fCur B で，リンパ節転移は\# 16a1 : 14/18 \#16 a2 : 11/16\#16b1 : 35/58 \#16b2:2/7 その他：18/61 で あった. 術後の low dose FP は Grade3 の下痢と悪心・湢 吐のため中止，5’-dFUR 1200mg を投与した。 CA19-9 が術前後で $1195 \mathrm{U} / \mathrm{ml}$ から 46 まで低下したが, 術後 5 ヶ 月で 121 まで再上昇したため, Etopside + EPIR + CDDP

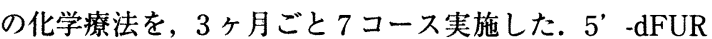
は継続投与とし, 4 年 2 ヶ月の現在, 無再発生存中である. 【考察】各リンパ節転移の周囲への浸潤傾向がそしく, 遺 残なく郭清可能であった. 可及的隇量という意味で郭清 の果たした役割は大であった。 
PC-1-037 術前化学療法が著効を示した胃壁内進展食道 癌に十二指腸進展胃癌を合併した一例

今野元博, 加藤道男, 十川佳史, 酒井健一, 市川英明, 西 川正康, 石丸英三郎, 保田知生, 大柳治正

(近畿大学医学部第二外科)

術前化学療法が著効した胃癌の十二指腸進展と食道癌の胃壁 内進展による広範な病変をみた一例を経験したので報告する.症 例：73 歳, 男性. 心裔部痛・食欲不振を主訴に来院. 検查所見： 中下部食道から腹部食道にわたる全周性の高度な狭窄と, 小弯側 胃壁の大部分と大弯側体中部から幽門輪ににかけて, 十二指腸下 行脚に及ぶ硬化像が認められた. 前庭部後壁にひだの集中と白苔 を伴う不正な潰場が存在した. 画像診断の結果, 食道・十二指腸 に浸潤したびまん浸潤型の高度進行胃癌と診断した.この症例に 対し down staging を目的とした術前化学療法 (CDDP 70mg $/ \mathrm{m}^{2}$ $\times$ day $1,5-\mathrm{FU} 700 \mathrm{mg} / \mathrm{m}^{2} \times$ day $1 \sim 5 / 21$ days $\left.\times 3\right)$ を施行. 化学療法 後の緒検査で PR を得たため切除可能と判断し胃全摘を施行し た.切除標本の検索では幽門輪付近の筋層内に viable な中分化を 示す腺癌組織が残存していた. また食道胃接合部には扁平上皮癌 が存在したため下部食道癌と診断した. また上中部胃壁内のリン パ管内および転移リンパ節内の癌細胞も扁平上皮癌であった. 胃 癌・食道癌とも組織型が異なっていた両者に術前化学療法が著 効を示した症例として興味深いので報告した。

PC-1-038 術前低用量 CDDP/5Fu 療法が著効した腹部 大動脈リンパ節転移陽性胃癌症例の 1 例

野本一博, 齊藤光和, 高橋博之, 齊藤文良, 井原祐治, 塚 田一博

（富山医科薬科大学第 2 外科）

【目的】胃癌に対する neoadjuvant chemotherapy（NAC）は確 立されていないのが現状である.今回, 術前低用量 $\mathrm{CDDP} / 5 \mathrm{Fu}$ 療法 (low dose FP) を施行し, 著効した胃癌症例を経験したの で報告する. [症例]症例は 66 歳の男性. 術前検查で, 胃体部中 心に巨大な 3 型の腫場を認め (生検は por1), 16a2 リンパ節を含 む広沉なリンパ節転移が疑われた. MUL 領域の 3 型の胃癌で, cT3cN3cP0cH0cM0, cStageIV と診断し, 術前に $5 \mathrm{Fu} 500 \mathrm{mg} /$ day $\cdot$ day 1 5 の 5 日間持続投与と, CDDP $10 \mathrm{mg} /$ day, 1 時間 点滴 day $1 \sim 5$ を 4 週間投与する low dose FPを施行した. low dose FP 施行後, 原発巣は PR, リンパ節転移も PR と判定した. sT2sN2sP0sH0sM0, sStageIIIa の診断で, 萭脾合併胃全摘術, D $2+16$ リンパ節郭清術を施行. 切除標本の原発巣およびリンパ 節に癌胞巣は見出されず, 組織学的効果は Grade3 と判定した。 術後 3 年経過した現在, 再発の兆候を認めず, 外来通院中であ る.【結語】術前 low dose FP が著効した胃癌症例を経験した。 NACを施行するにあたり, 適切な治療法の選択とその療法に奏 効する適切な患者選択が重要であると考えられた。
PC-1-039 切除不能再発胃原発 malignant GIST に対し メシル酸イマチニブ（グリベック）が著効した 1 例 小熊英俊, 笹川 剛, 喜多村陽一, 梁取絵美子, 武市 綾, 高崎 健

(東京女子医科大学消化器病センター外科)

(はじめに) 我々は切除不能の再発胃原発 malignant GIST に 対しグリベックが著効を示した症例を経験したので報告す る. (症例) 初発時 37 才, 男性. 検診における上部消化管造影 検查にて異常を指摘され来院した．胃体上部原発の粘膜下腫 瘍と診断し, 1999 年 1 月, 噴門側胃切除術, 食道残胃間結腸 間置術を施行．組織検査では $\alpha \mathrm{SMA}(-), \mathrm{S} 100$ 蛋白 $(-)$, CD34 (+)，c-kit (+) であり, mitosisを認めたことから胃 原発 mlignant GIST と診断した. 術後経過観察中の 2000 年 4 月より 2001 年 6 月までの間に腹膜転移再発, 肝転移再発を認 め, 計 5 回の腫瘍摘出術を行った. 2001 年 10 月, CTにて残 肝腫瘤, 腹腔内腫瘤および腹部大動脈周囲の腫瘤を認め, 再発 と診断するも腫瘤摘出不可能と判断した．そこで， 10 月 29 日よりグリベック $300 \mathrm{mg} / \mathrm{day}$ の服用を開始. 6 週後のCT 検查にて肝腫瘤および腹腔内腫瘤は壊死化, 大動脈周囲腫瘤 は消失した. 14 週後のCT 検査にて肝および腹腔内壊死化病 変は縮小した. (考察)グリベックは今後, c-kit 陽性の再発 malignant GIST に対する第一選択治療薬となる可能性がある.

PC-1-040 胃 GIST 術後再発に対する Gleevec の効果

矢野隆嗣, 玉置久雄, 三田孝行, 大橋直樹, 松本英一, 熊 本幸司

(松阪中央総合病院外科)

[症例 $] 2000$ 年 8 月より時々 nausea あり。近医を受診し， u-GIS, 胃内視鏡で胃体部小弯の SMT と診断され当科へ紹 介. US, CT で, 胃体部小弯側に dumbbell 型の SMT が認 められた $(6 \times 5 \mathrm{~cm}$, 壁外発育主体)。2000 年 12 月筋原性腫 瘍の診断で, 胃局所切除を施行. 摘出標本は, 体部小弯原 発の弾性軟の腫瘤 $(60 \times 40 \times 50 \mathrm{~mm})$ 組織学的には，核異 型を伴う紡錘型細胞が増殖, 細胞密度が高く, 分裂像も $1-4$ 個/1 視野と多く, GIST with low grade malignancy と診断された. 2001 年 8 月 (術後 8 ケ月)にCTで 2 箇所 の局所再発が確認された(胃小弯側, 肝門部)。再手術を行 い, 先ず肝門部の再発腫瘤摘出を試みたが, 脆弱で rupture し, 吸引除去. 胃小弯側腫瘤は cystic degeneration を来た し, ruptureによる播種促進が危惧され, 切除を断念. 以後 外来 follow となる. 2002 年 10 月 26 日, Imatinib (STI571) $300 \mathrm{mg} / \mathrm{day}$ を開始した. 腹部 CT で小弯側再発巣のサイ ズを follow しているが, 投与開始後 4 ケ月で, 著しい縮小 が観察された（最大径 $8 \rightarrow 5.3 \rightarrow 4.5 \mathrm{~cm} / 4$ months）. 
PC-1-041 tegafur/CDDP/IV (Chronomodulation chemotherapy）+CPT-11 が奏効した非切除・再発胃癌の 3 例 小林 中, 廣瀬哲也, 山田卓司

\section{（廣瀬病院外科）}

【目的】非切除胃癌 2 例 - 術後再発胃癌 1 例に対して, 副作用軽減 と抗腫場効果增強を目的とした薬物動態の日周リズム (circadian rhythm）を応用する Chronomodulation chemotherapy (CC) を tegafur/cisplatin (CDDP)/isovorin (IV) の 3 剂を用いて施行後, CPT-11を付加する併用化学療法を行い, 有効性を検討した. 【方 法】 tegafur $800 \mathrm{mg} /$ body $16 \mathrm{~h}-0 \mathrm{~h} \mathrm{civ}+400 \mathrm{mg} /$ body $/ 0-8 \mathrm{~h}$ civ, day 1-12 + CDDP 10mg/body + IV25mg/body/16h oneshot iv, dayl5, day8-12 + CPT-11 100mg/body/16h oneshot iv, day 13 を 1 コースとして, 1 or 2 コース施行. CPT-11は 2 コース目は 150 $\mathrm{mg} /$ body まで増量. 【結果】非切除胃癌 2 例に対し PR, 術後再発 胃癌 1 例に対して MR を得た. 副作用は grade2 以下の消化器症 状，骨髄抑制，脱毛のみであった【[結語】非切除・術後再発胃癌 に対して, 腫瘍增殖が盛んで, 正常細胞に感受性が低い夕方から 夜間に抗腫瘍薬を投与することで有効性を高め, 薬物有害反応を 軽隇する CC に, 作用機序が異なり, FP 療法と組み合わせること で，より高い奏効率を示す CPT-11 を付加することで，短期間で 行える副作用の少ない化学療法の一つになりうると思われた。

PC-1-042 進行胃癌に対する TS-1/CDDP 併用術前化学 療法

泉 信行, 原田知明, 恒松一郎，岩本伸二，原 章倫，佐 竹一成，宮崎治男

(大阪府済生会吹田病院消化器 - 一般外科)

【目的】中等度・高度進行胃癌に対して, 術前に TS-1/ CDDP 併用療法を行い, その効果を検討した. 【対象と方法】 進行胃癌 13 例を対象とした. TS-1 の投与量は $80 \sim 120 \mathrm{mg} /$ day/body を原則的に 3 週投与 1 週休薬, TS- 1 内服開始 8 日目に CDDP $60 \sim 100 \mathrm{mg}$ 静脈内投与を 1 クールとして, 1 〜4クール施行した.うち 3 例は CDDP $10 \mathrm{mg} / \mathrm{day} \cdot 5$ 日間 の少量投与, 別の 1 例は 1 回目 $70 \mathrm{mg} 2$ 回目 $90 \mathrm{mg}$ の CDDP 動脈内投与とした.【結果】bPR4 例. 奏効率 $30.8 \%$. bPR4 例のうち 1 例は, 残存潰瘍を認めたが術後標本切片上㾔遺 残はなかった。他の 3 例は, 縮小した crater 部に癌遺残を認 めるだけで, 周囲の周堤は平坦化し癌細胞を認めなかった. しかし， 4 型胃癌 5 例中 4 例は効果がほとんどなかった。薬 物有害反応は, 白血球隇少 Grade $1: 2$ 例 Grade $2: 4$ 例. 血 小板減少 Grade1 $: 1$ 例. 食欲不振 Grade $2: 1$ 例, 発疹 1 例. 【結語】 TS1-CDDP 併用療法は腫瘍縮小効果の面からは切れ 味が良いとは言えない.ほとんど効果を認めていない症例 があるので，今後再検討が必要と思われる.
PC-1-043 高度進行胃癌に対する TS-1/Low dose CDDP 術前化学療法の検討

才川義朗"，金井歳雄"，赤坂喜清2，坂田道生 ${ }^{12}$ ，川野幸 夫"，中川基人”，高林 司”

(平塚市民病院外科"), 東邦大学医学部第 2 病理学教 室 $\left.{ }^{21}\right)$

われわれは 2001 年 6 月より, cStage IV 進行胃㿋例に 対して術前 TS-1/Low dose CDDP 療法（TSLD）を開始 し，その効果・毒性・手術への影響について検討を加え た。根治手術困難症例（cSI または $\mathrm{cP} 1$ または $\mathrm{cN} 2$ 以上） 7 症例, 手術適応外症例; $\mathrm{cP} 1$ 高度 2 例, $\mathrm{cH} 13$ 例で, 合 計 12 例に対して TSLD が行われ，原発巣切除は 7 例に行 われ，組織学的効果判定は grade la 3/7, grade $1 b-24 / 7$ で全例に効果を認めた. 出血・摄食不良による $\mathrm{QOL}$ 低下 例 3 例中 3 例に化療後 QOL が改善した. 副作用は白血球 隇少が 7 例中 3 例に認められ，無治療で改善した。食欲不 振・嘔気は 2 例に出現し, 途中で治療を中止した. 7 例と もに原発巣切除後, 特に術後合併症もなく退院し, 術前 TSLDによる手術への負の影響はなかったと考えられ た. 高度進行胃癌に対する術前 TSLD の長期予後への影 響は未だ不明であるが, 高率に奏効する本療法は再発・ 転移を子防しうる有用な方法と期待される。

PC-1-044 切除不能幽門狭窄合併胃癌に対する胃空腸吻 合術 TS-1 併用療法の有用性

橋本幸恵, 大杉治司, 竹村雅至, 李 栄柱, 上野正勝, 田 中芳憲, 福原研一朗, 藤原有史, 西澤 聡, 木下博明 (大阪市立大学医学部消化器外科)

【はじめに】幽門部切除不能胃癌では幽門狭窄のため, 入 院での経静脈栄盖および経静脈的化学療法を選択せざる を得ず，患者の QOL を損なうことが多い．このような症 例に対し, 胃空腸吻合によるバイパス術を行い, 経口路を 確保してから TS-1 投与を行うことで在宅加療を可能と した. 【症例】5 例の切除不能胃癌症例に対し, 4 例に Roux$\mathrm{Y}$ 型， 1 例に Billroth II 型胃空腸吻合術を施行した．胃癌 占居部位は $\mathrm{LD}$ が 4 例, LMD が 1 例であり, 周囲臟器へ の直接浸潤と腹膜播種を認めた。胃は切離せず, 胃病変か ら $10 \mathrm{~cm}$ 以上離れた口側大弯に胃空腸側々吻合した。術後 経口摄取可能となると同時に TS-1 内服を開始した。術後 平均在院日数は 29 日, 平均在宅加療期間は 193 日であっ た. 3 例は術 $3,4,22$ ヶ月後に死亡したが, 2 例は術 4,10 ケ月後の現在も在宅生存中である.【結語】切除不能胃癌 に対し TS-1 投与目的で積極的に胃空腸吻合術を行い経 口㠌取可能とすることで, 在宅加療可能となり, QOL は向 上すると考えた。 
PC-1-045 4 型胃癌に対して, 非切除・TS-1 投与を行っ た 7 例

伊藤誠二"1，望月能成"，金光幸秀"，清水泰博"，平井 孝 ${ }^{11}$, 安井健三 "), 山村義孝 ${ }^{1}$, 加藤知行 ${ }^{11}$, 小寺泰弘 ${ }^{21}$ (愛知県がんセンター病院消化器外科 ${ }^{1}$, 名古屋大学第 2 外科2)

【目的】腹膜播種を伴う 4 型胃癌に対しては, 現在でもなお標準 的な治療は存在しない，今回，腹膜播種を伴う 4 型胃癌に対し て, 非切除・TS-1 投与を行った症例について検討し，その標準 治療について考察した【【方法】 4 型胃癌に対して非切除・TS1 投与を行った 7 例につき，その生存期間などを検討，1989 年から 1998 年までに胃切除を行った症例と比較した. [成績]7 例中， 6 例は試験開腹あるいは腹腔鏡検査で腹膜播種を認めた ため, 1 例は腹腔鏡検査で洗浄細胞診陽性のため，それぞれ非 切除となった．このうち，2 例は TS-1 投与を継続しつつ生存 中, 2 例は PD のため, 他の化学療法を行いつつ生存中, 3 例は 原病死している. 7 例の平均生存期間は 447.9 日, 平均外来通院 期間は 398.9 日であった。一方,切除を行った 157 例のうち術中 所見で腹膜播種陽性の症例の平均生存期間は 387.9 日であっ た. 【結論】腹膜播種を伴う 4 型胃癌に対し, 非切除・TS-1 投与 により, 従来の胃切除と遜色のない生存期間が得られた. 今後, 腹膜播種を伴う 4 型胃癌の標準治療を検討する際には, 非切除 +TS-1 投与も，比較対象として考慮すべきと考えられた。

\section{PC-1-046 リンパ節転移陽性早期胃癌手術症例の検討}

帖佐英一，関屋 亮，宮崎哲真，小谷幸生，中島 健，児 玉英之，中村都英，松崎泰憲，鬼塚钽男

（宮崎医科大学第 2 外科）

【目的】リンパ節転移陽性早期胃癌手術症例について検討した。 【方法】1978 年 3 月から 2001 年 1 月までに当科で施行した D $1+$ No7 以上のリンパ節郭清を行った早期胃癌手術症例 251 例 のうち，リンパ節転移陽性であった 27 例を転移陰性例 224 例 と比較検討した.【結果】両群間に有意差が認められたのは, 性 別，腫場最大径，深達度および脈管侵襲であり，年齢，占居部 位, 肉眼型, 組織型および術式には有意差は認められなかった。 リンパ節転移は, $\mathrm{m}$ 癌では深達度 $\mathrm{mm}$ 症例の 1 例 $(1 / 133,0.8$ \%)のみで, $\mathrm{sm} 1$ 癌では 3 例 $(3 / 27,11.1 \%), \mathrm{sm} 2$ 癌では 23 例 (23/91,25.3\%) であった５生率，10生率はn一群がともに $99.5 \%$ であり, $\mathrm{n}+$ 群は $83.1 \%, 76.2 \%$ であった. 再発死亡症例 6 例のうち 5 例が $\mathrm{n}+$ であり, 再発形式は, 5 例が血行性転移, 1 例がリンパ節転移であった.【総括】m 癌, $\mathrm{sm} 1$ 癌の 5 生率 10 生率は $100 \%$ であり，良好な予後が得られた。リンパ節転移率 は $\mathrm{sm} 1$ 癌症例は $11.1 \%, \mathrm{sm} 2$ 癌症例は $25.3 \%$ であったが, 転移 症例の予後は 5 生率 $83.1 \%, 10$ 生率 $76.2 \%$ であった。 早期胃癌 再発死亡例 6 症例は, すべて $\mathrm{sm} 2$ 癌症例であった。
PC-1-047 胃癌卵巣転移切除例の実態と予後について

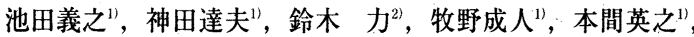
松木 淳", 大橋 学", 中川 悟”, 西卷 正", 畠山勝義” (新潟大学大学院一般・消化器外科学分野), 新潟大学医 学部保健学科 ${ }^{21}$ )

[背景・目的］胃癌の卵巣転移（Krukenberg腫場）切除例の実態 と予後を明らかにする. [対象] 1961 1995 年の胃癌卵巣転移切除 例 21 例 (平均 47.2 歳; 25 73 歳). [方法] 診療録, 病理報告上り 臨床病理学的背景と予後に与える影響につき retrospectiveに解 析した. [結果] 全例で胃切除が施行され，卵单切除は同時性 14 例, 異時性 7 例. 切除側は両側 8 例, 片側 10 例 (右 6 例, 左 4 例), 不明 3 例. 同時性切除の多くは術中に卵巣転移と診断された. 異時 性切除 7 例中 4 例は開腹時に腹膜転移が明らかとなり，うち R0 切除は 2 例に過ぎなかった。全 21 例中 R 0 切除は 7 例 (33\%)， R 2 切除はいずれも腹膜播種陽性例であった. $50 \%$ 生存期間 (MST) は 10 か月, 1 年生存率は $28.6 \%, 2$ 年生存率は $4.8 \%$, 最長生存期 間は 2 年 3 か月であった。同時性及び異時性切除例の MST はそ れぞれ7 か月，10か月であった．R0切除例の MST は 7 か月，1 年生存率は $28.6 \%$ で， R2 切除例ではそれぞれ 10 か月，23.1\% で あり，化学療法施行例及び非施行例の MST はともに 6 か月で あった. [結果]胃癌の卵巣転移は腹膜播種を伴うことが多く,肉眼 的根治切除を行い得ても生存期間延長への寄与はない.

PC-1-048 残胃癌と上部胃癌における臨床病理学的検討

村上仁志"1, 大島 貴 ${ }^{3)}$, 塩澤 学"1, 蓮尾公篤"), 利野 靖"), 高梨吉則", 西連寺意勲"), 本橋久彦"), 今田敏夫 ${ }^{3 \prime}$ (横浜市立大学医学部第一外科", 神奈川県立がんセン 夕ー ${ }^{21}$, 横浜市立大学医学部付属市民総合医療センター 消化器病センター ${ }^{3 \prime}$ )

【目的】残胃の癌は原発癌に比べ予後が悪いとされている. 残胃 癌と胃上部の初発癌について臨床病理学的因子及び治療効果 について検討した.【方法】対象は残胃癌 59 例と胃上部の初発 癌 579 例. これら 2 郡間おける組織深達度, リンパ節転移, 病 理組織型，病期分類等の諸因子拈よび生存率について解析を 行った.【結果】 2 群間においてリンパ節転移率について有意な 差はなかった. ただし残胃の癌ではその転移リンパ節部位に変 化が認められた。残胃癌では治癒的切除が不可能であった例が 有意に多く, 初回手術による周囲への癒着により近接臟器への 浸潤が比較的容易に起こる為と考えられた。進行残胃癌におけ る治癒切除後の 5 生率は $50.9 \%$ であり, 早期あるいは治癒切除 が行われた残胃癌では原発癌と生存率について有意な差は認 めなかった. 漿膜浸潤のない残胃癌症例では良好な予後が得ら れた.【結論】治癒切除が行われれば残胃の癌においても胃上部 の初発癌と予後に関して差は認めなかった. しかし槳膜浸潤を 起こした症例の予後は悪く, 残胃癌においての早期診断は予後 の改善に特に重要であると考えられた。 
PC-1-049 胃重複症に合併した胃癌が，重複胃に浸潤し た 1 例

菊地洋一, 水沼 廣

（須賀川病院外科）

(目的) 胃重複症は消化管の先天的形成異常の 1 つで, 80 数例 の本邦報告例がある.今回我々は胃癌が重複胃に浸潤した極 めてまれな症例を経験したので報告する. (症例) 66 歳女性. 主訴は全身倦怠感. 平成 13 年 8 月 13 日胃癌と診断され, 当院 紹介された. 筫血があり, 右上腹部に $10 \mathrm{~cm}$ 大, 弾性硬, 表面 平滑な腫瘤をふれた，上部消化管造影では 2 型の腫瘍病変が あり，胃内視鏡下の生検にて Group5 と診断された. CT では 右上腹部に $11 \mathrm{~cm} \times 6 \mathrm{~cm}$ 大の隔壁を持つ敏胞性病変があり， 胃, 十二指腸と接していた。胃癌に合併した胃十二指腸の亚胞 と診断し 9 月 26 日手術を行った. 胃下部大彎に槳膜に覆われ た，境界明瞭で内腔に暗赤色内容物を含む豊胞性病変を認め た．胃癌は裹胞の粘膜面にあり．幽門側胃切除術，D2 リンパ 節郭清, Billroth2 法再建を行った. 囊胞壁には胃の固有筋層に 連続した平滑筋が存在し，内面の一部に胃の粘膜上皮がみら れる部分があり，重複胃と診断された。胃癌は高分化型腺癌で INF $\beta$, ly0, v0 であった. 癌は筋層を貫き浸潤し, 霊胞内に露 出していた. $\mathrm{t} 2 \mathrm{n} 0 \mathrm{P} 0 \mathrm{H} 0 \mathrm{M} 0 \mathrm{cy}$ (-) stagelbであった.

PC-1-050 初発症状が幽門狭窄症であったクローン病の 1 手術例 清水義博, 山口明浩, 内山 清, 塚本賢治

\section{(第二岡本総合病院外科)}

今回我々は，非常にまれな初発症状が幽門狭窄症であったク ローン病を経験したので報告する.症例は 23 嵗男性. 既往歴に特 記事項はない. 平成 13 年 5 月, 食後の嘔吐が出現したため, 当院 受診、上部消化管内視鏡検查で, 十二指腸潰瘍による幽門狭蜜症 の診断で，入院. 生検でHP (-) であった。絶食 IVH，抗潰瘍 郕の治療で軽快せず，広範囲胃切除，B-II 再建術施行。病理検査 で下掘れ潰瘍，裂孔，類上皮肉芽腫が認められ，クローン病と診 断された。入院中に大腸内視鏡検査を施行し，回腸末端部に炎症 性のポリープを多数認め, mesalazine の内服治療を開始し退院し た.クローン病は全消化管を侵す非特異性慢性炎症性腸疾患であ り胃十二指腸病変は稀である。本邦では幽門狭窄を合併した報告 は 21 例にすぎず，初発が本症状であったのは内 6 例の報告があ るのみである.このように稀な症例に対し十二指腸潰場として診 断し手術を施行した.クローン病の幽門狭窄症は手術療法になる ことがほとんどであるが，狭窄形成術や胃腸吻合術，また内科的 なバルーンによる搪張術で改善した報告例もあり，幽門狭窄症は クローン病も必ず念頭に置かなければならない。
PC-1-051 早期胃噴門部癌に対する小開腹下 EMR の試 み

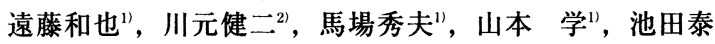
治"，藤也寸志")，鴻江俊治"，岡村 健"

(国立病院九州がんセンター消化器外科"，国立病院九州 がんセンター放射線科(2)

【目的】 EMR（内視鏡下粘膜切除術）は一部の早期胃癌に 対しては標準的治療として定着しているが，噴門部の病 変に対しては困難である. 今回我々は早期胃噴門部癌に 対して，小開腹下に EMR を行い切除し得たので報告す る.【方法】噴門部直下に $2 \mathrm{~cm}$ 程の IIc 病変認め高分化腺 癌と診断された症例に対し，全麻下に左上腹部に $2 \mathrm{~cm}$ 強 の切開を加え開腹, 小開腹創より胃壁を引き出し, 胃体中 部大湾前壁より腹腔鏡用の $15 \mathrm{~mm}$ port を挿入，内視鏡を 挿入し EMR 施行, 病変部を切除した.【結果】患者は術後 特に問題なく 3 日目より経口を開始し，7 日目に退院し た. 病理診断にても癌は分化型, $\mathrm{m}, \mathrm{ly} 0, \mathrm{v} 0, \mathrm{ew}(-)$, そ の後も再発等の所見認められていない.【まとめ】早期胃 噴門部癌に対して開腹下 EMR は他の低侵襲手術と比べ ても簡便であり，侵襲も少なく有効な治療法と考えられ た.

PC-1-052 胃粘膜下腫瘍切除に対する腹腔鏡下手術の検 討 佐藤正範, 川辺昭浩, 島村隆浩, 礒垣 淳, 和田英俊, 小 林利彦, 数井輝久

(浜松医科大学第一外科)

【対象】当科で胃粘膜下腫瘍と診断し腹腔鏡下切除した 8 例 を対象とした，腫瘍の部位と発育形態による術式の選択 ・ 工夫, 術後経過について検討した. 【結果】腫場占拠部位は胃 上 $1 / 3$ に 5 例, 中 $1 / 3$ に 2 例, 下 $1 / 3$ に 1 例, 前壁に 3 例, 大弯に 3 例，後壁に 2 例であった. 生育型分類は管内型 6 例, 管外型 1 例, ダンベル型 1 例であった. 胃体部以下の腫 瘍 6 例に対しては腹腔鏡下楔状切除を施行し, 食道・胃接 合部近傍の 1 例に対しては胃内手術で自動綘合器を用いた 胃部分切除を施行した. また, 後壁の 1 例に対して, 胃切開 下で胃部分切除を施行した．腫瘍の牽引にエンドループや T-barを用いること，体位変換による視野確保が有用で あった. 8 例中 7 例で術後 2 病日より食事を開始した. 術後 平均在院日数は 8 日で, 合併症は認めなかった.【まとめ】胃 粘膜下腫瘍に対する腹腔鏡下手術は, 腫瘍の部位や発育形 態に応じて, 体位やアプローチ, 旁引の方法を工夫して術式 を選択すれば，胃底部の腫瘍や後壁の腫瘍に対しても安全 に施行でき，低侵襲で有用な術式であると考えられた。 
PC-1-053 腹腔鏡下大網充填術後に根治術を行った早期 胃癌穿孔の一例

尾方信也, 西岡将規, 田上誉史, 佐藤宏彦, 宮内隆行, 石 川正志, 柏木 豊, 三木久嗣

(国立高知病院)

症例は 49 歳男性. 平成 13 年 8 月 7 日朝から上腹部痛あり, 痛みが腹部全体に広がり激烈になり当院救急外来を受診し た. 来院時腹部は板状硬で, 胸部 X 線写真では横隔膜下に大 量の遊離ガス像を認めた。 上部消化管穿孔による急性沉発性 腹膜炎と診断し緊急手術を行った. 腹腔鏡で腹腔内を観察す ると胃体下部前壁にピンホール状の穿孔を認めた. 胃潰瘍穿 孔と診断し腹腔鏡下大網充填術を行った. 術後 16 日目に上部 消化管内視鏡検查を行ったところ，胃体下部前壁に A2stage の潰瘍を認め周辺より生検で GroupV, adenocarucinomaを 認めた. 9 月 3 日幽門側胃切除術 D2 を行った. 病理組織検査 では低分化型腺癌, 深達度 sm であった. H0, P0, CY0, M0, T 1, N0, StageIA と診断した。早期胃癌の穿孔は本邦での報告 例は自験例も含め 51 例であった. 穿孔性胃十二指腸潰瘍に対 する治療において minimally invasive surgery や保存的治療 行われる事が多くなっている．しかし本例のように早期胃癌 の穿孔例があるので, 腹膜炎の治療後に十分な検索を行い二 期的な治療を積極的に行うべきであると考えられた.

PC-1-054 胃癌手術における正中切開法と季肋下切開法 の比較

稲葉 毅, 福島亮治, 冲永功太

(帝京大学外科)

【目的】胃癌手術を対象に正中切開法と季肋下切開法を比較した. 【方法】対象は幽門側胃切除術 219 症例, 胃全摘術 100 症例. 術前 に正中切開法 (正中群)，季肋下切開法 (季肋下群) を無作為に選 択し, 開腹, 閉腹, 総手術時間, 術後鎮痛剂使用回数, 肺炎発生, 腸閉塞発生などを prospectiveに比較した.【結果】幽門側胃切除： 開腹, 閉腹, 総手術時間はいずれも季肋下群で有意に長かった. 出 血量, 創感染頻度, 入院期間に差はなかった. 肺炎発生は正中群 6.2 $\%$, 季肋下群 $1.9 \%$ で, 季肋下群でやや低值だった. 持続硬膜外麻 酔併用例に限ると鎮痛剂使用回数は, 正中群 $3.2 \pm 0.3$ 回 $/ 3$ 日, 季助 下群 $2.5 \pm 0.3$ 回 $/ 3$ 日で季肋下群の方が少ない傾向にあった. 第 I 期, 第 II 期の症例に限ると腸閉塞発生は正中群 $6.8 \%$, 季肋下群 0 \%で, 季肋下群の方が少ない傾向にあった. 胃全摘術：開腹, 閉腹 時間はいずれも季助下群の方が長かったが総手術時間に差はな かった. 出血量, 肺炎発生, 創感染発生, 入院期間, 鎮痛剂使用回 数, 癒着性腸閉塞発生頻度には両群間で差は認められなかった。 【結語】幽門側胃切除術では季肋下切開法は正中切開法より, 術後 疼痛管理や腸閉塞防止の点で優れていると示唆された.
PC-1-05585 歳以上の胃癌胃全摘手術症例の検討

小川明男, 神谷里明, 鬼頭 靖, 松永宏之, 成田裕司, 城 田千代栄, 松崎安孝

（津島市民病院外科）

（目的）開腹手術で術後の食思不振をきたす典型的手術であ る胃全摘を超高齢者に施行した症例を検討する. (方法) 1998 年 1 月〜 2001 年 12 月での胃癌胃全摘術 57 例中の 85 歳以 上 5 例を対象とし, 同期間の 70 歳未満の 26 例 (壮年群), 及 び 85 歳以上の胃癌胃切除 8 例 (胃切群) と比較検討. (結果) 男 2 例, 女 3 例. 平均 87 歳. Stage IA3 例, IIIB1 例, IV1 例 (胃切群で Stage IA3 例, IB2 例, IIIA2 例, IV1 例). 胃 全摘（D1）2 例，胃全摘及び荤尾部脾合切（D2）3例（胃切 群で D1 は 1 例, D2 は 7 例). 全例 Roux-en-Y 再建 (壮年群 で Roux-en-Y24 例, 空腸間置 2 例)。縫合不全なし, 術後肺 炎なし. 術後入院期間は平均 40 日 (壮年群で 28 日, 胃切群 で 27 日). 在院死 2 例 (壮年群で 1 例, 胃切群でなし). 再入 院後死亡 1 例. 三群ともに胃術後食を通常の術後食の半量と した. 死亡例で死亡直前食思不振以外に明らかな術後合併症 なし. (結論) 術後短期の死亡率は高く, 今後手術の適応を慎 重にする必要.さらに術後の食思不振に対する十分な栄養管 理に加え付加手術 (再建法の改良, 腸瘦造設等) が必要.

PC-1-056 多彩な病理組織像を示した 0-IIb + III 型早期 胃癌の一例

辻 俊明, 岩橋 誠, 中森幹人, 中村公紀, 勝田将裕, 尾 島敏康, 山上裕機

(和歌山県立医科大学第 2 外科)

【はじめに】 gastritis cystica profunda (GCP) を伴い広範囲に 多彩な病理組織像を示した $0-\mathrm{IIb}+\mathrm{III}$ 型早期胃癌症例を経験 した.【症例】 61 歳男性. 近医にて胃潰瘍フォロー中に内視鏡 で胃角小弯の陥凹病変からの生検で GroupV を認めたため紹 介となった. 内視鏡で胃体下部後壁と前壁にそれぞれ IIc + III 型病変と IIc 型病変を認め, 生検でそれぞれ高分化〜中分化 型腺癌と高分化型腺癌を認めた. EUS で胃体下部小弯に GCP を疑う低エコー領域を認めた。幽門側胃切除, D1+ $\beta$ リンパ節 郭清, BillrothI 法再建を施行した. 摘出標本の組織学的所見で は広範囲の粘膜内に高分化〜中分化型腺癌と一部粘膜下に低 分化〜中分化型腺癌, 粘液癌, 印環細胞癌を認め, 粘膜下に GCP を伴い, リンパ節転移は認めず, T1N0 stageIA であっ た.【考察】浸潤・発育の過程で分化度が変化し組織型が多様 化すると考えられるが, 本例ではほぼ同時期の独立した発癌 形式の存在が推察され，GCP の発癌への関与も考えられた. 【結語】早期癌でも多彩な組織形態を示す症例もあり, 術前の 厳密な内視鏡診断と術後の厳重な経過観察が必要である. 
PC-1-057 StageIV 胃癌切除術後 1 年以上生存例の検討

加々良尚文, 青木太郎, 小林研二, 辻野 督, 小山太一, 関 洋介, 請井敏定, 上村佳央, 宮内啓輔, 金子 正 （近畿中央病院外科）

【目的】StageIV 胃癌切除術後の 1 年以上生存例を中心と し予後因子を検索する.【対象】胃癌手術 889 症例（19831999）のうち，取り扱い規約 12 版による stageIV 胃癌切 除 93 例.【方法】93 例を 1 年以上生存 35 例 ; L 群, 1 年未 満 58 例； S 群に分けた. $\mathrm{L}: \mathrm{S}$ 両群間で，1.t2 以上と $\mathrm{t} 3$ 以上, 2. $\mathrm{n} 2$ 以下と $\mathrm{n} 3$ 以上, $3 . \mathrm{P}-$ と,$+ 4 . \mathrm{H}-$ と,+ 5. 組 織学的分化型と末分化型, 6 . 根治度 B と C, について $\chi^{2}$ 乗検定により比較した.【結果】 $1 . \mathrm{t} ; \mathrm{p}=0.8291,2 . \mathrm{n} ; \mathrm{p}=$ $0.0546,3 . \mathrm{P} ; \mathrm{p}=0.3790,4 . \mathrm{H} ; \mathrm{p}=0.9999,5$. 分化度 $; \mathrm{p}=$ $0.0041,6$. 根治度 $; p=0.0081$. Kaplan-Meier 法による生存 率を同様の 2 群間で比較した結果, $1 . \mathrm{t} ; \mathrm{p}=0.9342,2 . \mathrm{n}$; $\mathrm{p}=0.0250,3 . \mathrm{P} ; \mathrm{p}=0.3261,4 . \mathrm{H} ; \mathrm{p}=0.4348,5$. 分化度 $; \mathrm{p}$ $=0.0060,6$. 根治度 $; \mathrm{p}=0.0029$ であった.【結論】 StageIV 胃癌切除症例ではリンパ節転移が 2 群以内, 組織学的分 化型症例は予後が比較的良好であり，根治度 B の手術に より予後改善が期待できると考えられた。

PC-1-058 AFP 産生胃癌の臨床病理学的検討と新たな 治療戦略

末廣敬祐, 梨本 篤, 藪崎 裕

(新潟県立がんセンター新潟病院外科)

AFP 産生胃癌の臨床病理学的特徴を明らかにし, 新たな治療 戦略について考察することを目的とした. 2000 年末までに初発 手術胃癌のうち, 術前の血清 AFP 值が $20 \mathrm{ng} / \mathrm{ml}$ 以上で, 慢性肝 機能障害, 肝硬変を除いた 45 例を対象とし, 臨床病理学的検討 を行った.【結果】血清 AFP 值 ; 平均 3091ng/ml, 中央值 104.35 $\mathrm{ng} / \mathrm{ml}$. 組織型 ; 分化型 20 例，未分化型 25 例であり, T1, T2 15 例, T3 23 例, T4 4 例, N0 3 例, N1 以上 42 例であった. P 033 例, P1 12 例であり, 肝転移は同時性 13 例, 異時性 11 例で あった. 42 例 $(93 \%)$ に胃切除術が施行され，22 例 $(49 \%)$ に 治癒切除が施行された. 5 生率は, 治癒切除 $33.8 \%$, 非治癒切除 $0 \%$ であった，治癒切除 22 例のうち，50\%に肝転移，9\%にリ ンパ節再発が出現した. 5 生率は 5 例で, 2 例に肝動注療法が施 行されていた. 血清 AFP 值と予後は相関しなかった.【結語】予 後因子としては，P因子と $\mathrm{H}$ 因子が挙げられる. 当科の方針と して術前検査で P1 が疑われた症例は, staging laparoscopy 施 行し, P1の場合は手術せず, 化学療法を選択する. H1 に対して は, 術前に動注も含めた術前化療を選択する.
PC-1-059 有荎性に壁外性の発育をした胃原発・巨大 Gastrointestinal stromal tumor の 1 手術例 鈴木宏光, 松本英男, 土肥俊之

\section{（土肥病院外科）}

【はじめに】有茎性に壁外性の発育をした胃原発・巨大 Gastrointestinal stromal tumorの 1 例を経験したので報告す る.【症例】77 歳男性. 腹部膨満感を主訴に来院し, 触診にて 臍上に小児頭大の腫瘤を認めた. 腹部超音波検査で $20 \mathrm{~cm}$ 大の境界明瞭な cystic mass としてとらえられ，さらに肝 S 4 に接する $18 \mathrm{~mm}$ 大の境界不明暸な low echoic mass を認 めた. MRI ではどちらの腫瘤も腹腔内臓器との連続性は確 認できなかった. 以上の所見より腹膜由来の腫瘍を想定し, 摘出術を予定した.【手術】小坚頭大の腫榴は網襄内に胃前 庭部後壁より, 肝 S4 に接していた腫瘤も胃前庭部小彎側か ら胃壁に連続して有茎性に壁外性に発育していた，免疫組 織化学的染色では, 抗 desmin 抗体, 抗 $\alpha$-smooth muscle actin 抗体陽性であり, 平滑筋肉腫と診断された.【結語】本症 例は有茎性に壁外性の発育を呈する珍しい増殖傾向を示し ており, 術前画像診断にて腹腔内臓器との連続性を確認で きなかった. 同様な報告が他にも見受けられており，本疾患 を考慮した鑑別診断を心がける必要があると思われた。

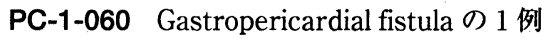

奥野敏隆, 市川未絵, 石川 泰, 京極高久, 高峰義和, 林 雅造

（西神戸医療センター）

【はじめに】食道裂孔ヘルニアに,あるいはそれに対する Nissen fundoplication 施行後の再発において稀に Gastropericardial fistula が 起こるとの報告がある. 致死率は $50 \%$ 以上とされており，予後不良 の病態である. 我々は早期診断と適切な全身管理, 手術により救命 できた 1 例を経験したので報告する.

【症例】 69 藏, 男性. 胸痛と動悸を主訴に救急外来を受診した. 頻 脈 (心拍 120 回/分) と著明な貧血 (ヘモグロビン值 : $4.4 \mathrm{~g} / \mathrm{dl}$ ) を認 めた. さらに心電図, 胸部 X 線, 心エコー所見から心筋梗塞あるい は心筋炎による心不全と診断, 緊急入院となった. 入院後, 大量の 吐血を来たしたため緊急内視鏡検査を行った. 大きな食道裂孔へル ニアを認め, さらに胃体部小弯に心外膜に穿通した直径 $5 \mathrm{~cm}$ の潰 瘍を認めた. Gastropericardial fistula と診断, 抗潰瘍剤投与ととも に循環，呼吸管理により全身状態を改善せしめたのち,すみやかに 手術を施行した. 右下半側臥位とし, 左第 7 肋間にて開胸した. 術 前の心エコーにて心外膜と心の瘾着が疑われたため, 潰瘍底をその ままに胃を心外膜より剥離した. 経横隔膜的に噴門側胃切除を施 行, 食道と残胃との端側吻合を行った. 術後経過は良好である. 
PC-1-061 同時性胃二重癌を呈したCA19-9 産生胃癌の 一例

山本将士, 平岡邦彦, 竹山宜典, 大野伯和, 生田 肇, 具 英成, 黒田嘉和

(神戸大学医学部第一外科)

【症例】77 歳女性. 家族歴は特記すべきことなし. 現病歷，現症 および検査所見 2001 年 11 月, 嘔吐を主訴に当院受診. 上部消 化管内視鏡にて 2 型病変による幽門部完全閉塞をみとめ, また 噴門部直下前壁に IIc 病変をみとめた. 同時性胃二重癌と診断さ れ, 入院となった. 腫敬マーカーは CA19-9 は $1088 \mathrm{U} / \mathrm{ml}$ と著明 に高值であった。 下腹部 CT にて径約 $4 \mathrm{~cm}$ の右卵巣襄腫をみと めた。手術㧍よび切除標本所見 胃全摘術, D2リンバ節郭清術, 胆㖶摘出術, 右付属器切除術を施行した. 病理診断では幽門部病 変は一部に粘液貯留像をみとめた。噴門部病変は tub2 であっ た. 免疫組織学的には幽門部病変はCA19-9 抗原陽性であった が, 噴門部病変では陰性であった。血中 CA19-9 值は術後 18 日目 に $72 \mathrm{U} / \mathrm{ml}$ と低下し, 術後 31 日目には $30 \mathrm{U} / \mathrm{ml}$ と正常化した。 【考察】本例は噴門部の早期癌と幽門部の進行癌の同時性胃二重 癌を呈していたが, CA19-9 免疫染色では幽門部胃癌のみ陽性で あり，一部に粘液貯留像がみられた. CA19-9 産生胃癌本邦報告 例 11 例のうち 2 例に粘液癌が報告されている. 粘液貯留が $\mathrm{CA}$ 19-9 産生胃癌の特徵の一つである可能性が示唆された。

PC-1-062 所属リンパ節にサルコイド反応を伴った胃小 細胞癌の 1 例

高野 学, 秋山裕人, 宮本 修, 小野 要

（稲沢市民病院外科）

胃小細胞痹は比較的まれであり，予後不良な症例が多い，ま た悪性腫場の所属リンパ節にサルコイド結節を認めることが ありサルコイド反応と呼ばれている.われわれは所属リンパ節 に著明なサルコイド反応を認めた胃小細胞癌の 1 例を経験し た. 症例は 74 歳の男性で, C 型慢性肝炎で当院通院中であっ た. 平成 11 年 8 月上腹部不快感が出現し, 上部消化管造影, 内 視鏡検查にて胃前庭部小弯側に周堤を伴う腫腸を指摘され，幽 門側胃切除術を施行した。切除標本上 $4.0 \times 2.5 \mathrm{~cm}$ の 2 型の腫瘍 で, 病理組織学的所見で小細胞癌と診断された. 進達度はss で幽門上リンパ節に転移を認め, 所属リンパ節に類上皮細胞お よび多核巨練胞からなるサルコイド反応がみられた. 術後経過 は良好で術後 2 年無再発生存中である. 胃小細胞癌は早期から 脈管および静脈浸襲をきたすため遠隔転移が多く，ほとんどの 症例は手術時あるいは手術後早期に転移が認められ，1 年以内 に死亡している. 予後不良な胃小練胞癌に予後良好の徴候であ るサルコイド反応を認めた報告例は少なく，2 年無再発である ことも含めて極めてまれな症例と考えられ報告する.
PC-1-063 十二指腸球部に嵌頓し大量出血を繰り返した 胃 GIST の一例

野地みどり, 加藤俊夫, 入山拓平, 毛利智美, 福浦竜樹, 伊藤佳之

（同心会遠山病院外科）

胃体上部の GIST が十二指腸球部に逸脱陥入を繰り返し，大 量出血を来した症例を経験したので報告する. [症例] 71 歳, 男 性. 平成 13 年 11 月 8 日上腹部痛, 黑色便を主訴に来院し, 精査 治療目的で入院した.内視鏡検查では胃体上部後壁に delle を 伴った粘膜下腫瘍を認めたが明らかな出血は認めなかった。 上 部消化管透視, CT では胃体上部後壁に径約 $5 \mathrm{~cm}$ の内腔に突出 した粘膜下腫瘍が描出された. 入院後 4 回, 大量の黑色便と筫血 の進行を認め, その都度 NG チューブ挿入, あるいは胃内視鏡検 查を施行するも胃内に出血は認めなかった. $\mathrm{CF}$, 小腸透視, 腹 部血管造影, 出血シンチも施行したが出血源は同定できなかっ た. 術前の確診は得られなかったが, 胃粘膜下腫場が出血源と考 え手術を施行した. 開腹時所見で, 胃体上部後壁の粘膜下腫瑒が 十二指腸球部に逸脱嵌入しており, これを環納し噴門側胃切除 を行った. 腫瘍の免疫組織染色では vimentin, CD34, c-kit 蛋白 陽性, ASMA, desmin, s-100 蛋白陰性で, GIST uncommitted type と診断した. 本例では, 胃 GIST が十二指腸陥入時にのみ 出血を来たし，特異な病態を呈したものと推察された.

PC-1-064 当院における胃癌リンパ節転移個数少数例の 検討

富田晴久, 市川大輔, 上島康生, 城野晃一, 塩飽保博, 濱 島高志, 李 哲柱, 池田栄人, 武藤文隆, 栗岡英明 （京都第一赤十字病院外科）

【目的】当院におけるリンパ節転移個数少数例の解析から, 早 期胃癌症例の sentinel node (SN) navigation surgery の妥当 性について検討した.【方法】D2 以上の郭清を伴った胃癌症 例で, リンパ節転移個数 1 から 3 個の症例の臨床病理学的因 子とリンパ節転移部位について検討した. 【結果】リンパ節転 移 1 個の症例は 49 例 $(5.3 \%)$ で, 深達度は $\mathrm{sm} 16$ 例, $\mathrm{mp} 8$ 例, ss 12 例及び se 以深 13 例であった. 部位別に U 領域では 1 群転移 $66.7 \%, 2$ 群転移 $33.3 \%, \mathrm{M}$ 領域では 1 群 $94.1 \%, 2$ 群 $5.9 \%, \mathrm{~L}$ 領域では, 1 群 $87.0 \%, 2$ 群 $13.0 \%$ であった. 早 期癌のみの検討では, 対側転移を $25 \%$ に認めた。早期癌の転 移 2 個及び 3 個症例を $\mathrm{SN}$ 転移及び次の転移と考えると, 同 部位リンパ節複数個転移症例が 5 例あったが, 3 例で異なる リンパ経路への転移を認めた.【結語】特に $\mathrm{U}, \mathrm{L}$ 領域に関し ては, 胃癌の SN は, 必ずしも腫瘍近傍とは限らず, 症例に 応じた SN mapping の重要性が示唆された．また，SNに転 移を認めた場合, 別のリンパ経路を介して転移する症例もあ り，2 群に準じた郭清が必要と思われた。 
PC-1-065 早期胃癌とリンパ節転移

梶原啓司, 德永隆幸, 森永真史, 黒崎伸子, 君野孝二, 飛 永晃二

（健康保険諫早総合病院外科）

【目的】術前術中における深達度及びリンパ節転移の有無 の診断精度には限界があり, 縮小手術 $\mathrm{A}$ は慎重な適応決 定が必要である.【方法】多発癌, 残胃癌を除く早期胃癌切 除症例 406 例を対象とた.【結果】(1) $\mathrm{m}$ 癌 225 例, $\mathrm{sm}$ 癌 181 例で, $\mathrm{m}$ 癌で 2 例 $0.9 \%, \mathrm{sm}$ 癌で 26 例 $14.4 \%$ にリンパ 節転移を認めた. sm 癌の 8 例に 2 群リンパ節に転移を認 めた. $\mathrm{m}$ 癌の転移例は陥凹型であった. (2) 腫瘍径 0-10mm で $2 / 48$ 例 $4.2 \%, 10-20 \mathrm{~mm}$ で $2 / 95$ 例 $2.1 \%$ の転移率で あった. $20 \mathrm{~mm}$ 以下の 1 例に 2 群リンパ節転移を認めた. (4) 組織型では高分化型 4/150 例 $2.7 \%$, 中分化型 $11 / 113$ 例 $10.7 \%$, 未分化型 $13 / 153$ 例 $8.5 \%$ の転移率であった. (5) 腫瘍径 $20 \mathrm{~mm}$ 以下でも高分化型 $1.6 \%$, 中分化型 $3.6 \%$, 低 分化型 3.7\% の転移率で, 陥凹型では各組織型で転移を認 めた. 高分化の隆起型 41 例では転移を認めなかった.【ま とめ】(1) 腫瘍径 $20 \mathrm{~mm}$ 以下の症例でも 4 例 $2.8 \%$ に転移 を認め 1 例は 2 群リンパ節に転移を認めた. (2) 高分化で 隆起型の症例が縮小手術 A の適応と考えられた.

PC-1-066\#10・\#11リンパ節転移からみた胃癌に対 する胃全摘・㬸あるいは脾合併切除症例の検討 本多 博, 小針雅男, 土屋 誉, 赤石 敏, 内藤 剛, 竹 村真一，生澤史江，杉山慎一郎

（仙台市医療センター仙台オープン病院外科）

【目的】胃癌の胃全摘術で LN 郭清目的に萭 or 脾切除が併施される が, \#10,11LN 転移の有無から, 切除の必要性と温存の可能性を検討. 【方法】平成 7 13 年の 7 年間の当科の胃癌に対する胃全摘施行 397 例中, 蓃 or 脾合併切除 207 例を対象に, LN 転移 - 壁区分・深達度・ 腫場径等を検索. [結果】術式 : 脾摘 42 例 (\#10 郭清), 脾動脈切除・ 脾摘 37 例及び荤尾僛切除 128 例 (\#10,11 郭清), 深達度: $\mathrm{m} / \mathrm{sm} /$ $\mathrm{mp} / \mathrm{ss} / \mathrm{se} / \mathrm{si}=3 / 20 / 15 / 59 / 79 / 31$ 例. \#10orl1 転移は 47 例 (23\%). \# 10 のみ転移は 10 例で, $\mathrm{mp} / \mathrm{ss} / \mathrm{se} / \mathrm{si}=1 / 1 / 6 / 2$ 例, 全例で術中に 1 群 LN 転移を認識. 1例を除き大彎側優位も, \#4sa, b 転移 6 例に対 し全例＃1，3，7何れかに転移あり.\#11のみ転移は 16 例で, ss/se/si $=7 / 7 / 2$ 例, 全例腫瘍径 $\geqq 4 \mathrm{~cm}$. 小弯側優位が 10 例で; 1 例を除き \# $1,3,7$ 何れかに転移あり，ほぼ全例で術中に認識. \# 10, 11 共に転移は 21 例で, ss $/ \mathrm{se} / \mathrm{si}=2 / 10 / 9$ 例, 全例腫瘍径 $\geqq 7.0 \mathrm{~cm} .1$ 例を除き\# $4 \mathrm{sa}$, $\mathrm{b}$ 転移あり, 3 例を除き\# $1,3,7$ の何れかに転移あり，ほほ全例で術中 に認識された.【結語】 $\leqq \mathrm{mp} \cdot$ 腫瘍径 $\leqq 4 \mathrm{~cm} \cdot \mathrm{N} 0$ 症例の脾温存の妥当 性, 小弯の腫瘍径 $\geqq 4 \mathrm{~cm} \cdot$ 小弯側 $\mathrm{LN}$ 転移例の\# 11 郭清並びに腫瘍径 $7 \mathrm{~cm}$ 以上・ $\mathrm{N} 1$ 症例の脾摘・ \# 11 郭清の必要性が示唆された.
PC-1-067 TS-1 + CDDP 療法が奏効した進行胃癌の 2 例

桜井真人, 武冨紹信, 二宮繁生, 古賀 聡, 吉田隆典, 矢 野篤次郎, 松股 孝

(中津市民病院)

【症例 1】42 歳, 男性, 胃体下部〜前庭部の小弯前壁側の 2 型進 行癌及び多発性肝転移に対し, 幽門側胃切除術 +肝右三区域切 除を行った. 総合的進行程度は pT3, pN1, sP0.pH1, sM0, fStageIVであった. 術後 1 ケ月後の CT にて多発性肝転移, 右 肺転移及び LDH の上昇を認め, TS-1 (80mg/body, day1 21) +CDDP (60mg/body, day8) 療法を 5 クール行った. CT 上多 発性肝転移及び肺転移は著明に縮小し, LDH の低下も認め, PR と判断した. 【症例 2】78 歳, 男性, 胃体下部小弯側の 2 型進行癌, 肝両葉にわたる多発性肝転移及び傍大動脈りンパ節腫大を認め た. 切除不能進行胃癌と判断し, TS-1 (100mg/body, dayl 21) $+\operatorname{CDDP}(60 \mathrm{mg} /$ body, day8) 療法を 2 クール行った. CT 上多 発性肝転移，傍大動脈リンパ節腫大ともに縮小し, PR と判断し た.【まぬ】高度進行胃癌に対する TS-1 + CDDP 療法にて, い ずれの症例も PR を得ることができた. Grade2 以上の有害事象 は出現しなかったため, CDDP 投与前後 3 日間以外は QOL を 保ちつつ外来にて施行可能であった. 高度進行胃癌に対して, TS-1 + CDDP 療法は安全かつ有効であると考えられる.

PC-1-068 Second line としての Weekly Taxol が奏効し た胃癌転移による癌性リンパ管症の 1 例

芳賀紀裕, 福田敬宏, 巟嶋高寛, 河野至明, 外村修一, 橋 本信次

（群馬県立がんセンター）

今回我々は TS-1 が無効で肺の癌性リンパ管症を合併し たため second line として weekly Taxol 療法を施行し著 効が見られた症例を経験したので報告する. 症例は 36 歳, 女性. 4 型胃癌で骨盤内に腹水を認めたため化学療法を選 択し平成 13 年 7 月 23 日より TS- $180 \mathrm{mg} / \mathrm{day} 4$ 週 2 休に よる治療を開始した. 3 クール施行したが大動脈周囲リン パ節転移出現し効果はPDであった．また咳嗽出現し平成 13 年 11 月 29 日入院, 胸部単純 X-P および胸部 CTにて 画側のすりガラス状陰影および右下葉を中心とした肺胞 硬化像を認めた。平成 13 年 12 月 7 日 TBLB 施行し癌性 リンパ管症と診断され, 12 月14 日より second line として Taxol $120 \mathrm{mg}$ の weekly 投与を開始した. 2 週投与後咳嗽 軽減し, 画像上も癌性リンパ管症の著明な改善を認めた. また Taxol weekly 投与前に高值を示した LDH，CA125 も低下した. Performance status が 3 から 1 へ改善したた め平成 13 年 12 月 28 日退院となり平成 14 年 2 月 27 日現 在も外来にて Taxol weekly 投与継続中である. 
PC-1-069 当科の胃癌に対する腹腔鏡補助下幽門側胃切 除術（LADG）の手術手技と臨床病理学的検討

木村正之, 牧角良二, 瀬田真一, 高橋克之介, 伊崎友利, 竹村和郎, 山口 晋

(聖マリアンナ医科大学消化器外科)

【目的】胃癌に対して腹腔鏡補助下幽門側胃切除術（LADG）を施行 したのでその手術手技と臨床病理学的検討について報告する. (対 象】術前に早期胃癌と診断された 15 例. 平均年令 56 (25〜 73) オ. 男性 8 例, 女性 7 例. 占拠部位 L が 12 例, $\mathrm{M}$ が 3 例. 肉眼型は $1 \mathrm{lc}$ が 12 例, llc + lla が 1 例，llc + lll が 1 例，1が 1 例. 組 織型は tubl が 3 例, tub2 が 5 例, por が 3 例, sig が 3 例, pap が 1 例. 郭清度 は D1 $+\alpha$ が 4 例，D2 が 11 例. 【手術手技】トロッカーは 5 本使用し た $(10 \mathrm{~mm}$ を 1 本と $5 \mathrm{~mm}$ を 4 本). 郭清は $4 \mathrm{sb} \rightarrow 4 \mathrm{~d} \rightarrow 6 \rightarrow 14 \mathrm{v} \rightarrow 8 \mathrm{a} \rightarrow 11$ $\mathrm{p} \rightarrow 7 \rightarrow 9 \rightarrow 5 \rightarrow 12 \mathrm{a} \rightarrow 1 \rightarrow 3$ の順に en bloc に行なった. 上腹部正中に 4 $\sim 5 \mathrm{~cm}$ の縦切開にて開腹後胃を脱転し病巣を含めた D2 郭清を伴う 幽門側胃切除を施行した．再建は器械吻合にて Billroth l 法とした。 【結果】平均手術時間 329 (195 545) 分. 平均出血量 180 (100 280) $\mathrm{ml}$. 病理診断は $\mathrm{m}$ が 7 例, sm が 6 例, ss が 2 例. 平均郭清リンパ節 個数は $31(13 \sim 50)$ 個. 合併症は縫合不全が 1 例, 吻合部狭窄が 1 例. 【結論】腹腔鏡補助下幽門側胃切除術は従来の開腹手術に比較して長 い手術時間を要するが, 術後の QOL は極めて良好であり今後は症例 を選択すれば十分に容認できる可能性があると考えられた。

PC-1-070 十二指腸球部に脱出した胃多発ポリープ癌に 対し腹腔鏡補助下胃切除（LADG）を施行した 1 例 水口真二郎 ${ }^{1}$, 弓場健義1", 山崎芳郎 ${ }^{11}$, 福井雄一"1, 黄 泰平 ${ }^{11}$,

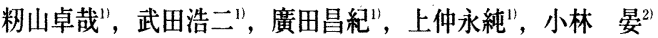
(大阪厚生年金病院外科 ${ }^{11}$, 大阪厚生年金病院病理科 ${ }^{21}$ )

胃ポリープ病変は時に十二指腸球部に脱出し, ball valve syndrome (BVS) を引き起こす，今回，我々は球部に脱出した 胃多発ポリープ癌に対し, 腹腔鏡補助下胃切除（LADG）を施 行した 1 例を経験した. 症例は, 70 歳女性. 主訴は両下肢の浮 腫，低蛋白血症及び貧血．家族歴では父に胃癌．腹部超音波検 查で肝門部に径 $50 \mathrm{~mm}$ 大の mass を認め，内視鏡検査にて，体 下部小弯から幽門輪にかけて基部を有する巨大な Ip 型病変を 認めた. 腫瘍先端は球部に陥入し，鉜子にて旁引するも還納は 不可能であった. 生検にて高分化型腺癌を認め，遠隔転移，リ ンパ節腫大を認めず，早期胃癌と診断.内視鏡的切除は困難と 判断し，LADG，リンパ節郭清 $(D 1+\beta)$ を施行した．切除標本 では, 計 4 個の Ip 型病変を認め, 各々から高分化型腺癌を認め るも，連続性は認めず。腫瘍径は $1.5 \mathrm{~cm}$ から $4.0 \mathrm{~cm}$ の範囲で,

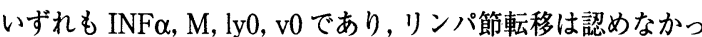
た。本邦でも胃覀性腫瘍の球部への脱出は報告されているが， 本症例のように複数個のポリープ病変が同時に脱出した報告 は非常に稀であり，若干の文献的考察を加えて報告する。
PC-1-071 新しいイレウスチューブの開発, 使用の経験

上泉 洋 ${ }^{1)}$, 阿部憲司 ${ }^{11}$, 伊藤浩二 ${ }^{1)}$, 生田圭司 ${ }^{2)}$, 皆川の ぞみ”

(岩見沢市立総合病院外科 ${ }^{1)}$, 北海道大学第一外科 $\left.{ }^{2}\right)$

【目的】苦痛を軽隇し，確実に挿入可能なイレウスチューブ (以 下チューブ）を開発する.【従来の問題点】幽門輪を越えても十 二指腸球部に当たり，下降脚に進んでいかず胃でとぐろを巻 く. 小腸の屈曲部や Kerckring 譬に引っかかりそれ以上進まな くなる.【チューブの製作・使用法】これらの問題は幽門輪を越 えるように工夫された錘の入った誘導子にある. 誘導子にもバ ルーン（誘導子バルーン）をつけた，ダブルバルーンを作成し た。幽門輪から進まない場合，誘導子バルーンを膨らませ チューブを少し引き抜きストレート化し，再びチューブを挿入 する．小腸で進まなくなった場合も誘導子バルーンを膨らま せ，チューブを挿入する．最後に誘導子バルーンを虚脱させ， 後方にあるバルーンを膨らませる.【結果】7例に新チューブを 用いた. 6 例は従来のチューブで不成功だったもので, 5 例は難 なく挿入に成功したが，1例は幽門輪に引っかからず不成功 だった. 残り 1 例は最初から新チューブを用い挿入時に小腸の かなり奥まで挿入出来, 劇的に症状の改善をみた.【結語】誘導 子バルーン付きイレウスチューブは非常に有用である。

PC-1-072 上腹部手術における被覆, 充填組織としての 肝円索グラフトの使用経験

長浜雄志 ${ }^{1)}$, 丸山道生 ${ }^{1)}$, 馬場裕之 ${ }^{2)}$, 夏井信輔 ${ }^{1)}$, 落合高 徳 ${ }^{1}$, 長谷川久美 ${ }^{1)}$, 高島 格 ${ }^{1}$, 片田雅孝 ${ }^{11}$, 江淵正和 ${ }^{1}$ (東京都立大久保病院外科 ${ }^{1}$, 化学療法研究所附属病 院 ${ }^{2)}$

我々は肝円索を遊離し有茎グラフトを作成して開腹術の際の 組織被覆, 充填に用いている. 対象) 当科において行われた胃十 二指腸潰瘍穿孔 51 症例の穿孔部充填, 総胆管切開 13 症例の胆 道ドレナージ Tube の被覆に肝円索を用いた手技を行った，方 法)肝円索を腹壁より切離し, 門脈臍部にて肝に連続した有茥グ ラフトを作成する．潰瘍穿孔症例にはグラフトを穿孔部に充填 する． 総胆管切開症例にはドレナージTube をグラフト内に貫 通させて被覆する. 結果) 潰瘍穿孔例では横隔膜下膿瘍 1 例潰瘍 部出血 1 例をのぞき順調に経過した．胆道ドレナージTube 抜 去に伴う腹痛などの合併症は認められなかった. 考察)肝円索グ ラフトは，胆道十二指腸領域に容易に到達可能な被覆充填材で あった．組織欠損の大きい胃潰瘍には十分な効果を示さなかっ たが，十二指腸潰瘍穿孔には有用であった，総胆管切開後の Tube 被覆に関しては肝円索グラフトを用いることで抜去後の 腹痛, 腹膜炎は予防可能であり, Tube 抜去に要する期間も短縮 した. 結語) 肝円索グラフトは十二指腸胆道領域手術における容 易に作成可能かつ有用な組織被覆充填材であった。 
PC-1-073 門脈ガス血症をきたした nonocclusive mesenteric ischemia 1 例 小島由光 ${ }^{1,2)}$, 鈴木昌八 ${ }^{2)}$, 中村 達 $^{21}$

$\left(\right.$ 二川病院 ${ }^{1)}$, 浜松医大第二外科 $\left.{ }^{21}\right)$

【はじめに】門脈ガス血症をきたした nonocclusive mesenteric ischemia (非閉塞性腸管虚血症)の 1 例を救命できたので報告する. 【症例】 53 才, 男性. 下痢の後の腹部膨満に対して近医で浣腸と腸 蠕動促進剤の点滴を受けた後, 腹痛および湢吐をきたし腸閉塞の疑 いで入院. 腹部は弱い圧痛を認めるのみで, 血液検査では炎症所見 を認めたがアシドーシスはなかった. 腹部超音波検査で肝内門脈に ガスを認め, 腹部 CT 検査でも近位小腸が拡張し門脈ガスが存在し たが, 上腸間膜動静脈は良好に造影された。このため, 保存的治療 を試みたが徐々に腹膜刺激症状が出現しアシドーシスをきたした ため, 発症 18 時間後に開腹術を行った. 開腹所見では Treitz 勒帯 直後から約 $1 \mathrm{~m}$ の空腸が壊死しており，切除吻合した. 病理学的に は出血性壊死がみられたが, 血栓, 血管炎等の特異な所見を認めず, 脱水と腸管の蠕動立進を背景とした非閉塞性腸管虚血症と診断し た.【まと】腸管壊死を伴う門脈ガス血症は死亡率 $65 \%$ と予後不 良である.上腸間膜動静脈に器質的な障害のない非閉塞性腸管虚血 症においても，門脈ガス血症を呈する症例を救命するためには，時 期を失することなく開腹術を行うことが重要である.

PC-1-074 放射線治療後の放射線性腸炎の治療：特に婦 人科領域に関して

中島秀彰 ${ }^{11}$, 森恵美子 ${ }^{1)}$, 山本一治 ${ }^{1)}$, 岡 武志 ${ }^{11}$, 福田篤 志"), 松田裕之 ${ }^{11}$, 松浦 弘 ${ }^{11}$, 岡留健一郎 ${ }^{1}$, 森 正樹 ${ }^{2)}$

(済生会福岡総合病院外科 ${ }^{1}$, 九州大学生体防御医学研究 所腫瘍外科 ${ }^{21}$ )

【目的】放射線治療後に生じた放射線性腸炎に対する治療 法について検討した.【対象と方法】婦人科領域の悪性腫 瘍への放射線治療後の放射線性腸炎で入院治療した 18 例を対象とした.【結果】外科的治療 (S) 群 15 例と保存的 治療 (C) 群 3 例の比較では，腸閉塞が $\mathrm{S}$ 群に多い傾向が 見られた. 全 18 例の死亡率は 4/18 例 $(22 \%)$. S 群の死亡 率は 4/15 例 (26\%), C 群の死亡例はなかったが, S 群と $\mathrm{C}$ 群では死亡率に有意差はなかった. S 群の生存 11 例と 死亡 4 例について比較検討したが，有意差を認める要因 はなかった，術式の検討ではバイパス術の 4 例に死亡例 は無かったが, 腸切＋再建の 7 例では 2 例 $(28 \%)$ が死亡 した. また, 術後死亡した 4 例の死因は, 癌再発が 2 例, 敗血症が 1 例, 腸閉塞から穿孔を生じ緊急手術後に術死 した症例が 1 例であった.【結語】1）腸閉塞を呈する放射 線性腸炎は穿孔を起こす前に積極的に手術を行うこと， 2）全身状態不良例や腸管癒着が強い例ではバイパス手術 も考慮すること，が示唆された。

\section{PC-1-075 診断に苦慮した大動脈十二指腸㾇の 1 例}

大平真裕, 三浦義夫, 山木 実, 多本法生, 沖山二郎, 先 本秀人, 江藤高陽, 高橋 信

(中国労災病院外科)

80 歳男性, 平成 8 年腹部大動脈瘤 $\mathrm{Y}$ グラフト置換術の既 往. 平成 14 年 1 月 9 日大量の吐下血で近医入院，原因不 明で下血繰り返すため 2 月 12 日当院内科へ緊急入院. 出 血シンチにて左上腹部に集積を認め右下腹部へ移動し た.内視鏡，血管造影，CT では出血源不明であった． 2 月 16 日大量下血で出血性ショック状態となり緊急開腹 し, 術中内視鏡にて十二指腸からの動脈性の出血を確認 して十二指腸とグラフトの一部を切除し，それぞれを縫 合閉鎖した. 3 月 2 日胃管より出血あり内視鏡下に十二指 腸潰瘍出血を確認し，止血術を繰り返すも 3 月 9 日 ショック状態となり手術施行. 潰瘍縫縮するも十二指腸 内に瘦孔を認め姑息的に縫縮したが, 3 月 13 日死亡した. 病理解剖より大動脈前面に血腫を作り十二指腸後壁を圧 迫した結果潰瘍, 瘦孔ができたと推測された. 大動脈消化 管瘦は稀であるが腹部大動脈瘤手術後の重大な合併症の ひとつであり，心血管外科医のみならず消化器外科医も 周知しておく必要があると思われた.

\section{PC-1-076 十二指腸カルチノイドの検討}

村瀬勝俊, 角 泰廣, 澤田 傑, 吉田直優, 松山隆生, 松 嶋麻子, 藤田 基, 西脇 進, 毛利智好, 尾関 豊 (国立東静病院外科)

【はじめに】十二指腸カルチノイドは比較的まれな疾患である. 当科で経験した十二指腸カルチノイド 4 例につき文献的考察を 加え報告する. (症例】男性 3 名, 女性 1 名で平均年龄は 68.3 歳で あった. 上部消化管内視鏡で偶発的に発見されたものが 2 例, 胃 切除に伴い偶発的に発見されたものが 1 例, 食欲不振の精査で 発見されたものが 1 例であった. 腫瘍の局在は十二指腸球部が 2 例で下行部が 2 例であった. 肉眼型は Ip 型が 1 例, Isp 型が 2 例, I 型が 1 例であった. 術前腫瘍が確認されていた 3 例のうち 2 例は術前カルチノイドの診断がなされていた. 手術時カルチノ イドの診断が判明していた 3 例に対する術式はそれぞれ十二指 腸ポリープ切除術, 十二指腸部分切除術 (楔状切除術), 幽門輪 合併十二指腸部分切除術であった. 腫瘍の最大径は $10 \mathrm{~mm}, 13$ $\mathrm{mm}, 15 \mathrm{~mm}, 25 \mathrm{~mm}$ で, 壁深達度はそれぞれ sm, sm, sm, mp であった. 全例とも術後再発徴候は認めていない.【結語】(1)大 きさ $1.5 \mathrm{~cm}$ 以下で壁深達度 $\mathrm{sm}$ と考えられる症例は基本的に局 所切除でよいと考えられる. (2) $1.5 \mathrm{~cm}$ 以上で $\mathrm{mp}$ に達している 症例でも全身状態を考慮した術式を選択すべきと思われた. 
PC-1-077 腹腔鏡下十二指腸部分切除を行った十二指腸 早期癌の 1 例

町田浩道, 平井栄一, 牛田進一郎, 鈴木一史, 吉田雅行, 戸田 央, 中谷雄三

(聖隷浜松病院外科)

十二指腸早期癌に対し内視鏡的粘膜切除術 (EMR) を施行した が, 病変の遺残を否定できず腹腔鏡下十二指腸部分切除を行ったの で報告する【症例】 64 歳男性. 十二指腸球部から下行部に隆起性病 変を認め EMR 施行. 7 力月後, 球後部に小隆起を認め再度 $\mathrm{EMR}$ 実施. 病理で乳頭腺癌を認め, 癌の遺残を否定できず追加切除のた め入院. 手術前, 内視鏡で切除部に止血用クリップを留置 (手術手 技】脚部, 心窝部, 右鎖骨中線上の助弓下 ・胎右方に計 4 力所トロッ カー留置. 漿膜面から病変は同定できず漿膜浸潤を疑う所見なし. リンパ節腫大もなかった. 術中内視鏡を行い内腔から病変を確認し た. 内視鏡下に吸引生検針 (オリンパス NA-11J-KB) を切除予定部 から漿膜側に貫通し, 生検針からナイロン糸をループ状に槳膜側へ 出した，腹腔内から絹糸をループにかけ十二指腸内に引き达んだ. 絹系を目印とし腹腔鏡下に吊り上げ糸をかけ，Endo-GIA で部分切 除実施. 手術時間 2 時間 49 分, 出血量 $25 \mathrm{~g}$. 病理検査で癌の遺残な し. 術後 4 日目に経口摄取開始, 7 日目に退院した【考察】EMR は全層切除ではなく深部断端遺残が否定できない場合がある. 全層 切除が可能な腹腔鏡下手術は，このような症例に対し有用である.

PC-1-078 十二指腸乳頭部癌に対する右胃動脈・迷走神 経幽門洞枝・十二指腸球部を温存した PpPD の意義 根本明喜, 五嶋博道, 東口高志, 池田 剛

\section{（尾鶁総合病院外科）}

(目的) 最近経験した十二指腸乳頭部癌 4 例に対して右胃動脈・迷走 神経幽門洞枝・十二指腸球部を温存した全胃幽門輪温存䐙頭十二指 腸切除術 (PpPD 機能温存型) III 型再建を施行したので報告. (対象 と方法) 年齢は $67-82$ 歳, 男 3 例, 女 1 例. 全例非露出腫瘤型で, 大 きさは $14.0 \mathrm{~mm}$, tub1, tub2, ly1, ly2 は 2 例ずつで, v0 は 1 例, v1 は 2 例, v2 は 1 例で, pancla は 2 例, panclb は 1 例, panc2 は 1 例 で, du2, du3 は2 例ずつ. $\mathrm{n}(-) 2$ 例, n1 (+) 1 例, n2 (+) 1 例で, $\mathrm{t} 2, \mathrm{t} 3$ は 2 例ずつで, stage 2 は 1 例で, 3 例は stage 3. これらと 䐙頭部領域癌 4 例に対する PpPD 従来型・III 型再建について検討. (結果) 1 . 予後：機能温存型で 82 歳, panc2, stage3 を含み 6 ヶ月か ら 2 年 3 ヶ月全例無再発生存中. $2 . \mathrm{NG}$ 抜去時期：機能温存型では 3.5 日, 従来型では 6.0 日. 3. 経口攝取開始時期：機能温存型では 4.5 日, 従来型では 7.0 日. 4. 体重減少率：術後 6 ヶ月目機能温存型で $4.1 \%$, 従来型は $6.5 \%$. 5.DAO 活性：従来型で低下傾向. 6. 血中 CCK 值 (経口脂肪負荷後)：機能温存型で上昇率が高値. (結語) 機能 温存型は従来型に比し, 遜色のない予後が期待でき, 栄養面や消化管 ホルモンからみても有用な術式となりうる可能性が示唆された.

\section{PC-1-079 十二指腸乳頭部腫瘍の治療戦略}

小林昭彦, 小西 大, 木下 平, 中郡聡夫, 井上和人, 小 田竜也, 高橋進一郎

(国立がんセンター東病院肝胆膵外科)

【背景と目的】当院における十二指腸乳頭部腫瘍の臨床病理 学的な特徴を調へその至適治療について考察する.【患者と 方法】1993 年 2 月から 2001 年 8 月までに当院で経験した 38 例の乳頭部腫瘍についてその臨床病理学的な検討を行った. 【結果】切除が可能であった 29 例のうち，2 例が adenoma， 3 例が carcinoma with adenoma, 24 例が carcinoma であっ た. 術式は局所切除が 2 例，十二指腸分節切除が 4 例，幽門 輸温存膰頭十二指腸切除が 24 例に対して行われた。 そのう ち局所切除 2 例, 十二指腸分節切除 1 例が切除断端陽性で あった.リンパ節転移を 15 例に認め全例 No. 13 に転位が認 められた. No. 16 転位例の予後は不良であった. 再発を 10 例に認め, 血行性再発のみ 5 例, 血行およびリンパ節再発が 4 例，局所再発が 1 例であった.【考察】十二指腸乳頭部腫瘍 に対する局所切除の対象は良性腫瘍と PDに耐術不能な悪 性腫瘍の症例に限り, その他の症例には $\mathrm{PD}+$ サンパ節郭清 が適当と思われた. No. 13 リンパ節が sentinel node ではな いかと考えられた．No. 16 の郭清の意義は認めなかった。

PC-1-080 原発性十二指腸癌 10 例と十二指腸乳頭部癌 の比較

阿部秀樹, 梅北信孝, 宮本幸雄, 真栄城剛, 井上 暁, 北 村正次

（東京都立墨東病院外科）

【目的】当科で切除された原発性十二指腸癌（以下，十二 指腸癌）を, 十二指腸乳頭部癌（以下, 乳頭部癌）と比較 し, 本腫瘍の特徴を明らかにした.【対象】1990年 6 月から 11 年間に, 当科で切除した十二指腸癌 10 例, 乳頭部癌 17 例を対象とした.【成績】診断の契機が十二指腸の通過障 害であった症例は乳頭部癌になく，十二指腸癌は 3 例で あった. 胆汁うっ滞の所見は，十二指腸癌が 3 例, 乳頭部 癌が 14 例で見られた．高分化型腺癌が占める割合は，十 二指腸癌が 3 例，乳頭部癌が 13 例であった.リンパ節転 移陽性例の予後は，十二指腸癌（5例）が乳頭部癌（5 例)に比べ良好な傾向があり，リンパ節転移陰性例では逆 に，乳頭部癌が有意に良好であった.リンパ節転移陽性例 のうち, 乳頭部癌は全例 $\mathrm{n} 2$ であるのに対して, 十二指腸 癌は $\mathrm{n} 1 ; 1$ 例, $\mathrm{n} 2 ; 2$ 例, $\mathrm{n} 3 ; 2$ 例であった.【まとめ】十 二指腸癌発見の契機は, 黄疸と通過障害で $60 \%$ となっ た. 組織型は高分化型が $30 \%$ であった。リンパ節転移陽 性例の予後は，乳頭部癌に比べ良好な傾向が見られた． 
PC-1-081 当院における非閉塞性腸間膜梗塞症手術症例 11 例の検討

矢部慎一，光吉 明，財間正純

（三菱京都病院外科）

【目的】非閉塞性腸間膜梗塞症（NOMI）は主幹動脈に器質的な閉 塞がないにもかかわらず，腸管虚血や壊死の生じる予後不良な疾 患である：当院で経験したNOMIについて検討した.【方法】対象 は手術にて NOMI と診断された 11 例(男 8 例, 女 3 例, 平均年齢 68.3 歳). (成績)心臟血管手術・カテーテル後 8 例, 腎透析 2 例, アルコール依存症 1 例と全例に基礎疾患を認めた. 初発症状は腹 部膨満, 腹痛, 嘔吐だった. 検査デー夕上昇は CRP8 例, CPK7 例, WBC6 例, LDH5 例, GOT/GPT3 例, AMY1 例に認めた. 発 症時診断はイレウス 5 例, 虚血性腸炎 3 例, 偽膜性腸炎 1 例, 腹膜 炎 1 例, NOMI1 例だった. 発症から開腹手術まで平均 4.1 日を要 していた. 術後 7 例が平均 13 日で死亡した(死亡率 63.6\%). 年龄 及び発症から開腹までの日数は死亡例と生存例で差を認めなかっ たが, 死亡例で腸管壊死が広範囲だった.【結論】上記の基礎疾患を 有する患者でイレウス様症状を生じたときはNOMIも疑い, 積極 的に腹部血管造影や試験開腹などを行う必要がある.そして NOMI と診断がつけば壊死腸管は切除せざるを得ないが, 基本的 には血管拡張剤の投与が治療の主体となると考えられた。

\section{PC-1-082 腹腔内遊離ガスを伴った腸管囊腫様気腫症の} 1 例

関根祐樹, 高津尚子, 福沢太一, 河合賢朗, 楠田和幸, 鈴 木 雄, 遠藤義洋, 北村道彦

（岩手県立胆沢病院外科）

[症例] 67 歳, 男性. 嘔気, 食欲不振を主訴に来院. 糖尿病, 高血 圧, 精神分裂病にて内服治療中. 来院時, 腹部は軟らかいが著明に 膨満, 圧痛なし. 来院時検査で白血球数 $8,300 / \mathrm{mm} 3, \mathrm{CRP} 12.2 \mathrm{mg} /$ $\mathrm{dl}, \mathrm{BUN} 68.4 \mathrm{mg} / \mathrm{dl}, \mathrm{Cr} 2.4 \mathrm{mg} / \mathrm{dl}, \mathrm{BS} 324 \mathrm{mg} / \mathrm{dl}$. 単純 X 線写真 では niveauを伴う拡張した小腸, 遊離ガス, 腹部 CT では腹腔内 遊離ガス, 腸管壁, 腸間膜内ガスを認めた. 消化管穿孔の診断で緊 急手術施行. 開腹すると小腸は著明に拡張し, 腸管壁, 腸間膜に気 腫を認めた. 麻瘏性イレウスによる腸管内圧上昇, 腸管粘膜損傷が 原因と判断. イレウスチューブを挿入し, 小腸内容を排除後, 留置 した. 術後経過良好で第 23 病日退院. [考察]本症は腸管壁内に多 数の囊腫様気腫を形成する比較的まれな疾患. 原因としては, 腸管 内圧上昇, 腸管虚血や炎症に伴うもの, 慢性肺疾患に伴うもの, 薬 剤性のものが挙げられる. 治療としては保存的療法が原則である が, 腸管虚血, 炎症によるものは緊急手術が必要となり, 原因疾患 の鑑別が重要. 本症例では, 炎症反応陽性, $\mathrm{Cr}$ 值の上昇, 向精神 薬内服中であって, コントロール不良の糖尿病を合併しており, 腹 部所見の信頼性が低いことを考慮し, 緊急手術を施行した.
PC-1-083 成人腸回転異常症により十二指腸狭窄をきた した 1 例

田中潤一郎, 志田晴彦, 大木亜津子, 東 久登, 坂佳奈子, 山形誠一, 増田幸蔵, 今成朋洋, 町田武久, 山本登司 （東京厚生年金病院外科）

症例, 65 歳男性. 50 歳ころより食事椇取量が少なくなっていた が, 2001 年 5 月頃からさらに減少し嘔吐するようになった. 8 月ま での 3 か月間に $7 \mathrm{~kg}$ の体重隇少. 現症は $162 \mathrm{~cm}, 48 \mathrm{~kg}$. 全身状態 良好.上腹部は蠕動を伴う拡張した腸管により膨隆していた.触診 すると液体貯留音が聴かれた。 上部消化管造影にて十二指腸の著 しい拡張と水平脚での通過障害を認めた. 腹部 CT, MRI, 超音波 検査では上腸間膜動脈と大動脈のなす角度は鋭角であった. 血液 検査所見では, 筫血・電解質異常・低栄養を認めなかった. 上腸間 膜動脈症候群あるいは腸回転異常症による十二指腸狭窄の診断で 9 月 19 日に開腹手術を施行した. 手術所見では Treitz 勒帯は存 在せず, 小腸は右下腹部から左腹部に向かって走行し, 回腸末端が 十二指腸の腹側を通過し癒着により十二指腸を締めつけていた。 $180^{\circ}$ の腸回転異常による十二指腸狭窄と診断した. 回腸の癒着 を剥離し小腸全体を $180^{\circ}$ 反時計方向に回転させ正常の位置に修 復した.さらにダブルトラクト十二指腸空腸吻合を行った.術後経 過は良好で術後 15 病日退院となった. 術後 5 か月で体重は $54 \mathrm{~kg}$ まで増加した．文献的考察を加えて報告する.

PC-1-084 von Recklinghausen 病に合併し, 多彩な組織 型を示した多発性十二指腸・小腸 GIST の 1 手術例 中島 健 ${ }^{11}$, 関屋 亮 ${ }^{1)}$, 宮崎哲真 ${ }^{1}$, 小谷幸生 ${ }^{1}$, 帖佐英一" ${ }^{1}$, 児玉英之 ${ }^{17}$, 中村都英"), 松崎泰憲 ${ }^{11}$, 鍋島一樹 ${ }^{2}$, 鬼塚敏男 ${ }^{1}$ (宮崎医科大学第二外科 ${ }^{1}$, 宮崎医科大学第二病理 ${ }^{2}$ )

von Recklinghausen 病（以下 $\mathrm{R}$ 病）は皮虐色素斑と多発 性神経線維腫を特徵とする常染色体優性遺伝疾患である. 今回我々は R 病に合併した Gastrointestinal stromal tumor(以下 GIST)の 1 手術例を経験した. 症例は 75 歳男性. 意識消失発作が出現し, 近医に緊急搬送され, 経過観察中に 下血を認めたため, 当院紹介入院となった. 緊急血管造影に て十二指腸と小腸に腫瘍濃染像を認めた. 腹部 CT 検査で は膀胱直上に径 $10 \mathrm{~cm}$ 大の腫瘤を認め, その他にも腹腔内 に数個の腫瘤を認めた. 小腸腫瘍からの出血と診断し手術 を施行した. 術後の病理組織学的検索では GIST (umcomitted type, neural differentiation, smooth muscle type) と 様々な組織型を呈していた， $\mathrm{R}$ 病に合併する消化管病変と しては非上皮性の腫瘍が知られている．GIST の概念の普 及に伴い R 病に合併した GIST の報告例が散見されるが 自験例のように同一症例で多彩な GIST の組織像を示した という報告はいまだ見ない，本症例および本邦報告例につ いて若干の文献的考察を加えて報告する. 
PC-1-085 右副腎転移を伴い急速に進展した小腸 malignant gastrointestinal stromal tumor $の 1$ 例 今井 寿" ${ }^{1}$, 足立 泰 ${ }^{1)}$, 佐治重豊 ${ }^{2}$

(足立病院外科 ${ }^{11}$, 岐阜大学第 2 外科 ${ }^{21}$ )

【症例】62歳の男性. 右肩痛を主訴に当院を受診した. CT, MRI 検査にて右副腎に直径約 $6 \mathrm{~cm}$ の腫瘍を認め, 右副腎腫瘍の診断 で他院へ転院となった. 内分泌学的異常は認めず, 腹腔鏡下生検 にて転移性副腎腫瘍と診断された。よって，原発巣の精査目的に 当院へ再入院となった. 再入院時, 腹部触診にて下腹部に可動性 が比較的良好な腫瘍を触知し, 腹部 CT 検査で同部に直径約 10 $\mathrm{cm}$ の腫瘍を認めた. 小腸肉腫の右副腎転移の診断で, 小腸部分切 除術と右副腎腫瘍をを肝右葉と右腎合併切除で摘出した. 小腸腫 瘍は粘膜面の潰瘍形成, 腫瘍内血腫, 多発性の小膿瘍を認め, 右 副腎は出血を伴う海綿状腫瘍であった。病理組織学的には好酸性 の胞体に富み, 異型の目立つ類上皮様の腫瘍細胞が浸潤性に増殖 していた. 核分裂像が著明で，10HPFに約 12 個の分裂像を認め た. 免疫組織学的検査では c-kit は陽性, SMA は一部陽性であり gastrointestinal stromal tumor と診断された。 術後経過は良好で あったが, 早期に再発, 胸腹水の出現を認め, 術後 34 日目に永眠 した.【結語】本症例は GIST としては極めて悪性度の高い症例で あったと考えられ，若干の文献的考察を加え報告する.

PC-1-086 䐙腫瘍との鑑別が困難であった十二指腸 GIST の一例

平本明徳, 成田 洋, 中村明茂, 加藤克己, 福井拓治, 中 村善則，植田拓也，松尾洋一，宇佐見詞津夫，佐野正明 (刈谷総合病院)

症例は 54 歳男性. 糖尿病と高血圧にて近医に通院中で あった. 健診時の腹部超音波検査にて, 荤臓に腫瘍像を指 摘された. 自覚症状は特に無く, 平成 13 年 8 月 16 日精査 目的で当院内科入院となった. 入院時血液生化学所見で は, 血糖值が 140 と軽度上昇を認める他, 特に異常は無 かった. 腹部 CT, MRI にて膵鈎部に $45 \times 36 \times 46 \mathrm{~mm}$ 大の 境界明瞭な腫瘤を認め, 十二指腸への圧排も疑われた. 莿 頭部腫瘍の診断にて平成 13 年 9 月 18 日，幽門輪温存䐙 頭十二指腸切除術を施行した。摘出標本では十二指腸下 行部に直径約 $4 \mathrm{~cm}$ 大の腫瘍を認め腪頭部側への発育が見 られた. 病理組織学的検查にて十二指腸笳層より発生し たGIST と判明し, 免疫組織学的検索では c-kit, CD34, $\alpha$ SMA が陽性であり, HHF35, s-100 が陰性であって uncomitted type と考えられた. 近年, 消化管 GIST の報告は 増えてきているが, 十二指腸原発のものは稀であり, 若干 の文献的考察を加えて報告する.
PC-1-087十二指腸乳頭部に発生した孤在性 PeutzJeghers 型 polyp の一例

蒲原行雄 ${ }^{1)}$, 川下雄丈 ${ }^{1)}$, 山田雅史 ${ }^{1}$, 岸川博紀 ${ }^{11}$, 関根一 郎 ${ }^{2)}$, 田島義証 ${ }^{3)}$, 兼松隆之 ${ }^{3)}$

(光晴会病院外科 ${ }^{1}$, 長崎大学原研病理 ${ }^{21}$, 長崎大学医学 部第二外科 ${ }^{3)}$ )

家族発生や皮膚症状を欠く孤在性の Peutz-Jeghers 型 polyp の報告は少なく，中でも十二指腸発生例は極めて稀である. 今 回, われわれは,十二指腸乳頭部に発生した 1 手術例を経験した ので文献的考察とともに報告する. 症例は 53 才男性. 心㸗部痛 の精査のため近医で上部消化管内視鏡検査を受け十二指腸乳頭 部の腫瘍を指摘され, 治療目的で当院紹介となった. 負血・黄㾝 なく腫瘍は約 $4 \mathrm{~cm}$ で亜有茎性, 乳頭部全体を占め, 生検では group 3 villous adenoma であった. 腫瘍による十二指腸および 乳頭の通過障害が腹痛の原因と診断し, 全胃幽門輪温存朠頭十 二指腸切除術を施行した. 術後,一時的に残存莿の膵炎を生じた が軽快退院し, 現在良好に経過している.摘出標本の病理学的検 索では粘膜筋板の増生を伴う過誤腫性 polyp で悪性化の所見は 認められず，家族発生や口唇の色素沈着は認めらないことから 弧在性の Peutz-Jehgers 型 polyp と診断した. 自験例を含む本 邦の報告では，十二指腸乳頭部発生例は 3 例と極めて稀であっ た. 悪性化の可能性が 5-10\% あるため, 乳頭部発生例では, 根 治性と手術侵襲軽隇の両立が治療上の重要な問題である.

PC-1-088 腹腔鏡下に整復した $\mathrm{S}$ 状結腸間膜内ヘルニア の 1 例

渡部通章 ${ }^{1)}$ ，三森教雄 ${ }^{1)}$ ，志田敦男 ${ }^{11}$ ，吉田達也 ${ }^{21}$ ，篠田知 太朗 ${ }^{2}$, 川野 勧 ${ }^{2}$, 栗原 健 ${ }^{2)}$, 羽田丈紀 ${ }^{2)}$, 山崎洋次 ${ }^{1)}$ (東京慈恵会医科大学外科 ${ }^{1}$, 神奈川県立厚木病院外 科 ${ }^{2)}$ )

【症例】68 歳男性. 下腹部痛，悪心，嘔吐を主訴に受診した. 腹部 単純 X 線検査で拡張した小腸を認め, 開腹歴のない初回腸閉塞の 診断で入院した. 腹部 CT では小腸の腸閉塞で原因は下腹部であ ることが推測された，絞抳性イレウスの徴候はずイレウス管を挿 入し保存的に経過観察ところ, 症状は改善した. 数日後にイレウス 管造影を施行したところ,左下腹部に閉塞部位が確認され,ここで イレウス管はとまっていた，注腸検査では大腸に異常所見は認め られず, CT では鼠径, 大腿, 閉鎖孔ヘルニアは否定されたため, 他の内ヘルニアが最も疑われた. 保存的な治療で腸閉塞は解除さ れないために, 待期的に腹腔鏡下イレウス解除術が施行された.手 術所見は, $\mathrm{S}$ 状結腸の腸間膜左葉に欠損部がありここより腸間膜 内に小腸が約 $10 \mathrm{~cm}$ 入り込んでいた. ヘルニア門を切開拡張し内 部の瘉着を剥離し, 嵌頓した小腸を整復した. 腸切は施行せず，へ ルニア門は縫合閉鎖した. 以上の操作はすべて腹腔鏡下で施行さ れた.【まとめ】S 状結腸間膜内ヘルニア (左葉欠損型) は稀な疾患 である.われわれはこの貴重な症例を経験したとともに腹腔鏡下 にヘルニア整復を経験したのでここに報告する。 


\section{PC-1-089 原発性十二指腸癌 5 切除例の検討}

木村俊久, 片山寛次, 村上 真, 廣野靖夫, 前田浩幸, 五 井孝憲, 飯田 敦, 竹内一雄, 廣瀬和郎, 山口明夫 (福井医科大学第一外科)

【対象】当科で経験した原発性十二指腸癌切除例 5 例を検 討した.【結果】(臨床像) 全例進行癌であった. 平均年齢は 61.8 才であった. 男性 2 例, 女性 3 例であった. 主訴は上 腹部痛が 2 例, 筫血が 2 例, 筫血が 1 例であった。病恼期 間は平均 5 か月であった. 病変の占拠部位は球部 2 例, 下 行部 1 例, 水平部 1 例, 上行部 1 例で, 十二指腸乳頭を境 にすると乳頭上部が 3 例, 乳頭下部が 2 例で差はなかっ た. (手術) 膵頭十二指腸切除 2 例, 幽門輪温存苏頭十二指 腸切除 1 例, 幽門側胃切除 1 例, 十二指腸部分切除 1 例で あった. (病理所見) 肉眼型では 2 型が 3 例と多かった. 組 織型では分化型腺癌が多かった。深達度は ss が 1 例, se が 3 例, si が 1 例であった.リンパ節転移は $\mathrm{n} 1$ が 1 例, $\mathrm{n} 4$ が 1 例であった.【まとめ】病悩期間が比較的長く, 進行 癌で発見される場合が多かった，上部消化管内視鏡によ る十二指腸下行部までの丹念な観察により早期発見する ことで, 予後の向上が期待できると思われた.

PC-1-090 当科における十二指腸乳頭部癌手術症例の検 討

福本晃久, 久永倫聖, 金廣裕道, 高 済峯, 長尾美津男, 池田直也, 鹿子木英毅, 秋元佳太郎, 小川護仁, 中島祥介 (奈良県立医科大学第 1 外科)

【目的】当科における十二指腸乳頭部癌手術症例の治療成績 と予後規定因子を検討した.【対象】1989 年〜2001 年に手術 した十二指腸乳頭部癌 19 例を対象とした. 生存曲線は Kaplan-Meier 法を, 有意差検定は log-rank 法を用いた. 【結 果了男性 9 例, 女性 10 例, 年令は $45 \sim 77$ 歳 (平均 60.5 歳). 荤頭十二指腸切除術が 13 例, 幽門輪温存䐯頭十二指腸切除 術が 6 例で stageI が 3 例, stageII が 6 例, stageIII が 8 例, stageIVa が 2 例であった. 5 年生存率は $66.5 \%$ で, 8 例が再 発, 5 例が再発死している. 再発部位は肝, リンパ節, 局所 であった. 性別, 年令, 術前 PTCD の有無, 肉眼型, $\mathrm{t}$ 因子, du 因子, panc 因子, n 因子, stage, 組織型別にそれぞれ 2 群に分けて単変量解析したところ, panc 因子のみで有意差 があり, panc2 以上の症例は有意に予後不良であった（p <0.01）, n 因子では有意差を認めなかった.【結語】十二指腸 乳頭部癌手術症例において panc2 以上は予後不良であり， 再発は肝・リンパ節に多く認めた。このような症例には集 学的治療が必要であり, 今後更なる検討を要する.
PC-1-091 リンパ節の skip 転移再発をきたした S 状結 腸 $\mathrm{mp}$ 癌の 1 例

豊田和広, 中塚博文, 小川尚之, 杉 桂二, 大城久司

（吳市医師会病院外科）

【はじめに】腹腔鏡補助下大腸切除後に skip 転移再発をきた した症例を経験した. 【症例】 62 歳, 女性. 平成 12 年 6 月血便 を主訴に精查したところ, S 状結腸に $3 \mathrm{~cm}$ 大の Ip 型ポリープ を認めた. 7 月 12 日 piece-meal polypectomy を施行した. 高 分化腺癌, sm，脈管侵襲陽性で，切除断端浸潤も疑われ，8 月 31 日腹腔鏡補助下 $S$ 状結腸切除術を行った.リンパ節は No. 241, 242 を郭清した. 最終診断は mp, ly1, v0, n0, stage Iであった. 以後外来通院していたが, 翌年 2 月 CEA 值が 5.4 $\mathrm{ng} / \mathrm{ml}$ に上昇した. 再発部位ははっきりせず CEA, CT 等にて 慎重に経過観察した．その後 CEA は $10 \mathrm{ng} / \mathrm{ml}$ まで徐々に上 昇し, CT では No. 252 のリンパ節が増大傾向にあるため, こ の部への再発と判断した. 9 月 10 日 S 状結腸直腸前方切除 術, リンパ節郭清を行った. No. 252, 253へ腺癌の転移を認め た.【結語】腹腔鏡下大腸切除術は徐々に適応を広げられつつ あるが，リンパ節転移の診断は未だ難しく skip 転移も約 10 \%あるとされる．慎重に適応を選び，迅速病理診断の利用や sentinel node navigation surgery の応用も必要と思われる.

PC-1-092 CT による直腸癌進行度診断の正診率に関わ る因子の解析

野村昌哉, 宗田滋夫, 根津理一郎, 吉川幸伸, 松田 宙, 文元雄一

（日生病院外科）

【目的】直腸癌の術前病期診断におけるCT の正診率に関 わる因子ついて検討した.【方法】対象は造影 CT で術前評 価し得た直腸癌切除例 73 例で, 術後組織所見と比較し, 壁深達度とリンパ節転移における正診率に関わる因子を 検討した.【成績】 (1)壁深達度に対する正診率は $71.2 \%$ (52 例 $/ 73$ 例)，過大評価率が $27.4 \%$ (20 例 $/ 73$ 例)，過小評価 率が $1.4 \%$ （1 例 $/ 73$ 例） であった. (2) 過大評価群の腫瘍 最大径 (平均 $7.1 \mathrm{~cm}$ ), 術前 $\mathrm{CRP}$ 值 (平均 $1.1 \mathrm{mg} / \mathrm{dl}$ ), 術 前 fibrinogen 值（平均 $453 \mathrm{mg} / \mathrm{dl}$ ） は，正診群（それぞれ 平均 $4.8 \mathrm{~cm}, 0.2 \mathrm{mg} / \mathrm{dl}, 387 \mathrm{mg} / \mathrm{dl}$ ) に比し有意に高値を示 した $(\mathrm{p}<0.05)$. (3) 傍直腸リンパ節転移に対する正診率は $64.4 \%$ (47 例 $/ 73$ 例) で, 偽陽性率は $9.6 \%$, 偽陰性率は 26.0 $\%$, sensitivityは $76.7 \%$, specificity は $55.8 \%$ であった. 【結論】術前 CT による直腸癌壁深達度評価において, 腫 瘍径の大きいものや術前 acute phase protein (CRP, fibrinogen)值が高値を呈する症例では，深達度を過大評価 する可能性があり注意すべきと考えられた。 
PC-1-093 鼠径リンパ節転移を伴った直腸 sm 腺内分泌 細胞癌の 1 例

西村 淳, 武者信行, 斉藤有子, 坂田英子, 高野征雄

(秋田赤十字病院外科)

【症例】 72 歳, 女性. (主訴】左鼠径部腫痹. [現病歴】左鼠径部腫痹を自覚し, 次第に大きくなったため受診。

【身体所見】左鼠径部に直径 $3.5 \times 2.9 \mathrm{~cm}$ の腄痹. 同腄裙の穿刺吸引練胞診は classI. 直腸診にて歯状線より $1.5 \mathrm{~cm}$ 口側に, 直径約 $1 \mathrm{~cm}$ の可動性良好な隆起

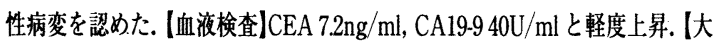
腸内視镜] 直腸 $[\mathrm{Rb}]$ に直径䄪 $1 \mathrm{~cm}$ の隆起性病変を認为, 生検に一低分化型

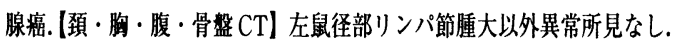

以上より，直腸癌 $[\mathrm{Rb}] \mathrm{SM}, \mathrm{N} 4(+), \mathrm{H} 0, \mathrm{PO}, \mathrm{M}(-)$ ：stage IV の術前 診断で, 2001 年 11 月 14 日経肛門的腫場切除, 左鼠径部腫痹切除を施行. 【病理所見】 sm, lyl $/ 2$ ?, v0, ow (-), aw (-), ew (-). HE 染色で, 直 腸腫場は低分化型腺癌を䇟うが，一部神経内分泌への分化の可能性も疑われ

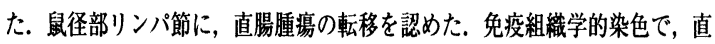
腸腫場，リンハ節転移巣とも，低分化型腺癌の一部に neuroendocrineへの分 化を伴う腺内分浽練胞癌と考元られた。

【術後経過】術後補助化学潦法として, FLP3 コース施行. 現在転移, 再発無 L.

【結語】まれな直腸原発の腺内分汹緗胞癌の1例を経験した。

PC-1-094 経肛門腹式直腸切除・経肛門結腸肛門吻合術 を施行した下部直腸 GIST の 1 例

矢野達哉1), 小野仁志 ${ }^{1)}$, 佐藤元通 ${ }^{2}$, 渡部祐司 ${ }^{3)}$, 河内寛 治 ${ }^{3)}$

(西条中央病院外科 ${ }^{1)}$ ，町立吉田病院外科 ${ }^{2)}$ ，愛媛大学医 学部第 2 外科 ${ }^{3}$ )

【症例】患者はは 69 歳の女性, 下血を主訴に来院, 大腸ファー バーにて肛門輪から約 $2 \mathrm{~cm}$ の部位に径 $4 \mathrm{~cm}$ の弾性硬で可動 性良好の粘膜下腫緜が認められた。 経肛門的針生検を行い, 免 疫組織染色にて下部直腸原発 GIST (uncommited type) と診 断した. MRIでは子宮・胵壁への浸潤は否定的であり, 経肛 門腹式直腸切除・経肛門結腸肛門吻合術を行った. 【考察】直 腸原発 GIST は，現在までに本邦では検索範囲内では 8 例し か報告されていない稀な疾患である。術前に確定診断された 例は内視鏡的腫瘍部分切除を行って診断した 1 例のみである が, 我々が行った経肛門的針生検は免疫組織学的検討を行う ために必要な十分な量の練胞を採取することが安全にできる ため, 非常に有用な方法である. 通常の器械吻合も不可能なよ うな下部直腸原発のものに対しては全例, 直腸切断術が行わ れているようだが, 術前に確定診断を行い, MRI 等にて他臓 器浸潤がない症例に対してはQOLを考慮した術式も可能で あると考える.【結語】下部直腸原発 GIST に対し, 術前に確定 診断を行い, 経肛門結腸肛門吻合術を行った症例を報告した。
PC-1-095 大腸癌卵单転移症例の臨床病理学的検討

宮川公治

(京都府立医科大学消化器外科)

【目的】当科における大腸癌卵巣転移症例の臨床病理学的特 性と外科治療の意義について検討した.【方法】 1990～2001 年までで当科において切除された女性大腸癌症例 617 例中 の卵巣転移症例 9 例について検討した.【結果】卵巣転移初 発症状は, 疼痛 $(67 \%)$, 下腹部腫瘤 $(50 \%)$, 性器出血 $(33$ $\%)$ ，尿路系出血 (17\%) であった。中分化型腺癌 $(66 \%)$ が 最多であった．閉経との関連は認められなかった. CEA の上昇は認められずCA125 と SLXの上昇を認めた．腹膜 播種性転移,リンパ節転移との相関は明らかでなかった.エ ストロゲンレセプターとコアクチベーターの高発現を認め た. 現在術後 96 ケ月で(再発)生存中の 1 例を認めている. 他は早期に再発死亡した. 34 歳の若年例では術後 3 ヶ月で 急速な再発を認めた.【考察】ホルモンレセプターとそのコ アクチベーターの関与の可能性が示唆された. 単独卵巣再 発例に限っては外科的切除が予後を改善しうる可能性があ ると考えられた．若年女性大腸癌症例は卵巣転移の可能性 を考えて骨盤 CT 等での経過観察を要すると考えられた.

PC-1-096 当科における大腸癌卵巣転移症例の臨床病理 学的検討

長谷川潤, 瀧井康公, 藪崎 裕, 土屋嘉昭, 梨本 篤, 田 中乙雄

(県立がんセンター新潟病院外科)

【目的】当科における大腸癌の卵巣転移症例について臨床病 理学的特徴を明らかにする. [症例】 1990 年 1 月から 2001 年 12 月までの 12 年間で当科における女性大腸癌症例 613 例のうち大腸癌卵巣転移切除例 6 例 $(0.98 \%)$.【結果】卵巣 切除時年齢 43 歳 79 歳. 閉経前症例 2 例, 閉経後症例 4 例. 同時性 2 例, 異時性 4 例. 原発巣の占拠部位は $\mathrm{C} 1$ 例, $\mathrm{CV} 1$ 例, $\mathrm{A} 1$ 例, $\mathrm{S} 2$ 例, Rs1 例. 肉眼型はいずれも 2 型. 組 織学的病期は stageIIIa 1 例, stageIV 5 例, 5 例に腹膜播種 が見られた。原発巣組織型は wel 2 例, $\bmod 3$ 例(うち 1 例 は muc 成分を含む), muc 1 例. 転移巣組織型は wel 2 例, $\bmod 2$ 例, $\operatorname{muc} 2$ 例. 原発巣手術の根治度は A 1 例, B 3 例, C 2 例. 異時性症例は原発巣手術から卵巣切除術までの 期間は 9 か月, 12 か月, 15 か月, 21 か月で, 卵巣切除理由 は CurB が期待された症例が 2 例, Subileus 解除目的が 2 例. 片側卵巣転移例において, 対側卵巣転移が同時性, また は, 異時性に見られた. ER, PgR は原発巣, 転移巣ともに 陰性であった。同時性卵巣転移例に長期生存例が見られた。 
PC-1-097 大腸癌術後肺転移手術症例の検討

黄 泰平 ${ }^{11}$, 山崎芳郎 ${ }^{1}$, 弓場健義 ${ }^{11}$, 福井雄一 ${ }^{11}$, 籾山卓哉1), 武田浩二1)，廣田昌紀 ${ }^{1)}$, 芝 英一" ${ }^{12}$, 中山貴寛 ${ }^{11}$, 小林 晏 ${ }^{2}$ (大阪厚生年金病院外科 ${ }^{1}$, 大阪厚生年金病院病理部 ${ }^{21}$ )

【目的と対象】大腸癌術後の肺転移に対する手術適応を, A：単 発例, B：片側多発でも個数が少なく完全切除が可能と考えら れる症例, C：両側例でも病変の大きい方の手術を先行し, 経過 観察の後，対側を後日手術する方針で取り組んできた. 1992 年 1 月から 2001 年 12 月までの肺転移手術症例 10 例を対象に 検討した.【結果】A 群 7 例中現在生存例は 2 例であった. 1 例は 1988 年 1 月に腸切除術施行. 1989 年 2 月に肝転移で肝切除術施 行. 1992 年 3 月肺転移にて肺部切施行し生存中. 他 1 例は 2000 年 3 月に肺部切施行. 組織学的断端陽性で，肺の局所再発にて 2001 年 3 月肺葉切除施行し生存中. 再発死亡例中長期生存例を 1 例認めた. 腸切除術術後 2 年 5 力月後に肺転移で肺部切施行. その後同側の肺転移再発で 2 度の切除術施行し, 初回肺術後 7 年 11 力月目に癌死した. B 群の 1 例は肺術後 3 年 3 力月で多発 肺転移で癌死した．C群の 2 例は他の転移発生のため片側肺手 術後対側肺の手術適応がなくなった.【まとめ】1, B 群, C 群の予 後は不良であった. $2, \mathrm{~A}$ 群で長期生存例を認めた. 3 , 肺部分切 除に際しては組織学的断端を陰性にすることが肝要である.

PC-1-098 大腸癌肺転移に対して抗癌剂抵抗性となった 後でも気管支動注化学療法が有効であった 2 例

鍛 利幸，三木 明，岡本大輔，古家敬三，井ノ本环也， 亥埜恵一, 東山 洋, 有本 明, 中島康夫, 浮草 実 (大阪赤十字病院外科)

大腸癌肺転移に対して全身化学療法抵抗性となうた後でも 気管支動注化学療法が臨床的に有効であった 2 例を報告す る. 症例 $1: 60$ 才, 女性. $\mathrm{S}$ 状結腸癌, 両側多発性肺転移症例. 平成 10 年 2 月, $\mathrm{S}$ 状結腸切除後, 5-FU, CPT-11 + CDDP, CPT$11+5-\mathrm{FU} / \mathrm{LV}$ と変更し各々 $\mathrm{PR}$, long NCを得たが, 肺門部転 移巣が徐々に増大, 平成 12 年 12 月, 突然無気肺を来たして呼 吸不全となった。全身化学療法を諦め, 気管支動脈から, CDDP50mg, 5FU500mg, MMC4mg を動注した. 肺門部転移 单は縮小し, 無気肺は軽快した。症例 $2: 70$ 才, 男性. 平成 9 年 2 月, 直腸切断術施行後, 骨盤, 肺再発に対して各々切除 を行ったが, 平成 11 年 8 月, 肺に再々発した. $5 \mathrm{FU}, \mathrm{CPT}$ $11+\mathrm{CDDP}, \mathrm{CPT}-11+5 \mathrm{FU} / \mathrm{LV}$ と化学療法を行うも, 徐々に 抗癌剂抵抗性となり，血痰，胸部痛が増悪してきた。平成 13 年 8 月，上述の気管支動注化学療法を行ったところ血痰は消 失した. 結語：大腸癌肺転移症例において, 喀血や無気肺など 生命に関わる症状がある場合, 全身化学療法抵抗性でも気管 支動注化学療法は治療選択肢のひとつになりうる.

\section{PC-1-099 成人腸重皘 5 例の検討}

白子隆志, 横尾直樹, 北角泰人, 足立尊仁, 吉田隆浩, 浦 克明，田中善宏，濱洲晋哉，長田博光

(高山赤十字病院外科)

[目的・対象 $] 1990$ 年 7 月から 2002 年 2 月までに経験した, 成 人腸重積症 5 例の臨床病理学的特徴について検討を加えた. [結果]期間中の小児腸重積手術症例は 14 例で, 成人腸重積は 5 例， $26 \%$ であった. 性別は，男性 2 例，女性 3 例. 年齢は平 均 $66.4(25 \sim 86)$ 歳. 症状は, 腹痛 2 例, 嘔吐 1 例, 両者 2 例, 腫瘤触知 1 例. 発生部位は, 小腸型 2 例, 回盲部型 3 例であっ た. 原因疾患は腫瘍性 4 例，非腫瘍性 1 例で, Peutz-Jeghers (PJ) ポリープ (癌) 1 例, 盲腸癌 1 例, 盲腸絨毛腫瘍 1 例, 虫 垂囊胞腺腫 1 例，炎症性 1 例で，悪性腫瘍は $50 \%$ を占めた. 腫瘍形態は, いずれも隆起型で比較的柔らかく, 平均最大腫瘍 径は, $5.5 \mathrm{~cm}(40$ ～ $70 \mathrm{~mm})$ であった. 腹部超音波・腹部 CT にて 5 例中 4 例に術前診断された. 腸管切除が全例に施行さ れ, PJ 症例には, 二期的開腹下術中内視鏡的ポリープ切除術を 施行した. [考察]成人腸重積症は小览と比較して稀な疾患で, 悪性腫瘍によるものが多い. 腹部超音波・CT 等の画像診断で 術前診断は可能である. 成人での腹痛・腸閉塞症状時には, 腸 重皘も念頭に置き, 迅速な診断・観血的治療が必要である.

PC-1-100 酎術不能消化器癌患者に対する活性炭吸着抗 癌剂局所注入療法

藤山准真, 阪倉長平，高木 剛，伊藤忠雄，大辻英吾，北 村和也，系井啓純，園山輝久，萩原明於，山岸久一 (京都府立医科大学消化器外科)

【はじめに】耐術不能な食道癌 7 例，胃癌 5 例，直腸癌 2 例 に対し活性炭吸着抗癌剂の内視鏡下局所注入療法を行い 有効な結果を得たので報告する.【対象と方法】食道癌 7 名, 胃癌 5 名, 直腸癌 2 名の計 14 例を対象とした. 食道癌 6 例に PEP-CH (PEP として 40〜100mg)，1 例にMTX$\mathrm{CH}$ (MTX 500mg) を，胃癌 5 例に MTX-CH（MTX 250 ～500mg）を，直腸癌 2 例に MTX-CH（MTX 100〜400 $\mathrm{mg}), \mathrm{MMC}-\mathrm{CH}(\mathrm{MMC}$ 8 32mg) を，腫瘍内に内視鏡的 に局所注入した. 効果判定は内視鏡および透視検查にて 行った.【結果】食道癌と胃癌症例は全例 CR を示し, 原癌 死はない. 2 例は再発したが再治療により癌は消失した. 7 例は腫瘍消退後 12～64 ケ月再発を認めず. 直腸癌症例 では, 24 ケ月後と 6 ケ月後に他病死するまで 2 例共腫瘍 の著しい縮小を認めた. 各治療を通して顕著な副作用は認 めなかった.【考察】活性炭吸着抗癌剂の局所注入療法は, 本症例のような耐術不能癌患者にも低侵襲であり病巣局 所のコントロールについては有効な治療法と考えられる。 
PC-1-101 14 歳女览盲腸癌の 1 例

青竹利治, 横町 順, 松村光誉司, 打波 大, 堀内哲也

(福井医科大学医学部医学科第二外科)

大腸癌が 15 歳以下の小児に発生することは非常に稀である.今 回我々は 14 歳女览の盲腸癌の 1 例を経験したので報告する. 症例 は 14 歳女児. 12 歳より貧血あり. 家族歴は父方の祖父に胃癌, 食 道癌, 母方の祖父に胆管癌がある. 平成 13 年 3 月末より腹痛を認 め増悪し 5 月 30 日に近医を受診した. 大腸内視鏡検查および注腸 検査で回盲弁に Borrmann2 型の盲腸癌が疑われ当科紹介となっ た. 生検の結果は adenocarcinoma であった. 来院時全身状態は良 好であったが, 体重隇少と右下腹部に $4 \mathrm{~cm}$ 大の圧痛を伴う腫瘤を 触知した. 6 月 12 日右半結腸切除術, D3 郭清を施行した. 病理診 断は wel >mod, si, lyl, v1, ow (-), aw (-), ew $(-), \mathrm{n}(-)$ stageIIII であった. 術後は経過良好で 7 月 17 日より UFTE 顆粒 $2.25 \mathrm{~g}$ ，PSK3g の投与を開始し退院した。平成 14 年 2 月 4 日現在 CA19-9 が 40 とわずかな上昇を認めるのみで再発の徴候は認めら れない. 小児は成人に比べ初期段階で腹痛以外の自覚症状に気づ くことが少なく進行例が多い．また組織学的にも悪性度の高い粘 液癌や印環細胞癌が多く早期発見が重要である. 小児であっても 積極的に大腸内視鏡検査および注腸検査が必要である。

\section{PC-1-102 原発性虫垂癌の臨床病理学的検討}

宇高徹総, 徳毛誠樹, 山本寛斉, 高尾智也, 曽我部長徳, 前田宏也, 水田 稳, 白川和豊, 大屋 崇 (三豊総合病院外科)

(目的，対象) 1990 年から 2001 年までの 12 年間に当院で経験した大 腸癌手術症例 648 例のうち虫垂癌 10 例 $(1.5 \%)$ を臨床病理学的に検 討した. (結果) 男性 5 例，女性 5 例で，年齢は 56-94 歳（平均 75.1 歳)であった. 主訴は右下腹部痛 4 例, 腫瘤触知 3 例, 負血 2 例, 無 主訴 1 例であった. 術前診断は盲腸癌 3 例, 急性虫垂炎 3 例, 虫垂腫 瘍 (虫垂癌の疑い) 2 例で虫垂癌と病理組織学的に確定診断できたの は 1 例のみであった. 腹部 CT が施行された 7 例中 6 例 $(86 \%)$ に虫 垂あるいは盲腸に腫瘤が認められ，注腸・大腸内視鏡で虫垂癌・盲 腸癌が疑われた. 術式は右半結腸切除 4 例, 回盲部切除 4 例, 盲腸部 分切除 1 例, 虫垂切除 1 例であった. 予後は II 期の 2 例, IIIa 期の 2 例は生存中であるが, IIIa 期の 1 例は肺転移・腹壁浸潤で, IIIb 期の 1 例は腹膜転移で死亡した. IV 期の 1 例は担癌生存中である が, 1 例は肝転移で死亡した. 病期不明の 1 例は虫垂切除後に断端再 発で死亡, 1 例は他病死した. (結語) 原発性虫垂癌は術前病理学的に 診断ができたのは 1 例のみであったが, CT で $86 \%$ の症例に局在診 断ができ, 注腸・大腸内視鏡で虫垂癌・盲腸癌が疑われた. 全例が進 行癌で, III a 期以上および虫垂切除のみ症例は予後不良であった.
PC-1-103 70 年前および 30 年前に報告された家族性大 腸腺腫症の一家系 岩間毅夫, 星野直明, 岩崎 晃, 家城和男, 松崎 淳

（佐々木研究所附属杏雲堂病院外科）

目的： 70 年前および 30 年前に報告された家族性大腸腺腫症 (FAP) 家系の患者を診療して考虑すべき示唆を得たので報告 する. 症例：症例 1 ; 33 歳男. 下行結腸癌の穿孔にて死亡. 剖 検でFAP と診断された(治療および処方 1933). 症例 2 ; 症例 1 の甥 37 歳, 非密生型 FAP の診断で回腸直腸吻合術を受け, 7 年後直腸癌が発生した. 症例 3 ; 症例 2 の娘 52 歳, 22 歳時 に父親と同時期に回腸直腸吻合術を受けた(臨床外科 1973). 30 年後 $(2001 / 2)$ 腔浸潤, リンパ節転移, 脳転移を伴う直腸 進行癌が発生した. 症例 4 ; 症例 3 の息子 24 歳, リンパ節転 移を伴う直腸癌にて大腸全摘回腸㾇造設術受けた $(2000 / 12)$. 症例 5 ; 症例 4 の妹, 19 歳, 大腸癌無く回腸肛門管吻合術を受 けた $(2001 / 8)$. 症例 6 ; 症例 1 の孫 28 歳男, 回腸肛門吻合術 を受け 33 年後健在. 考察と結論：この家系のその他の症例を 合わせ, 直腸温存術式は 3 例に行われ 3 例ともに進行癌が発 生した. 大腸全摘術は 4 例（30 年以上経過 2 例）であり死亡 はない. 30 年 (20 歳代- - >50 歳代) という長期で見ると, 直 腸温存術は予後に関係するような直腸癌発生の危険が高い.

PC-1-104 大腸癌とカルチノイドを合併した潰痬性大腸 炎の一例

青木成史, 渡邊昌彦, 長谷川博俊, 馬場秀雄, 山本健太郎, 吉馿健太郎，似鳥修弘，矢部信成，柳 在勳，北島政樹 (慶應義塾大学外科)

症例は 42 歳, 女性. 1987 年より全大腸炎型潰瘍性大腸 炎 (以下 UC) の診断にて加療中. 2001 年 3 月大腸内視鏡 検查にて直腸 $(\mathrm{Ra})$ に隆起性病変を認め, 生検で高分化型 腺癌と診断された. UC は緩解期であった. 同年 5 月腹腔 鏡併用大腸全摘術, 回腸囊肛門管吻合術, 回腸瘦造設術を 施行した. 大腸癌の手術診断は IIa + IIc, $1.0 \times 2.5 \mathrm{~cm}, \mathrm{SM}$, $\mathrm{P} 0, \mathrm{H} 0, \mathrm{~N}($ ( ) であった。病理組織学的には，炎症細胞浸 潤を伴う異形成組織中に高分化型腺癌 (ss, ly $1, \mathrm{v} 0$, INF$\beta, \mathrm{n}($ ( ))を認めた. また大腸癌より肛門側直腸の粘膜下 層に多発性の小腫瘤を認め, 病理組織学的にカルチノイ ドと診断した. Chromogranin 染色, synaptophysin 染色 いずれも陽性であった，術後 9 か月経過して大腸癌およ びカルチノイドの再発は認めていない，潰瘍性大腸炎に 大腸癌とカルチノイドを合併した例は非常に稀であり， これまで 3 例の報告があるにすぎない，若干の文献的考 察を加えて報告する. 
PC-1-105 顆粒球吸着療法により安全に手術できたステ ロイド抵抗性難治性潰瘍性大腸炎の 1 例 山本真人"，加藤博之"，吉松和彦和彦"，石橋敬一郎"，岩崎 清”， 山田理恵子"，久原浩太郎"，芳賀駿介"，小川健治"，佐中 孜 ${ }^{21}$ (東京女子医科大学附属第二病院外科"), 東京女子医科大 学附属第二病院内科 $\left.{ }^{2}\right)$

ステロイドを長期間大量投与された難治性潰瘍性大腸炎に対 し顆粒球吸着療法施行後安全に手術を施行できた症例を経験し たので報告する. 症例は 77 歳, 女性. 腹痛, 水様粘血下痢便を 認为近医受診, 潰瑒性大腸炎 (全大腸炎型, 活動期) の診断でス テロイド長期大量投与されたが, 症状の軽快なく手術目的にて 当院転院となった．前医でプレドニン $80 \mathrm{mg} / \mathrm{day}$ 使用していた ため, ステロイド漸隇目的で顆粒球吸着療法 (GCAP) を開始し た. 本治療開始值後より腹痛, 粘血便は消失した. その後ステロ

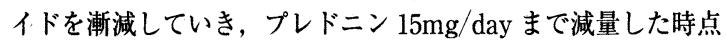
で, 大腸全摘術及び回腸瘦造設術を施行した. 尚, 手術前のステ ロイド総投与量は, プレドニゾロン換算で約 $10 \mathrm{~g}$ であり, 術前 1 ケ月の投与量は $710 \mathrm{mg}$ であった. また GCAP は計 5 回施行し た.切除標本は活動性潰瑒性大腸炎, 全大腸炎型であった. 術後, ステロイドの副作用である副腎不全, 感染症を含む合併症を生 じることなく順調に回復し術後 34 病日退院となった. ステロイ ド抵抗性潰瘍性大腸炎における顆粒球吸着療法は手術治療前の ステロイド淵減に効果的であったと考えられた。

\section{PC-1-106 直腸内分泌細胞癌の 1 例}

山内希美 ${ }^{12}$, 宮田知幸 ${ }^{12}$, 岡田将直 ${ }^{11}$, 外山真弘 ${ }^{12}$, 河合寿 -1), 加藤正夫" ${ }^{1}$, 宮下剛彦 ${ }^{21}$

(岐阜県立下呂温泉病院外科"), 岐阜県立下呂温泉病院病 理診断部')

【はじめに】内分泌細胞癌は臨床病理学的にも不明な点が多く予 後不良である.われわれは直晹内分泌細胞癌の1 例を経験した。 直腸内分泌細胞癌の本邦報告例は自験例を含め 33 例であった。 【症例】 78 歳, 男性. 平成 13 年 5 月 5 日加全身倦总感, 食欲 不振が出現し下血を認めたため当院内科を受診した：カルチノ イド症状は認めなかった。大腸内視鏡検查で下部直腸に Borrmanl 型腫場を認め, 生検で低分化型腺癌もしくは未分化 癌と診断された.腹部 CT 検査で肝転移を認めた. 腹会陰式直腸 切断術とリザーバー留置術を行った。免疫組織染色のクロモグ ラニン A, NSE で陽性像を示し, 内分泌細胞癌と診断された。 化学療法を開始したが, 平成 14 年 1 月 5 日死亡した. [考察]内 分泌細胞癌は予後不良であり, 低分化腺癌や未分化癌との鑑別 が困難である. 直腸内分泌細胞癌の本邦報告例は自験例を加え て 33 例であり, 術前から肝転移を認めた症例は 21 例であった。 早期癌の症例は 5 例あるが, 壁深達度と予後の関連はないと考 えられた【まとめ】内分泌細胞癌は外科的切除が第一選択と考 えられるが, 予後は不良で何らかの補助療法が必要である.
PC-1-107 直腸原発 cloacogenic carcinoma $の 1$ 切除例

上田貴威, 坂本和彦, 御江慎一郎, 中島公洋, 蓮田慶太郎, 穴井秀明

(国立大分病院)

今回, 我々は世界でも数十例の報告しかない直晹原発 cloacogenic carcinoma の 1 切除例を経験した. 症例は, 51 歳, 男 性. 主訴は, 肛門痛. 直腸診にて肛門直上後壁に弾性硬の腫瘤 を触知した. 入院精查にて, 4 群リンパ節転移を伴う Stage IV 直腸癌と診断. 主病巣切除目的に腹会陰式直腸切断術を施行 した. 病理組織所見では, H-E 染色にて粘膜下組織から筋層に かけて, 小型で N/C 比の大きな腫場練胞の浸潤・增殖を認 め, また免疫染色にて CEA 陽性, シナプトフィジン・クロモ グラニン A 陽性であり, cloacogenic carcinoma と診断され た. その後, 化学療法・放射線療法を施行したが, 術後 4 ケ月 目に癌死した. 本疾患は肧子期の排泄腔膜の遺残が発生母地 と考えられ, 肛門直腸悪性腫場の $2 \sim 3 \%$, 肛門管癌の $20 \sim 40$ \%を占めるとされる. しかし, 直腸原発は非常に稀であり, 比 較的予後良好な肛門原発のものとは異なり予後不良とされ る. 本症例も, 種々の集学的治療にもかかわらず急速な転㷌を とっており,この点も本疾患の特徽であると考えられた. 非常 に貴重な症例と考え, 若干の文献的考察を加えて報告する.

PC-1-108 術前放射線治療が有効であった骨盤内巨大肉 腫の 1 手術例

堀江久永 ${ }^{11}$, 岡田真樹 ${ }^{11}$, 佐藤政広 ${ }^{11}$, 宇井 崇1), 紫藤和 久 ${ }^{12}$, 永井秀雄" , 村石 修2，宇田宏一 ${ }^{31}$

(自治医科大学消化器一般外科 ${ }^{1)}$, 自治医科大学泌尿器 科 ${ }^{21}$, 自治医科大学形成外科 ${ }^{31}$ )

【はじめに】術前放射線治療により腫瘍を縮小させ, 根治手術 を施行できた骨盤内巨大肉腫の 1 例を経験したので報告す る. 【症例】 31 才男性. 2001 年 9 月肛門部痛にて発症した. 大 腸内視鏡検查では歯状線から口側 $10 \mathrm{~cm}$ まで直腸右前壁中 心の粘膜下腫場を認めた。 CT, MRIでは精襄より尾側に小 骨盤腔全体を占める $10.8 \times 7.3 \mathrm{~cm}$ の内部不均一な腫湟を認 め, 前立腺および直腸との境界は不明暸であった。経肛門的 生検では, 核異型の目立つ Spindle cell sarcoma で, 由来荿器 は不明であった。免疫染色で MIB1 陽性率が $50 \%$ 以上と高 值であったため, total $49 \mathrm{~Gy}$ の術前放射線治療を施行したと ころ, 腫瘍は $8.6 \times 6.8 \mathrm{~cm}$ に縮小したため, 骨盤内臓全摘, 禁 制代用膀胱作成, 後大腿皮弁による骨盤内充填術を施行し た. 病理所見は, 前立腺由来の Rhabdomyosarcoma で直腸 の粘膜下層まで浸潤していた. 膀胱側断端，尿道側断端およ び剥離面断端には腫瘍を認めなかった. [考察】通常, 肉腫に は放射線治療は有効でないとされるが, 本症例のように巨大 で增殖傾向の盛んな症例には, 有効な方法と考えられた. 
PC-1-109 繰り返す腸重積後に自然脱落した盲腸脂肪腫 の 1 例

高橋直樹, 南 智仁, 由里樹生, 高見 実, 大島 哲, 松 本 潤, 高西喜重郎

(東京都立府中病院外科)

大腸粘膜下腫瘍が腸重積を繰り返すうちに自然脱落する希な症 例を経験した. 症例は 55 才の男性で 1 年前から時々腹痛が出現し たが1日で改善していた，11月25日から同様の腹痛が出現し今回 は改善しないため近医で 12 月 1 日注腸検査を受けたところ下行結 腸に蟹の爪様所見を認め, 容易に整復されたものの整復後盲腸に基 部を有する $10 \times 5 \mathrm{~cm}$ 大のこん棒状腫瘍が明らかとなり, 盲腸原発 の粘膜下腫瘍による腸重積と診断された. その後紹介され精査中の 12 月 11 日に肍門に栓をされた感じがすると訴え, 直腸指診にて腫 瘤を触知し，CT 上重積せずに直腸内に存在する腫瘤が確認され た. 内視鏡的な摘出が困難なため同日入院し腰椎麻酔下に摘出した ところ $8 \times 4 \mathrm{~cm}$ 大の脂肪腫であることが確認された，12月13 日大 腸内視鏡検查を施行したところ，盲腸に頂上に潰瘍を伴う太い茎を 認め粘膜下腫瘍が脱落した後にいまだ浮腫を伴っている状態を観 察していると考えた. 腹痛, 貧血の進行等を認めないため 12 月 19 日退院となった. その後 2002 年 1 月 24 日大腸内視鏡検査を再検し たところ軽い隆起は残すもののほぼ多集中像を残すのみとなっ ており，遺残はないと考えられた．その機序も興味深く報告する.

PC-1-110 門脈圧元進症および多発性肝結節をきたした 直腸動静脈奇形の一手術例

暒原正俊, 岡田憲幸, 和田道彦, 正井良和, 宮原勅治, 橋 本 隆, 今井史郎, 柳橋 健, 小西 豊, 暒原建熙 （神戸市立中央市民病院外科）

症例は 78 歳男性. 既往歴は狭心症, 高脂血症. アルコー ル多飲歴なし, 肝炎ウイルスマーカー陰性. 腹部膨満感を 主訴に近医受診し，食道静脈瘤および多量の腹水を指摘 され当院紹介となった. 腹部 CTにて腹水に加え, 多発性 肝結節および直腸周囲に異常血管の集簇像を認めた。 MRA および血管造影検查にて, 上直腸動脈を流入動脈, 高度に拡張した辺縁静脈を流出静脈とする直腸周囲の巨 大動静脈奇形が描出され, 前述の異常血管の集簇部位と 一致した. また, 肝臓の多発性肝結節は門脈血流優位であ り, 原発性・転移性肝癌はいずれも否定的であった. 以上 の結果より直腸動静脈奇形が門脈圧の艺進をひきおこ し, 肝内に結節性病変をもたらしたと考えた. 食道静脈瘤 からの出血も認められたため, 硬化療法施行後, 待機的に 直腸前方切除術を行った. 病理組織標本にて動静脈奇形 に特徴的な拡張した小動静脈の移行像も確認された。術 後, 食道静脈瘤は縮小し, 腹水に加え肝内結節も消失し た.この稀有な症例に対して文献的考察を加え報告する.
PC-1-111 術前画像診断にて診断し得た遺残虫垂炎の 1 例

相沢俊二 ${ }^{11}$ ，西村顕正 ${ }^{11}$ ，萩原主税 ${ }^{1}$ ，柴崎 至 ${ }^{11}$ ，橋爪

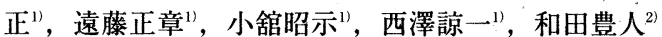
(青森市民病院外科 ${ }^{1)}$, 青森市民病院第 3 内科 ${ }^{2}$ )

(目的)今回我々は, 腹部超音波検査および大腸内視鏡検査にて術前 診断し得た遺残虫垂炎の 1 例を経験したので報告する. (症例) 53 歳女性, 10 歳時に急性虫垂炎にて虫垂切除施行されている. 平成 14 年 1 月 3 日より右下腹部痛出現. 1 月 5 日腹痛増強にて当院内科受 診. 腹部 CT にて回盲部に腫瘤を認めた。また，大腸内視鏡検査に て虫垂開口部と思われる部位より膿汁の流出を認めた. 保存的療法 にて症状改善せず, 1 月 10 日当科紹介. 腹部超音波検査では盲腸と 連続した管腔構造と,それに連続した low echoic area を認め, 一部 糞石を疑わせる strong echoも認められた．以上より遺残虫垂炎を 疑い, 1月 18 日手術を施行した. 手術所見では, 虫垂切除断端部と 思われる部位を中心として盲腸に炎症性壁肥厚を認め, 盲腸楔状切 除術を施行した. 切除標本では約 $1.3 \mathrm{~cm}$ の虫垂切除断端遺残部に壊 死性粘膜を認め，内部に䔬石を認めた。また，虫垂と連続した盲腸 壁内に膿瘍形成を認めた. 術後経過は良好で, 1 月 26 日退院した. (まとめ)遺残虫垂炎の原因として, 虫垂根部の不完全切除が考えら れた. 近年, 腹腔鏡下虫垂切除術が普及してきているが, 虫垂根部 での確実な切除に注意する必要があると思われる.

PC-1-112 虫垂重積症を伴った早期虫垂癌の 1 例

高野祥直, 菅野智之, 大谷 聡, 見城 明, 寺西 寧, 元 木良一

(総合南東北病院外科)

極めて稀な, 虫垂重積症を呈した早期虫垂癌を経験したので報 告する. 症例は 71 歳男性. 平成 13 年 1 月の大腸癌検診で便潜血陽 性となり近医受診. 大腸内視鏡検査にて上行結腸癌と診断された. 3 月 17 日手術目的に紹介入院. 当院での注腸検査, 大腸内視鏡検 査では, 1 型の盲腸癌と診断され, 4 月 3 日右半結腸切除が施行さ れた. 開腹所見で, 盲腸漿膜倒に虫垂を認めず. 虫垂が虫垂口で盲 腸内に内翻し，いわゆる完全型の虫垂重皘を呈した虫垂癌と診断 された. 肉眼所見では結腸型虫垂癌で, 全周性 5 型, 大きさ 30 $\times 20 \mathrm{~mm}$, 肉眼的深達度不明, $\mathrm{N}(-)$ と診断された. 病理組織検 査でも, 虫垂の漿膜面が腫瘍割面の中心部に確認され, 虫垂原発の 癌による虫垂重積症と確認された. 虫垂癌の組織型は高分化腺癌 で, 深達度 sm, リンパ節転移のない早期癌であった. 虫垂重積症 は, 比較的まれな疾患で, 本邦報告例は文献的には 80 例程である. 原因として, 虫垂の異物, 粪石, ポリープ, 粘液囊腫, 腺腫, 癌な どがあげられている.この中で, 最も多いのは虫垂粘液腫による本 症で, 虫垂重積症の約 4 割にみられる. 虫垂癌が原因となった本邦 報告例は自験例も含め 10 例で, 非常に少ない. 
PC-1-113 虫垂杯細胞カルチノイドの一例

石崎秀信, 井上晴洋, 薄井信介, 日高英二, 吉田達也, 梅 澤昭子，遠藤俊吾，田中淳一，工藤進英 (昭和大学横浜市北部病院消化器センター)

症例は 42 歳男性で, 平成 13 年 5 月 20 日右下腹部痛及び右側腹 部・右腰背部の疼痛を主訴に当院救急外来を受診した. 発熱は 38.8 度, 右下腹部に圧痛を認め, WBC：17.400, CRP：5.74であり, CT 所見で腫大した虫垂を認めた為, 急性虫垂炎の診断にて緊急入院と なった. 5 月 21 日に腹腔鏡下虫垂切除術を施行した. 虫垂は後腹膜 に癒着しており，これを剥離・脱転する際に虫垂の一部が穿破し た. 病理診断では虫垂 goblet cell carcinoid, 深達度 ss であり, かつ 虫垂根部で断端陽性であったため, 追加切除の方針とし，6月 4 日 に開腹下に回盲部切除術・D2 郭清を施行した. 腹腔内に明らかな 遺残は認めなかったが, 腫瘍の性格を考慮し CDDP100mg を腹腔 内投与した. 切除標本では虫垂開口部に約 $2 \mathrm{~cm}$ の範囲で全層に goblet cell carcinoid を認めたが, リンパ節転移を認めず, 根治切除 であった. 現在まで約 9 ケ経過しているが, 明らかな再発・転移 を認めていない. 虫垂杯細胞カルチノイドはカルチノイド腫瘍の中 でも極めて悪性度の高い希な腫瘍であり，本邦報告例はこれまで 61 例である. 今回, われわれは急性虫垂炎で発症した杯細胞カルチ ノイドの一例を経験したので, 文献的考察を加えて報告する.

\section{PC-1-114 Stage IIIa 大腸癌手術症例の検討}

田島秀浩, 角谷直孝, 竹下雅樹, 永井 昇, 松村昭宏, 村 岡恵一, 福島 亘, 廣澤久史, 泉 良平

（富山市民病院外科）

【目的】大腸癌において stage IIIa は壁深達度とリンパ節転移 度の二因子を含んでいる. そこで, stage IIIa を他臓器浸潤のみ の群, リンパ節転移のみの群, および両者を認める群に分類し, 比較検討を行った.【対象と方法】過去 10 年間に当科で経験し た大腸癌手術症例 657 例（結腸癌 449 例, 直腸癌 208 例）を対 象とし, stage IIIa 症例を A 群 : si, ai, $\mathrm{n}(-), \mathrm{B}$ 群 : 深達度 se, $\mathrm{a}_{2}$ までで, $\mathrm{n}_{1}(+), \mathrm{C}$ 群 : si, ai, $\mathrm{n}_{1}(+)$ の三群に分類し, 臨床病理学的諸因子について比較検討した.【結果】 $\mathrm{N}_{1}(+)$ 症 例 232 例のうち $\mathrm{nl}(+)$ は 103 例 $(44.4 \%)$ で, $\mathrm{Si}, \mathrm{Ai}$ 症例 92 例のうち si, ai は 36 例 (39.1\%) に過ぎなかった. 各群の症例 数は A 群 14 例, B 群 137 例, C 群 9 例で, 背景因子に差はな かった. 生存率は結腸癌では差を認めなかったが, 直腸癌では $\mathrm{A}$ 群が $\mathrm{B}$ 群に比して有意に予後不良であり $(\mathrm{p}<0.01)$ ，また， $\mathrm{A}, \mathrm{C}$ 群の再発形式は B 群に比して局所再発が多かった $(\mathrm{p}<$ 0.01).【結語】直腸癌 stage IIIa ではリンパ節転移よりも他臟器 浸潤の有無が予後に影響すると考えられ，n（-）でも si，ai 症例に対しては厳重な経過観察が必要と考えられた.
PC-1-115 Cronkhite-Canada 症候群に大腸癌を併存し た 2 症例

小林久美子, 飯合恒夫, 亀山仁史, 松木 淳, 林 光弘, 山崎俊幸, 岡本春彦, 須田武保, 畠山勝義

(新潟大学医歯学総合研究科消化器・D般外科)

大腸癌を併存した Cronkhite-Canada 症候群 (CCS) の 2 症例を経 験したので報告する. (症例 1) 65 歳, 男性. 主訴は食欲不振, 下疬. 内視鏡にて胃から大腸にかけてポリポーシスを認め, CCS と診断 され，ステロイド治療開始. 下部消化管内視鏡にて Raに $4 \mathrm{~cm}$ 大の lsp 病変を認め, 生検にて adenocarcinoma (well)の診断であった. 腸管の肥厚, ステロイド投与歴 (total：1785mg) より腸管吻合は困 難と考え, Hartmann 手術, 第 2 群リンパ節郭清を施行. 病理組織 所見では adenocarcinoma, ss, ly1, v0 であった（症例 2) 57 歳, 男 性. 主訴は下揦, 味覚異常. 内視鏡にて胃から直腸にかけてポリポー シスを認め, CCS と診断された. Rsに $3 \mathrm{~cm}$ 大の $1 \mathrm{p}$ 病変認め, 生検 にて adenocarcinoma (well) の診断であった為, EMR を施行. 病 理組織所見では adenocartinoma in tubular adenoma, m, ly $(-)$, v (-) であった. (考察) CCS は原因不明の疾患であり, 癌化は無 いとされている.一般に予後は不良とされているが, 我が国では多 くの長期生存例を認めている. このような中で, 当症例のように癌 と併存する症例も増加する事が考えられ, CCSに対しては, 癌の併 存を考慮した注意深い経過観察が重要であると考えられた。

PC-1-116 左腋窩領域にリンパ節転移をきたした $\mathrm{S}$ 状結 腸癌の 1 例

山田理恵子", 加藤博之"), 吉松和彦"), 石橋敬一郎", 岩崎

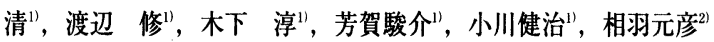
(東京女子医科大学附属第二病院外科 ${ }^{1}$, 東京女子医科大 学附属第二病院病院病理科 ${ }^{21}$ )

大腸癌において腹腔外リンパ節転移はまれであるが遠隔転移と 位置づけられ, 予後不良因子である. 今回われわれは左腋窩リンパ 節転移をきたした S 状結腸癌に, 左腋窩郭清を伴う S 状結腸切除 術を行った 1 例を経験したので報告する. 症例は 45 歳, 女性. 平 成 13 年 6 月頃より左腋㸗の腫瘤を認めるも放置, 8 月近医で貧血 を指摘され, 精査にて S 状結腸癌と診断. 手術目的で当科入院とな る. 入院時左腋窩に硬い腫瘤を触知し, 穿刺吸引細胞診で class5 であったが, 乳房に異常はなかった. 9 月 21 日 S 状結腸切除術 (D3), 左腋窝リンパ節郭清術を施行. 開腹すると大動脈周囲リンパ 節も腫大し, 上方に数珠状につながっていた為, 全郭清は困難と判 断, No216 リンパ節はb1b2.の郭清のみにとどめた. 腋窩には多数 の硬いリンパ節を認め, 乳癌取り扱い規約の Level3 まで郭清を 行った. 手術所見は S, 3 型, N4 (+), P0, H0, M (+) (左腋窝り) ンパ節), Stage4, CurC, 病理組織学的には低分化腺癌, ss, n4, ly $3, \mathrm{v} 1$ で, 腋㸗リンパ節も S 状結腸癌原発单と同様の低分化腺癌 で, 転移と診断された. 術後経過良好で, 10 月 9 日退院, 現在外来 でアイソボリン $/ 5 \mathrm{FU}$ の化学療法施行中で, 再燃は認めていない. 
PC-1-117 直腸内分泌細胞癌と直腸中分化型腺癌の多重 癌の 1 例

中山善文 ${ }^{11}$, 楠田慎一 ${ }^{1)}$, 日暮愛一郎 ${ }^{1)}$, 平田敬治 ${ }^{1)}$, 岡本 好司 ${ }^{11}$, 小西鉄巳 ${ }^{11}$, 永田直幹1)，黑田裕介 ${ }^{2}$, 伊藤英明 ${ }^{12}$ (産業医科大学医学部第 1 外科 ${ }^{1}$, 産業医科大学産業保健 学部 $\left.{ }^{21}\right)$

直腸内分泌細胞癌はきわめて子後不良のまれな腫瘍である. 今回我々は多発性肝転移を伴う直腸内分泌細胞癌と直腸中分 化型腺癌の多重癌の 1 手術例を経験したので報告する. 症例は 52 歳, 男性. 1 年前から残便感, 便柱の狭小化あり, 2 ヶ月前 から血便あり，1 ケ月前から全身倦怠感出現し近医受診. 精査 にて直腸癌の診断で平成 13 年 6 月 27 日当科外来紹介受診. 注 腸造影で Ra に 2 型の直腸癌と Rs に背側からの円弧状の隆起 性病変が認められた. CT で多発性肝転移と胆石を認め, CEA は 22.5 と上昇していた. 入院後, 直腸低位前方切除術, 胆囊摘 出術を施行. a2n3P1H3 stage IV であった. その後の CT で肝転 移巣の急速な增大と腹部大動脈周囲リンパ節の腫大を認めた. 病理の結果, Ra の 2 型病変は中分化型腺癌, a1, ly1, v1, n0, Rs の隆起性病変は内分泌細胞癌, a2, ly2, v1, n3 で, 連続切片で双 方の腫瘍に連続性は認められず多重直腸癌であった. また, 直 腸内分泌細胞癌の免疫染色では synaptophysin, chromogranin A が陽性であった. 直腸内分泌小細胞癌の本邦報告例は, 1984 年の Shimoda らの報告から数えて 39 症例目である.

\section{PC-1-118 直腸癌骨盤内再発の臨床病理学的検討}

福永浩紀, 池永雅一, 山本浩文, 池田正孝, 能浦畺吾, 小 川 稔, 松本 崇, 山田正治, 関本貢呞, 門田守人 (大阪大学大学院病態制御外科)

はじめに; 今回, 我々は, 直腸癌骨盤内再発の臨床病理学的検 討を行った. 対象と方法; 直腸癌術後の症例で, 術前の画像診 断・生検, 術後の病理学的診断にて骨盤内再発と診断した 25 例を対象とした. 結果 ; 初回手術時の病期は stage I, II, IIIa, IIIb, IV が $0,8,12,4,1$ 例. 高分化癌, 中分化癌, 低分化癌, 粘液癌が $11,13,0,1$ 例. 初回手術から再発までの期間は, 1 年以内, $1 \sim 2$ 年, $2 \sim 3$ 年, 3 年以上が $9,11,2,3$ 例であり 80 $\%$ 2 年以内の再発であった. 再発形式は, 周囲軟部組織, 吻 合部, リンパ節, 骨盤内他臓器転移が $14,6,4,1$ 例. 再発が疑 われた理由は臨床症状によるもの 14 例, 腫瘍マーカーなどに よるもの 7 例, 画像診断によるもの 4 例であり, 臨床症状から 再発を疑われた症例が $56 \%$ であった. 初回手術を調査し得た 16 例について検討したところ, 肉眼的遺残, 術中穿孔など手 術操作や手術適応の問題と考えられるものが 7 例 $(44 \%)$ で あった. 結論; 直腸癌の骨盤内再発は 2 年以内の再発が 80 \%であり, 手術操作に問題のあった症例に対しては, 骨盤再発 を念頭においた厳重な follow が必要であると考えられた.
PC-1-119 放射線化学療法が奏効した下部直腸移行上皮 癌の 1 例

渡邊久美子, 関川浩司, 佐久間浩, 滝田賢一, 佐藤尚樹, 畠山優一, 小山善久, 井上典夫, 竹之下誠一

(福島県立医科大学医学部外科学第二講座)

非常に稀な下部直腸移行上皮癌の症例を経験したので報告する. (症例) 54 歳男性. 2001 年 9 月頃より肛門からの出血を自覚し, 近 医を受診. 直腸指診にて下部直腸後壁に腫瘤を認めたため当科紹 介. 注腸検査で $\mathrm{Rb}$ に, 腫瘤像を認め, 大腸内視鏡で肛門縁より 3$4 \mathrm{~cm}$ の部位に 2 型の腫瘍を認めた. 生検標本にて移行上皮癌と診断 された. 膀胱からの浸潤を疑い精查するも膀胱, 尿管に腫瘍病変は なかった: 以上より直腸下部発生の移行上皮癌と診断したが, 手術 を希望しなかったため放射線化学療法を施行した. 1 日 $2 \mathrm{~Gy}$, 週 5 日, 計 40Gy 実施し, 同期間に隔日に F-I 療法 (5-FU500mg/day, Isovorin $25 \mathrm{mg} / \mathrm{day})$ を加えた. その後行った注腸検查, 大腸内視鏡 にて腫瘤の縮小が確認された．そのため $20 \mathrm{~Gy}$ の追加照射を行い退 院となった. (考察) 結腸直腸において移行上皮癌は大変稀な組織型 と考えられる.我々が調べた限りにおいて国内外ともに症例の報告 はない. 患者が手術を希望しなかったため本症例には放射線化学療 法を行ったが, 移行上皮癌が放射線感受性があることから効果的な 治療ができたと考えられる. (結語) 下部直腸原発の移行上皮癌症例 を経験した．本症例においては放射線化学療法が有効であった.

PC-1-120 CHOP 療法が著効した直腸原発 MALT リン パ腫の 1 例

千葉洋平, 白部多可史, 鶴田雅士, 今井達郎

\section{(多摩丘陵病院外科)}

今回我々は, 全身状態から手術を断念し, CHOP 療法を施行, CR を得た直腸原発 MALT リンパ腫の 1 例を経験したので若干 の文献的考察を加え報告する. 【症例】74 歳女性. 便潜血陽性にて 精查目的で受診となった. 注腸造影で直腸 Ra に $5 \mathrm{~cm}$ 大の半球 状の腫瘤影を認めた．大腸内視鏡では表面が比較的滑らかな腫 瘍を認めた. 腹部・骨盤 CT では, 腫瘍近傍のリンパ節腫大を認 め, 直腸原発悪性疾患のリンパ節転移が強く疑われた. 生検鉗子 を用いて腫瘍深部より細胞を採取したところ, HE 染色像, 免疫 組織学的所見から MALT リンパ腫と診断された. 胸部 CT, Ga シンチグラムでは異常を認めなかった. 手術を検討したが, 呼吸 機能の低下が明らかとなり高齢も考慮し手術を断念した. Informed consent のうえ, CHOP 療法を施行した. 3 クール終了時 で内視鏡上腫瘍はほほ消失した. 合計 5 クール施行し現在外来 経過観察中であるが, 遺残, 再発は認められていない.【考察】直 腸原発 MALT リンパ腫は報告例が少なく, 多くは手術療法が第 一選択とされていた. 本症に対する化学療法の有効性について の報告はなく, 今後検討されるべき課題であると考えられた. 